$(-5)(6)=$

N.0. Jow

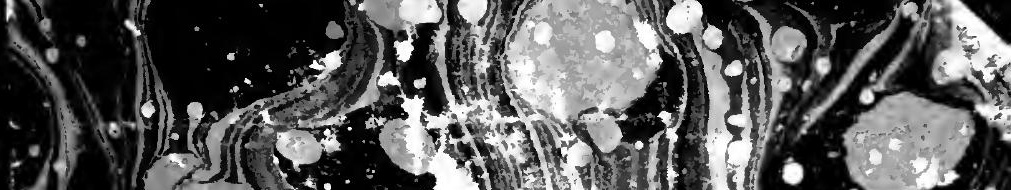
2) $(x), 1)$ -) $7010 \mathrm{c}$ (2)

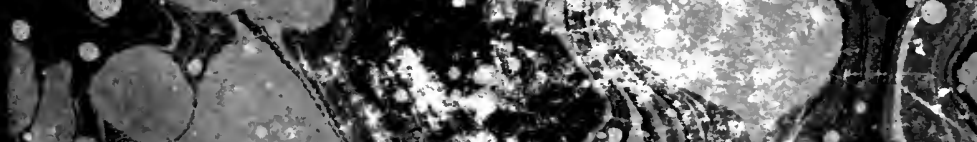

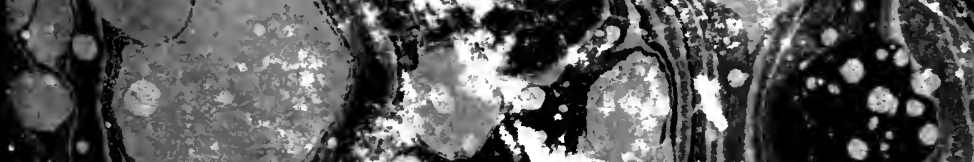
Ihop. 3 ( )

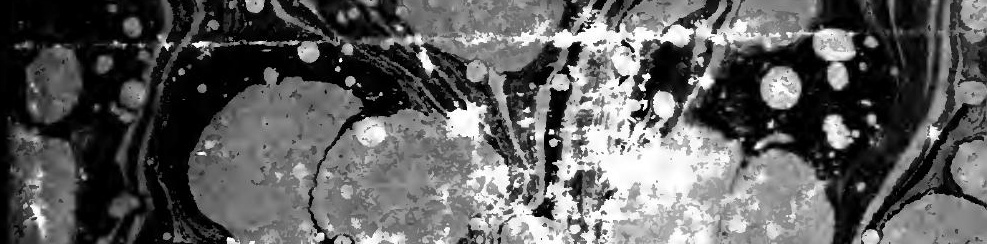
$4(0,2)+2)$

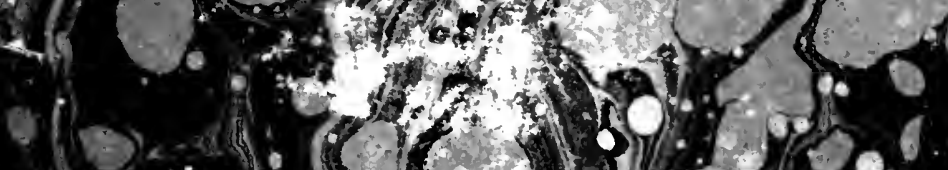

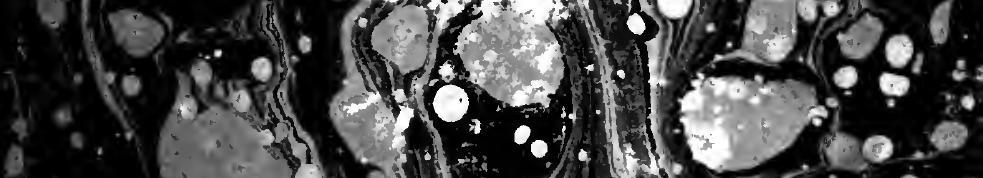





\title{
EUCHARISTICAL ADORATION.
}

\author{
BS THE \\ REV. JOHN KEBLE, M.A.,
}

VICAR OF FURSLET.

"IT pleased Gon the WORD to mite the created Flesh which is of Us without blemish unto Himself: therefore It is adored, with GoD the Word, inasmuch as He hatlı deified It."-Anon. ap. Chrys., ed. Sav., vi. 962.

"Grant, O Lond, that in reading Thy Holy Word, I may never prefer my private scutiments before those of the Church in the purely ancient times of Christianity."-Bishop Wilson, Sacra Privata, p. 135, ed. 1853.

SECOND EDITION.

O X F O R I),

ANI) 377, STHAND, IONDON :

JOHN IIENRY AND JAMES PARKER.

M vecc LIX. 
PLITED HY MESSISS, PAREEK, CORSMARKET, OXFORD. 
y. O Lond Jesus Christ, the same yesterday, to-day, and for ever.

R. Preserve us from being earried about with divers and strange doctrines.

Almighty, everliving Farmen, Who hast promised unto Thy faithful people life by Thine Incarnate Sox, even as He liveth by Thee; Grant unto us all, and espeeially to our Bishops and Pastors, and to those whom Thy Providence hath in any wise entrusted with the treasure of Thy holy doctrine amongst us, Thy good SpIRIT, always so to believe and understand, to feel and firmly to hold, to speak and to think, coneerning the Mystery of the Communion of Thy Sox's Body and Blood, as shall be well-pleasing to Thee, and profitable to our souls; through the same our LOR1 JESUs CHRIST, Who liveth and reigneth with Thee in the unity of the same SpIRIT, One God, world without end. Amen. 



\section{PREFACE TO THE SECOND EDITION.}

I wIsн here to say a few words, by way of explaining why this little book reappears with only such slight changes, as will be found on comparing the present with the First Edition.

Besides correcting a few oversights,-more, however, and less excusable than $I$ could have wished,-those changes are mostly confined to that portion of the work which deals with the intention of the final revisers of the Prayer-book; on which point, as far as I have gone hitherto, all additional researches have tended only to strengthen our case.

I could not be without misgivings, when I found that some of thosc, whom I am bound on all accounts deeply to respect, thought the treatisc incorrect in reasoning, and (what indeed I should most excecdingly deprecate) its conclusions, if not its general spirit, alien to those of the English Church.

I have therefore re-considered it to the best of my leisure and ability; and can only hope that it is not mere selfdeceit which makes me feel unable to plead guilty to either of these very serious charges.

It has been said that the two first chapters of the Lissay are irrelevant,--that they proceed on an ignoratio elenchi,-because they do not, it is conceired, of themselves prove, that our Loord's Person is to be adored as present in the Eucha- 
list by a Real Presence of His Body and Blood,-the Inward Part of that Sacrament. Waiving the question how far the negative is correct, the places there alleged will not, I imagine, seem irrelevant, if taken together they constitute a reasonable presumption in favour of that Presence, and the worship resulting from it: just as the fact, that everywhere in the Holy Scriptures we are encouraged to pay all honour and devotion to our Lord, and nowhere warned against excess in so doing, would constitute a strong presumption in favour of His proper Godhead, though there were no express texts to assert it; and is a strong reason for interpreting doubtful texts and ambiguous sayings of the Church in the higher rather than in the lower sense concerning Him. This is, indeed, all that those two first chapters profess ${ }^{a}$; and if they do carry us so far, I cannot allow that they are irrelevant to the main argument; which, in this aspect, may be stated thus:-

If the general presumption from Scripture and from Natural Piety be in favour of Eucharistical Adoration, then doubtful passages in Scripture, in Fathers and Liturgies, and in our own Formularies, should be construed in that sense. But such presumption does exist, unquestionably, to a very great amount. Therefore such should be our rule of interpretation.

Proceeding to Christian Antiquity, the treatise alleges certain undeniable facts. 1. Writers of high credit in the fourth and fifth centurics affirm it to have been the custom of the whole Church in their time to worship in the Eucharist the Flesh which Christ took of the Virgin Mary. 2. They mention it as a primitive univcrsal tradition. 3. They account for it by the Incarnation, and by the Real Spiritual Presence in the Sacrament. 4. The Christian world, during 
the whole time of which that worship is affirmed, had with one voiee, both in Church and out of Church, been deelaring its faith in such a Presence as no man could believe without adoring b. (This I do not profess to demonstrate, but accept it as demonstrated by Dr. Pusey and others.) So that the historical statement is just what one might expect from the doctrinal: and there is nothing in antiquity to contradict either of them; and very much, as we have seen, both in Scripture and in man's natural heart, to bespeak our favourable acceptance of them.

It is thought, however, that men may safely disregard the historical evidence to the fact of Eucharistical Adoration, (a.) because, as here exhibited, it is comprised in only four or five passages; or, $(\beta$.) because these passages are referred to by Roman Catholics for the same purpose: and as to the doctrinal statements of the first five centuries, coneurring as they do entirely with the historieal testimonies, it is by some replied, $(\gamma$.$) that the Fathers and Liturgies teach a$ Virtual Presence but Real Absence of the Body and Blood of Christ : by others, not so many, $(\delta$.) that there is indeed full testimony to the Presenee, but that the worship does not follow, seeing that His Body and Blood may be present apart from His Divine Person. (є.) Cases (and they are very numerous) to which neither of these statements can be made to apply, are presently disposed of with the remark, That the Aneients were writing rhetorieally, not theologically, and would have expressed themselves otherwise had

b At least in heart; for I have stated in the outset of the argument, and $I$ lope it will be borne in mind all along, that nothing external is necessarily implied; nothing indeed new or strange, nor more than pious Church people (unless they have been embarrassed by theories) habitually practise, though it may be with some. thing of ignorance or indistinctness. No need to start back, as if one were teaching some new thing, insteal of only helping Christians to approve to their own judgments what they have always felt devontly in their hearts. 
they been aware of the errors which should one day arise in the Church. On each of these solutions I will say a few words, just to indicate why they do not appear satisfactory.

(a.) To a public matter of fact, such as the custom of Adoration, four or five contemporary witnesses, circumstanced as those Fathers were, would be held by most historians amply sufficient; unless there were strong counter evidence, or an overpowering degree of intrinsic improbability in their statements; neither of which can here be alleged. All that has been said comes to, "There might have been mole evidence than there is."

( $\beta$.) A moment's thought will shew that the merc use of a doctrine or an interpretation by the Roman Catholics is no reason why we should reject it; unless we are prepared to reject all points in our common Creed, which they prove, as we do, by Scripture and Antiquity.

$(\gamma$ ) The question between a Real and Virtual Presence can only be decided (as far as it depends on Ancient Cousent) by a thorough critical induction of passages. For the groundwork of such a process, and something more, a person may well avail himself of Dr. Pusey's work above mentioned; and the Liturgies, which do not enter into Dr. Pusey's plan, are happily being made accessible through the series in course of publication by Mr. Neale. To these and other like helps the readers of this Essay are referred: the Essay itself, taking generally the doctrine of the Real Presence for granted, tries to illustrate and enforce from it, and from the Prayer-book which teaches it, the moral and devotional duty of Adoration. I have used advisedly the term "Virtual Presence but Real Absence," believing the two phrases to be so connected, that they who limit themselves to the former do in effect teach the latter, however many of them may shrink from owning it to themselves; thereby giving a 
blessed token that their loving hearts believe more than their preoccupied reason discerns in this miracle of mercy. "They feel that they are happier than they know." But this does not hinder the ill effect of such inadequate doctrine upon the average sort of those who teach and hear it.

In order to maintain their view, they are obliged to make out that those sayings of the Fathers, comparatively very few, which seem to deny the Real Presence, are the staple of the whole ancient doctrine. The Eucharistical thoughts and words of the great theologians, the very Anaphore of the primitive Liturgies, are to be toned down till they are in unison with that one saying of S. Augustine, "Sacraments, from their resemblance to the things of which they are the Sacraments, receive for the most part the names even of the things themselves;" and accordingly, whenever our Lord's Body and Blood is so spoken of as to imply a Real Presence, we are to understand it, if we can, of the outward sign only, called by the name of the Inward Part: which appears to $\mathrm{me}$ no more reasonable than for a Socinian to insist upon such a text as "I have made thee a God to Pharaoh," by way of warrant for explaining away all the declarations of our Lord's proper Divinity. It is a sad habit of thought for a theologian to train himself up in,that of instinctively adopting, out of various expositions, the most earthly and least supernatural. The least harm that can be said of it is, that it is just contrary to what we should have looked for from the known analogies of God's successive dispensations; it is more in harmony with Jewish than with Christian interpretations of the Old Testament. I fear that the Church is too likely to experience more and more of this.

$(\delta$.$) In the face of such a tendency on the one hand, and$ of the pressure from Rome on the other, it is neither sur- 
prising nor uninstructive to find persons learned in the Liturgies especially, unable to hide their eyes from the unquestionable and unquestioning acknowledgment of a Real Presence there every where to be found, but cqually unable to reconeile themselves to the inevitable corollary of that tenet, Adoration. And so they are driven, as I have said, to imagine such a Real Presence of our Lord's crucified Body and Blood shed, as shall not involve a peculiar Presence of His Divine Person. An imagination which every

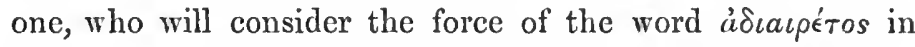
Church decrees on our Lord's Incarnation, will allow to be untenable, since in logical consequence it could not stop short of plain Nestorianism.

(є.) There remains the common and popular allegation, that the Fathers (to whom must be added the compilers of the Liturgies) spoke rhetorically, not exactly, and would not have so taught had they known what was coming. It is not speaking too strongly to say, that this statement, in order to be effectual, must dispose of nearly the whole of what Antiquity has left us on the subject. Applied on such a scale, it sounds ( $\mathrm{I}$ do not say is meant to be) very disparaging to the Fathers and to their authority. In itself it is most improbable. Considering the endless variety of individuals and of circumstanees, comprehended in the one term, Christian Antiquity, it was very unlikely that with one consent, being left to themselves, all Churches and all writers should err in the same direction-by over-statement.

Compare, in this point of view, the patristical remains with the series of our own standard divines since the Reformation. You will find in those ancients little or nothing, as among us on this topic, of variety arising from school or section,-from the fancy, temper, or feelings of the several men. The plain inference is, that the Church, they thought, had scttled the point for them. 
We cannot (as has been alleged) account for this uniform tenor of their language, by the supposition that in those days there was no tendency to deny or forget the Real Humanity of our Mediator. For all through those ages,from the Docetæ to the Monophysites, from S. John to the Fourth Ecumenical Council,- the Church had to deal distinctly with that particular phase of false doctrine. If the idea of a Real Substantial Presence does indeed contradict the truth of Christ's Body, ccrtainly the times of those dreamy Oriental heresies required especial care in the Church, not to encourage that idea by glowing language, as in S. Chrysostom and the Liturgies.

And here it must be asked, Have people seriously considered what a thing it is to set down the Prayer-books of the ancient Church as incorrect vehicles of sacred truth; to separate, in this case, the "Lex Credendi" so entirely from the "Lex Supplicandi?" It is just what gave so great offence eight or ten years ago, when the doctrine of Baptism was disturbed by the sentence of the Privy Council in a certain cause. Is it not indeed somewhat shocking, for a person saying his prayers to be told that he is not to understand them exactly as they spcak? that in the highest act of Divine communion, both God's words spoken to him, and the words put into his mouth by the Church whereby to pour out his devotion to God, are to be taken as it were at a discount? that instead of lifting up his belief and feeling to his prayers, the truth requires him to lower his understanding of the prayers to something else, which ought to be his feeling and belief? Yet so it was, according to this hypothesis, with all Christians who at any time have worshipped with the ancient Church in her Liturgies: to say nothing of our own. They have had to kecp themselves on their guard, lest they should be misled by the Formularics in which they were joining with the whole Chureh. Would not S. Chryso- 


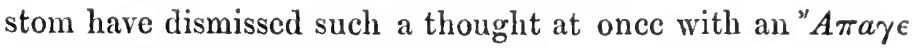

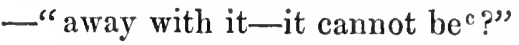

But the mischief goes even deeper, if possible, than this. If on this one doctrine the Fathers and the whole undivided Church, not excepting the great Ecumenical Councils, are to be regarded as habitually overstating the truth,-either unadvisedly, in a kind of enthusiasm, or (for so it has been stated) advisedly, by way of counteracting the irreverence to which heathen converts had been accustomed in celebrating sacrifices,-who shall warrant us that the same authorities are to be trusted, even in their general consent, on other doctrines and interpretations coming under dispute? And what then becomes of the Consensus Patrum, the rule of primitive Tradition, hitherto supposed to be accepted by our branch of the Church, in contradistinction to all developments, as God's special gift for helping us to the right and scriptural conclusion on every point needful to the integrity of the Gospel of our salvation? Here is an absolute unsettling of the standard of faith, especially as between us and Rome. If we should say, "The ancients mistook our Lord's meaning when He said, "This is My Body ;' or however, knowingly or unknowingly, they promulgated a mistaken interpretation of it ;" why might not a Romanist say the same of "On this Rock I will build My Church?" or of "The fire shall try every man's work ?" why not some Calvinist or Zuinglian of "Ye must be born again of water and of the Spirit?" why not some bolder

c The same topic has been applied to the construction of the Scottish Communion Office: which is supposed to negative the Real Presence, because, in common with most of the normal Liturgies of antiquity, it places the Offering before the Invocition. But this argument assumes what ought to be proved,-that the word $\pi \rho \circ \sigma \phi \epsilon ́ \rho \rho \epsilon \nu$ in the Liturgies must be limited to that particular moment in the Service in which it first occurs: unsuitably, as it seems to me, to the natural force of the word in such a case, and also to the fact that the word is repeated again and again after the consecration is undoubtedly completed. 
speculator, of the Nicene Creed itself, or of the Inspiration of the very Scriptures of God? No language, as it seems to me, can exaggerate the evil tendency of all this, especially under present circumstances. In itself, though not so intended, it is far more undutiful than demurring to the authority of this or that Anglican divine; or even (should it so chance) of all. For it is disturbing the whole basis of the Anglican system; it is cutting our cables and setting us all adrift, each one to find his own separate course as he may.

We must claim, therefore, for our mother the Church of England, as well as for each of her sons, however unworthy, to have whatever is ambiguous in her doctrinal sayings interpreted in the sense most agreeable to primitive Antiquity; Holy Scripture, of course, being paramount over all. And we may feel sure that such interpretation, though not, perhaps, so put forth as to exclude every other, was intended at least to be tolerated within our pale.

The fourth section of the following Essay is an attempt to apply this principle to the Rubric touching Adoration at the Holy Communion; and the drift of the quatations there made from Anglican divines, more or less concerned in the adoption of that Rubric, is simply to shew that, at the very least, thcy could not have intended to exclude from the Church of England and her ministry persons adoring Christ as the Inward Part of that Sacrament. This has not always been adverted to by objectors. They have cited passages from some of the revisers themselves, or from others of like authority, really or apparently taking the opposite view, as if such citation were fatal to the argument: whereas the most that can be inferred from both sorts taken together is, that the matter was not understood to be positively and expressly ruled either way. And the fifth section assigus a reason why such "neutrality" (so to call it) should not be regarded as 
damaging our claim to be a true living portion of the Catholic Church.

Under these circumstances, I see no disingenuousness in adopting words, from Ridley (e. g.) or any other, to express one's own view, without stopping to enquire whether, on other occasions, the same author might not have employed different or even contradictory language.

But, indeed, when we have deducted from the testimonies of Anglicau writers alleged against us, such as in reality touch only (1.) Transubstantiation, or (2.) the notion of a gross carnal Preseneed, or (3.) the Ubiquity maintained by some Lutherans, or (4.) the necessity of believing not only in the fact but in the mode of the Real Presence ("whether Trans, Sub, Con," \&c.), or (5.) the Adoration of the outward Elements: and when we have duly weighed those many sayings of theirs, both controversial and devotional, which tell entirely on our side; the remainder of difficulties we have to deal with in that kind will be found in comparison very moderate; nothing, nothing at all, to the work we should have in reconeiling any other doctrine than ours with the Liturgies and standard writers of the holy Church from the beginning. This is our conviction, only the more confirmed when we come to examine carefully the Catence put forth from time to time against us.

But be our Anglican authorities many or few, nay, were there (as we have been lately told) no instance at all, since the last Review, of an English Divine teaching exactly the tenets now so keenly opposed, we shonld still have a claim to be tried, not by any partial development, domestic or foreign, but by our own Formularies, interpreted by Seripture and Antiquity. And if those standards did not con-

d I may perhaps be excused for exemplifying this by the expression sometimes quoted from the "Chris- tian Year:" "present in the heart, not in the hunds :" ce. S. John vi. 63; 1 Cor. xv. 50. 
demn us, we might justly feel ourselves acquitted before God and man.

Such I believe to be our position, such our appeal. I will venture to add one word more on the real extent of the question.

Unless I am greatly mistaken, the real point at issue in most of the controversies which have troubled us all along in the Reformed English Church, might be expressed in words like the following:- "Is the Church, mingled as we see it of good and bad, a supernatural body, separated off from the world to live a supernatural life, begun, continued, and ended in miracles-miracles as real as any of those which befel the Israelites in the wilderness - as real, but infinitely more gracious and awful? or is it only a body providentially raised up to hold the best and purest philosophy-helped as all good things are from above, but in itself no more than the heroical and Divine phase of this present life?" It is plain at first glance which side of this alternative brings with it the more intense obligation to holiness, and represents sin as "more excceding sinful;"-which, therefore, would be most hated and disparaged by the Hater of God and goodness: unless, indeed, he can persuade those who hold it to contradict it in their lives. It is plain also that the doctrine of the Real Presence in the Holy Eucliarist is strictly in unison with the supernatural view; whereas that of a Virtual Presence and Real Absence might be accepted by one who believed that miracles invisible, as well as visible, have entirely ceased.

Here is a prima facie reason why religious and reverent persons should be slow to accept that or any other theory which interferes with simple acquiescence in the words of Scripture and of the ancieut Chureh : and here is also (if possible) a yet stronger reason why those who profess such acquiescence should be more and more on their guard against 
all that is unmeet for His Presence,-more and more fearful as they "enter into the cloud."

So be it: and may our good Lord forgive whatever may have been here or elsewhere written, said, or thought unworthily of this His most holy and ineffable Mystery; and may $\mathrm{He}$ grant this to be the last time that the present writer shall have to deal with It in a controversial way!

\section{HuRstex,}

Conversion of St. Paul, 1859. 


\section{ON EUCHARISTICAL ADORATION;}

OR, THE WORSHIP OF OUR LORD AND SAYIOUR IN THE SACRAMENT OF HOLY COMIIUNION.

\section{CHAPTER I.}

PROMPTINGS OF NATURAL PIETY.

$\S 1$. Thе object of this Essay is to allay, and, if possible, Снар. I. to quiet, the troublesome thoughts which may at times, and now especially, occur to men's minds on this awful subject, so as even to disturb them in the highest act of devotion. For this purpose it may be well to consider calmly, not withont deep reverence of heart, First, what Natural Piety would suggest; Secondly, what Holy Scripture may appear to sanetion; Thirdly, what the Fathers and Liturgies indieate to have been the practice of the Primitive Church; Fourthly, what the Church of England enjoins or recommends.

\$2. For the first: is it not self-evident that, had there been no abuse, or error, or extravaganee conneeted with the practice, all persons believing and considering the Real Presence of our Lord in Holy Communion, in whatever manner or degree, would in the same manner or degree find it impossible not to use special worship? - the inward worship, I mean, and adoration of the heart: for that, of course, is the main point in question; the posture and mode are secondary and variable, and may and must admit of dispensation.

The simple circumstance of our Lord Clrist declaring IIimself especially present would, one would think, be enough for this. Why do we bow our knces and pray, on first enter- 
Cinap. I. ing the Lord's house? Why do we feel that during all our continuanee there we should be, as it were, prostrating our hearts before Ilim? Why is it well to breathe a short prayer when we begin reading our Bibles, and still as we read to recollect ourselves, and try to go on in the spirit of prayer? And so of other holy exereises: in proportion as they bring with them the sense of IIis peculiar presence, what can the believer do but adore? I firmly believe that all good Christians do so, in the Holy Sacrament most especially, whatever embarrassment many of them may unhappily liave been taught to feel touching the precise mode of their adoration.

And this may well be one of the greatest consolations, in the sad controversies and misunderstandings among which our lot is cast. It is as impossible for devout faith, contemplating Christ in this Sacrament, not to adore Him, as it is for a loving mother, looking earnestly at her child, not to love it. The mother's conseiousness of her love, and her outward manifestation of it, may vary ; seruples, interruptions, bewilderments may occur; but there it is in her heart, you cannot suppress it. So must there be special adoration and worship in the heart of every one seriously. believing a special, mysterious presence of Christ, God and man, expressed by the words, This is My Body.

\$3. I say a special adoration and worship, over and above what a religious man feels upon every occasion which helps lim to realize, what he always believes, that God is "about his path, and about his bed, and spieth out all his ways;" that in IIim he "lives, and moves, and has his being." And this for very many mysterious and overpowering reasons. I will specify threc, the most undeniable and irresistible. First, the greatness of the benefit offered; next, its being offered and brought home to caeh one personally and individually; thirdly, the deep condescension and humiliation on the part of Him who offers the benefit.

\$ 4. When Joseph went out over all the land of Egrpt, "they eried before him, Bow the knee." When Moses delivered the first message from God to the Israelites in Egypt, eoncerning their deliveranee, and the sccond message, con- 
cerning the Passover, "the people bowed their heads and Cuar. I. worshipped." Would it not have been very strange, if, when the great promises were realized before their cyes, and they actually saw the token of the Lord's Presence, the fire coming down and consuming their first offering, - that fire which continued until it was quenched by their sins before the first captivity, - they lad scrupled to own His Presence by like adoration? They did the same, and much more, when Aaron, for the first time after his consecration, "lifted up his hand toward the people and blessed them, ... and the glory of the Lord appeared unto all the people. And there came a fire out from before the Lord, and consumed upon the altar the burnt-offering and the fat: which when all the people saw, they shouted, and fell on their facesa." There was no one at hand to say to them, "Take care: people will call it fire-worship." And just in the same way did they acknowledge the finishing of the old dispensation by the building of the Temple. When Darid had completed his preparations, he said to all the congregation, "Now bless the Lord your God. And all the congregation blessed the Lord God of their fathers, and bowed down their heads, and worshipped the Lord and the king ${ }^{\mathrm{b}}$." When, upon the day of consecration, "Solomon had made an end of praying, ... and when all the children of Israel saw how the fire came down, and the glory of the Lord upon the house, they bowed themselves with their faces to the ground upon the parement, and worshipped, and praised the Lord.". "The outward act of worship was more lowly, and no doubt in religious hearts the inward adoration was deeper and more fervent, as the mighty blessing made its approach more manifest.

$\S 5$. So, and much more, in the Christian Church. If we kneel, and bow the knees of our hearts, to receive a blessing in the Name of the Most Iigh from His earthly representatives, Father, Priest, or Bishop, how should we do other than adore and fall prostrate, inwardly at least, when the Son of Man gives His own appointed token that He is descending to bless us in His own mysterious way? And with what a blessing! - "the remission of our sins, and all other benefits of II is

- Tevit. ix, 22-24.

b 1 Chron. xxix. 20.

c 2 Chron. vii. 1, 3. 
Crap. I. Passion !" Mis Flesh, which is meat indeed, and IIis Blood, which is drink indeed! mutual indwelling between Him and us; we living by $\mathrm{Him}$, as He by the Father! Surely these are gifts, at the very hearing of which, were an Angel to come and tell us of them for the first time, we could not choose but fall down and worship. And now it is no Angel, but the Lord of the Angels, incarnate, coming not only to promise, but actually to exhibit and confer them.

\$6. Further, the Eucharist is our Saviour coming with these unutterable mysteries of blessing, coming with His glorified Humanity, coming by a peculiar presence of Ifis own divine Person, to impart Himself to each one of us separately, to impart IIimself as truly and as entirely as if there were not in the world any but that one to receive Him. And this also, namely, the bringing home of God's gifts to the particular individual person, has ever been felt by that person, in proportion to his faith, as a thrilling call for the most unreserved surrender that he could make of himself, his whole spirit, soul, and body: i. e. of the most unreserved Worship.

Look at the saints of God from the beginning. God made a covenant with Abraham, He promised to give him a son of Sarah, and both times Abraham "fell on his faced." Mis servant Eliezer "bowed the head and worshipped," when he fornd that he was miraculously guided to the person whom God had chosen to be Isaac's wife; and again, when her kinsmen had consented to the marriage ${ }^{\mathrm{e}}$. God descended in the cloud on Mount Sinai, and stood with Moses on the mount, in token that he liad found favour in His sight, and IIe knew him by name: Moses "made haste, and bowed his liead toward the earth, and worshippedf."

The captain of the Lord's host appeared unto Joshua, and Joshua "fell on his face to the earth, and did worshipg." The angel of the Lord went up in the flame of Manoah's altar, and Manoah and his wife looked on it, and "fell on their faces to the ground h." When young Samuel was solemnly "lent to the Lord," Eli performed a solemn act of adoration, and IIanuals accompanied it with an adoring

a Gen. xvii. 3, 17.

e Gen. xxiv. 26, 52.

' Exod. xxxiv. 8 .

g Josh. v. 14.

h Judges xiii. 20. 
hymni. The Shunammite, when her child had been raised by Cusp. I. Elisha, "fell at his feet, and bowed herself to the ground k."

$\S 7$. If we go on to the New Testament, and take a few instances out of many, we shall still find that it is the nearness as well as the greatness of the blessing which prompts the special worship or thanksgiving. "Whence is this to me, that the mother of my Lord should come unto me?" "Mine eyes have seen Thy salvation." The leper worshipped IIim, saying, "Lord, if Thou wilt, Thou canst make me clean. And Jesus put forth His hand and touched him." On His walking on the sen, and quieting the storm, after the miracle of the loaves, those who were in the ship came and worshipped Him; so did Jairus, so did the woman with the issue of blood: some of them before, some aftcr the mercy received. So did the woman of Canaan; so the father of the demoniac, after the transfiguration; so the poor slave, orerwhelmed with debt, in the parable of the unmerciful servant; so the mother of Zebedee's children, asking the great wish of her heart; so the holy women, holding Him by the feet, when, being risen, He met them, and said, All hail! so the eleven, meeting IIim by appointment in Galilee. So S. Peter, after the draught of fishes, "fell down at Jesus' kneesl," the more overpowered by the greatness of the miracle, because of the nearness of Him who wrought it; coming into his boat, and directing him where and when to cast the net. So Magdalene, drawn to Him by His presence in the Pharisee's house; so the grateful leper, turning round to Him before He was out of sight; and the eager, rich young man. So Zaccheus, at His coming into his house; so the blind man in S. John ix., "'Thou hast both seen Ilim, and it is He that talketh with thee' ... . and he worshipped Him." So S. Thomas, on His specially addressing him; (for invoking Him as his Lord and God was surely an act of worship ;) so Cornelius to S. Peter; so the jailor to S. Paul and Silas; so S. John to the Angel.

\$8. But three eases there are, which bring out this law of devotion (so to call it) in a peculiar and very wouderful way.

11 Sau. ii. 1.

k 2 Kings ir. 37. ('f. 2 Chron. xx. Is ; Datl. ii. 19.

I s. Jauke v. 8. 


\section{The Magnificat has the Tone of Eucharistical Worship.}

Cuap. I. To Mary of Bethany it was said, "The Master is come, and calleth for thee ;" for thee in particular,--for thee by name : what else can Mary do but hasten and throw herself at Jesus' feet? Not so Martha, who had not been sent for. And again, either of the same holy woman, or of another very like her, we read, "Jesus said unto her, Mary:" it was that, His calling her by name, His coming to herself personally and individually, which had the thrilling effect upon her. She had heard before that He was risen,--she had heard of Him "by the hearing of the ear," - but now she heard Him actually speaking, and speaking to her; and so her eye, which before only saw without resting on Him, came clearly to discern Him. It was the personal application to her by name which drove away for ever her melaneholy dream that IIe was absent, and caused her to turn herself and cry out "My Master!" with an adoring voice and gesture, as the context shews; for the saying, "Touch Me not," implies an attempt on her part to embrace IIis knees, or hold Him by the feet, or some such action: and even if it had not been written, who could have loubted it?

And may we not here, too, remember that other Mary, her whom all generations shall call Blessed, when she not only saw and heard the Angel declaring the message of salvation to her, and to us all, but knew in herself that the Holy Ghost was come upon her, and the Power of the Highest overshadowing her, and that the Holy Thing that should be born of her was to be called the "Son of God?" What her feelings were we partly know by that hymn in which, as wc may reverently believe, she even now joins with the Church continually: which hymn is surely as perfect an act of adoration as ever was performed on earth by any but her divine Son IIimself. We know that her Mugnificat begins with owning the Lord and God as her Saviour; with amazement that He had regarded "the lowliness of Ilis handmaiden;" that He had marked her out for a perpetual blessing, and had done to her great things. In respect of the Inearnation itself, then, it was not only the immensity of the Gift, but its inconccivably near approach also to the Receiver, which she was taught of the Iroly Ghost adoringly 
to acknowledge. Why or how should it be otherwise in re- Cunp. I. spect of that which divincs have truly called " the extension of the Incarnation,"-the participation of the Incarnate One by His true members, in and through the spiritual cating and drinking of His present Body and Blood?

§9. Thus it would appear that God's holy Word from beginning to end abounds in examples to sanction those natural instincts of the devout and loving heart, which prompt to deeper and more intense adoration, in proportion to the greatness of the gift, and the directness with which it comes siraight to the receiver from Almighty God.

Now the gift in the Holy Eucharist is Christ Himself-al good gifts in one; and that in an immense, inconceivable de. gree. And how ean we conceive even Power Almighty to bring it more closely and more dircetly home to each one of us, than when His Word commands and His Spirit enables us to receive Him as it wcre spiritual meat and drink? entering into and penetrating thoroughly the whole being of the renewed man, somewhat in the same way as the virtue of wholesome meat and drink diffuses itself through a healthful body : only, as we all know, with this great difference, (among others,)that earthly meat and drink is taken up and changed into parts of our earthly frame, whereas the work of this heavenly nourishment is to transform our being into itself; to clange us after His image, "from glory to glory," from the fainter to the more perfect brightness; until "our sinful bodies be made clean by His Borly, and our souls washed through Ilis most precious Blood; and we dwell evermore in Him, and IIe in us:" "we in Him," as members of "His mystical Body, which is the blessed company of all faithful people ;" "He in us," by a real and unspeakable union with His divine Pcrson, vonchsafed to us through a real and entirely spiritual participation of that Flesh and Blood which $\mathrm{He}$ took of our Father Adam through the Blessed Virgin Mary; wherewith He suffered on the Cross, wherewith also He now appears day and night before llis Father in heaven for us. So that a holy man of our own Church was not afraid thus to writc of this Sacrament:- 
"By the way of nourishment and strength

Thou creep'st into my breast,

Making Thy way my rest,

And Thy small quantities my length,

Which spread their forees into every part,

Meeting sin's force and art.

"'lhy grace, which with these elements emes,

Knoweth the ready way,

And hath the privy key,

Opening the soul's most subtle rooms m."

$\S 10$. The sum is this. Renewed nature prompts the Christian, and Holy Scripture from beginning to end encourages him, to use special adoration to Almighty God at the receiving of any special gift;-adoration the more earnest and intense as the gift is greater, and the appropriation of it to the worshipper limself more entire and direct. So it is with all lesser, all partial gifts; how then should it not be so when we come to the very crown and fountain of all, that which comprehends all the rest in their highest possible excellency, and which is bestowed on each receiver by way of most unspeakable participation and nnion,- that gift which is God Himself, as well as having God for its Giver? "Christ in us," not only Christ offered for us; a " divine nature" set before us, of which we are to be made "partakers." Must we cease adoring when $\mathrm{He}$ comes not only as the Giver, but as the Gift; not only as the Priest, but as the Victim; not only as "the Master of the Feast," but as "the Feast itself" ?" Nay, but rather this very circumstance is a reason bcyond all reasons for more direct and intense devotion.

$\S 11$. This brings us to the third circumstance, mentioned above as an obvious motive of adoration in the Holy Eucliarist. For consider, - to take the lowest ground first, - when men are receiving a favour from a superior, is not a sense of his condescension a natural ingredient in their loving acknowledgments? and if there is any thing generous and

n: G. Horbert's Remains, p. 99, ed. (1)

\footnotetext{
" Bp. Taylor, Holy living: Works, iv. 310, Helere's culicion.
} 
grateful in their hearts, do they not honour and revere him Снар. I. the more for every suffering, humiliation, debasement, indignity which he may have incurred in doing them good? and can they well endure to hide and repress their venerntion for him? are they not the more bent on avowing it, the more they see him slighted by others, possibly on this very account, that he had not spared so to demean himself for their sake?

Caleb "stilled the people before Moses," when the spies were setting them against $\operatorname{him}^{\circ}$. Joshua was jealous for Moses' sake, when some appeared to be prophesying without commission from him ${ }^{p}$. It is plain that their loyalty to him was quickened by the reproach they saw him enduring. So all the dark feelings and speeches of the unhappy Saul concerning David, served but to settle Jonathan's heart in loving and honouring him more than ever. So Shimei's cursing David in his affliction kindled the zeal of his soldiers and servants.

And our Master, when He was with us in the flesh, more than once gave token of especial approbation and blessing to those who confessed Him the more unreservedly for the wrong that was done Him; as to the sinful woman, who, unconsciously or not, supplied the Pharisee's discourtesy by a washing, anointing, and salutation of her own; to Simon Peter, speaking out before the rest, to own as the words of eternal life those sayings about Holy Communion, whieh had just driven away many of the disciples in disgust; and very significantly to the man born blind, when he in dutiful and pious gratitude had stood up for Christ, his Restorer, against the Pharisces, and had incurred their scorn and hatred. "Thou wast altogether born in sin, and dost thou teach us? and they cast him ont. Jesus heard that they had cast him out; and when He had found him, He said unto him, Dost thou believe on the Son of God? he answered and said, Who is He, Lord, that I might believe on Him? Aud Jesus said unto him, Thou hast both seen Him, and it is He that talketh with thee. And he said, Lord, I believe. And he worshipped IIim 9." 'The Pharisees' reviling of Christ,

\footnotetext{
- Numbers xiii. 30.

"Numbers ai. 2s.

7. S. dohn is. $34-38$.
} 


\section{0}

The Penitent Thief a Model of Eucharistical Worship.

Cuar. I. and of himself for Christ's sake, led lim not only to belief, but to adoration.

And what shall we say of the Thief on the Cross? It may appear by the tenor of the sacred history, that the providential instrument of his conversion was the revilings of the crowd and of his fellow-malefactor,-in which he himself at first ignorantly joined,-so meekly and majestically borne by the holy Jesus. When he saw that, he pereeived at once that "This Man hath clone nothing amiss;" and he became the first to know and own Christ, "and the power of His resurrection, and the fellowship of His sufferings, being made conformable unto His death $\mathrm{r}$." The deep veneration he had conceived for our Lord, as for an innocent Man receiving the due reward of such wicked deeds as his own, was rewarded with an adoring faith in I Him as Lord and Judge of the whole world; and he became the first example of those who should be saved by the blessed Cross. And beholding his Lord's glory through the veil of His extreme humiliation, and taught from above to understand that for that very humiliation's sake he was to surrender himself entirely to Christ,-to worship Him with all the powers of his soul,he became also a pattern for all who would be wortly communicants. For what is that which we remember specially, and on which we fix our mind's eye in Holy Communion, but the same which he then saw with his bodily eyes?-the Body and Blood of Christ, i. e. Christ IIimself, offered up by Himself for that thief and for each one of us? And if he worshipped, and was blessed, why not we?

We seem to have been drawn up unawares, by this enumeration of examples, from the contemplation of a high moral sentiment to that of a cardinal principle in the kingdom of heaven; for such undoubtedly has ever been the rule of acknowledging Christ's Incarnation, and all His condescensions and humiliations consequent upon it, by special and express acts of homage and worship, inward and outward, according to the time and occasion.

But this topic may better be referred to the second and 
The Antecedent Presumption is in favour of Worship. 11 third heads of our proposed enquiry,-What are the more Crap. I. direct bearings of Iloly Scripture, and ancient Church tesmonies, on the practice of worshipping Christ in the Eucharist?

\section{CHAPTER II. \\ SUGGESTIONS OF HOLY SCRIPTURE.}

§ 1 . Arter what has been alleged, it will not, I think, be assuming too much, if we turn to those passages of our Bibles which more immediately relate to the Eucharist and the great theological verities connected with it, in the expectation of finding the worship of Christ in that Sacrament rather enjoined than discouraged; seeing that therein are combined and concentrated, in a manner and degrce past liuman imagining, the several reasons and occasions of special worship, such as, in minor instances, natural piety points them out to us, and as they are everywhere recognised by Holy Scripture and the Church. There is (1.) a peculiar Presence of the Most High ; (2.) bringing with it an awful, an infinite blessing; (3.) appropriating it, moreover, to each one of us in a way inconceivably near and intimate; and (4.) with a measure of condescension and humiliation on His part, sucl as could not have entered into the heart of man to conceive. Surely if, notwithstanding all this, our Lord's will is that we should not so adore Him, we might expect to find somewhere a distinct prohibition of the practice. The onus probandi lies upon those who would restrain us. We may require them, in legal phrase, to "shew causc" from the Word of God, as understood always, ererywhere, and by all, why we should do violence to so many instincts of our nature. As Bishop Taylor has taught us to ask, "If Christ be there, why are we not to worship?" I say again, According to all sound rules of argument, it is rather our right to eall upon those who censure the practice to cite some text forbidding it, than it is theirs to call upon us for one cxpressly enjoining it.

It has been repeated over and over again, that neither our 
Chap. II. Lord in the words of institution, nor $\mathrm{S}$. Paul in his inspired comment on them, has said anything about worshipping Christ there present "under the form" (or "outward part") "of Bread and Wine;" and thcrefore, that to abstain from such worship is the safer way. "If it be not commanded, it is virtually forbidden." Perhaps the foregoing consileritions may lead some to invert the argument, and say rather, "If not forbidden, it is virtually commanded."

I proceed to point out in Holy Scripture what appears to me a very strong additional argument for the practice,a complete justification, even if it do not amount to an implicit recommendation of it.

\$2. Carrying on the idea with which the former section ended, may we not say, that throughout Holy Scripture, as afterwards throughout the traditions of the Catholic Church, is disccrnible an evident anxiety (so to speak) to preserve, and encourage, and impress on all believers this portion especially of the sacred doctrine of the Incarnation, That "the Manhood is taken into God?" the liuman nature abiding in our Lord's Pcrson, true and entire, from the very moment of His Incarnation; and thenceforth eternally receiving from the Divine Nature, to which it is inseparably united, all such properties and perfections as it might enjoy without losing its reality and ceasing to be human. The manifestation, indeed, of these properties and perfections,the "Beams of Deity,"-restrained and enlarged themselves according to the exigencies of the marvellous work in progress, known only to the great Ruler thereof; but in deed and in truth the Communication itself of the properties of the higher nature to the lower, (to use a comparatively late ecclcsiastical form,) was complete within the limit abovementioned, from the very moment that the Second Person of the Trinity became Man.

§3. With regard especially to that property to which the present enquiry relates, - the Epistle to the Hebrews expressly declares, "When He bringeth in the First-begotten

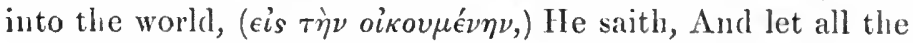

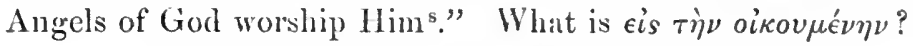

- Heb. i. 5 ; from P's xevii. 7, and Deut. xxxii. 43. IXX. 
"Into the created and inhabited world:" (such is the con- CaAp.II. stant use of the word in Holy Scripture). Therefore the saying, "Introducing the First-born into the world," literally means "causing Ifim to become one of the creatures, one of the inhabitants of the world which God had made;" as He lescribes Himself, "These things saith the Amen, the faithful and true witness, the beginning of the creation of Grod $^{t}$;" or as the IIoly Ghost describes Him by S. Paul, He is "the Image of the invisible God, the First-born of every creature ";" "the First-born among many brethrenx ;" the Firstborn, not in time, but in rank, and in the counsel of God.

Of course, when our gracious Lord began to be of the number of God's creatures, i. c. at the time of His incarnation and birth, He began to be the First-born in this sense. To that moment, and to no other, we may with some confidence affirm, the Apostle carries us back,--as the prophet David, whom he by the Holy Ghost is interpreting, carries us forward,-in the words, "And let all the Angels of God worship Him." The prophecy we know was literally fulfilled: to the Hebrew Clristians, to whom the Apostle was writing, it was matter of well-known history. At the very time that the blessed Virgin Mary brought forth her Firstborn Son, the Angel appeared to the shepherds with the good tidings of great joy; but the multitude of the heavenly host, with their full hymn of praise, did not appear until the words of deeper humiliation were added, "Ye shall find the Babe wrapped in swaddling elothes, lying in a manger." A thing which has been often observed, and which is surely much to our present purpose : it has a doctrinal as well as a moral meaning. Read by the light which is thrown back upon it by the Apostle's saying to the Hebrews, it looks like a proclamation from the Great King, This is He whom I delight to honour, "worship Him all ye gods," all that is called God in heaven and in earth; let the highest of created beings adore Him with a special worship by rcason of His nnspeakable humiliation, now that He is made man, "wrapped in swaddling clothes, and laid in a manger ;" let them understand that on this day the Father of all by the

$$
\text { 'Rev. ii. 1.4. "Coloss. i. 15. } \quad \text { som. riii. } 29 .
$$


Crap. II. IIoly Gliost hath become the Father of the Man Christ Jesus, in that sense in which Christ rouchsafes to be "the Begimning, the First-born of erery ereature;" in that sense in which it is said to Him, "Throu art My Son, this day have I begotten Theey." God never said so to any of the Angels, but He said it to Christ, when IIe "glorified Him to become an High-priest;" anointing the human nature that was in Christ with the Holy Glost, without stint or measure $^{z}$. That was at the moment of His Incarnation, for from that moment it pleased the Father that in Him should all fulness dwell - "all the fulness of the Godhead bodily." To that, and not to anything added by the Holy Ghost which had just descended upon Him, the word spoken from hearen at IIis baptism evidently refers: "Thou art My belored Son, in Thee I an well pleascd."

So also, I venture to think, does the quotation of S. Paul in Acts xiii. 33; although our translation wonld seem rather to connect it with the resurrection: "We declare unto you glad tidings, how that the promise made unto the fathers, God hath fulfilled the same unto us their children, in that

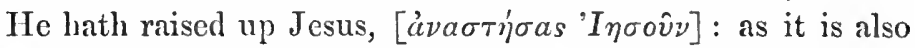
written in the second Psalm, "Thou art My Son; this day have I begotten Thee." " That this, not " raised up again," is here the more natural rendering of the word à $\nu a \sigma \eta^{\prime} \sigma a s$, may nppear from the texts eited below ${ }^{\text {a }}$. The leading idea seems to be that of "raising up a seed unto David to sit on his throne," and also (as in the text last eited below), to be a Priest as well as a King. And this will account for the repetition of the word with express reference to the resurrection in the following verse: "As concerning that IIe raised IIim from the dead, now no more to return to corruption, IIe saith on this wise, 'I will give yon the sure mercies of David.'"

That is the decree, the law, which the Father in the second Psalm declares, and the Son in the fortieth Psalm accepts "in the midst of His heart." Henceforth for ever the Son

8 Heb. v. 5 .

z S. John iii. 31 .

" Deut. xviii. 15;2 Sam. vii. 12 ;
Jer. xxiii. 5 ; Ezek. xxxiv. 23 ; Acts ii. 30 ; S. Matth. xxii. 24 ; llom. xv. 12, from Isaial xi. 10 ; IIeb. vii. 11. 
is made perfect Man, and as Man is to be adored with special Crsp. II. adoration by all the Angels of heaven.

$\S 4$. Observe again, aecording to this interpretation, the deep significance of that which is written by two Evangelists out of three in thicir report of our Lord's temptation. In S. Mattliew we read, "The devil leaveth Itim, and behold Angels came and ministered unto Him." But in S. Mark, from the condensation of the narrative, the lesson of adoration is brought out in a still more striking manner: "There came a Voice from Hearen, saying, Thou art $M y$ beloved Son, in whom I am well pleased. And immediately the Spirit driveth Him into the wilderness. And He was there in the wilderness forty days, tempted of Satan; and was with the wild beasts; and the Angels ministered unto Him "."

There is a mysterious correspondence, if I mistake not, between the order of these events and of those which happened on Christmas night. First, in both eases alike, Angels and men are called upon to take notice that the human presence of our Lord is the presence of the Only-begotten Son: with this difference, howerer, that at Bethlehem it was the actual Incarnation of the Word, His taking to Himself a natural body; by the river Jordan, it was His taking to Himself His mystical body, typified in His baptism, to which the Voice from the excellent glory referred. So we are instructed by one of the earliest fathers, S. Clement of Alexandria: "Unto the Lord at His Baptism sounded out from hearen a Voice, the Witness to the Beloved, "Thou art My Son, this day have I begotten Thee.'.... Whether these people will or no, must they not confess that the perfect Word, Offspring of the perfect Father, was perfectly regenerated by way of economy and prefiguration?... Now this same happens also to us, of whom our Lord became the representation. In baptism we are illuminated, in illumination adopted, in adoption perfected, in perfection immortalized. His word is, 'I said, ye are gods, and children of the Highest, all of you "." Angelical service follows in both, but in neither immediately. The hymn of congratulation at our Lord's birth, and the lowly ministry and homage after the

$$
\text { b S. Mark i. 11-13. }
$$

c Pieding. i. $25,26$. 
Cнap. II. proelamation at His baptism, (the former of which we know was accompanicd with adoration; and how can we doubt it concerning the other?) were each of them reserved, as it were, until His mysterious humiliation had been announced by additional circumstances. The multitude of the hearenly host did not sing Gloria in Excelsis until they had heard of the swaddling bands and the manger; the Angels did not come and minister unto Him who was declared the onlybegotten and beloved Son until He luad been cast out into the wilderness, had abode there forty days fasting, with no companions but the wild beasts, and (most mysterious and fearful self-abasement,) Satan tempting IIim. Then, not before, they were allowed to shew themselves at hand with their adoring homage,--homage paid as to Him whom they knew to be their Lord and their God, and aecepted by Him just after IIe had re-affirmed the rule, binding alike on angel and man, "Thou shalt worship the Iord thy God, and Him only shalt thou serve."

$\$ 5$. The same words were once again uttered by the same voice at our Lord's transfiguration: an earnest, no doubt, of His glory after His resurrection; but as they were not then aceompanied by any special humiliation, so neither was there any response of angclic praise and worship.

$\S 6$. But the next oceasion on which we do read of such ministration being aceepted by our Lord after the flesh, is when He was in the lowest and saddest of His agony: "His sweat was as it were great drops of blood falling down to the ground.-And there appeared an Angel unto Him from heaven, strengthening Him "." S. Luke, who singly relates this, had omitted the homage of the Angels in his account of the temptation, but had added, that the devil's then depart. ing from our Lord was but "for a season;" i. e. until the moment came which in the same Gospel is deseribed as the "hour" of Christ's enemies, "and the power of darkness." As though the good and bad spirits stood watching in their scveral ways for each new step in the process whereby He was " cmptying Himself of His glory ;" the one to indulge in their despairing fierceness, the other to pour themselves out in

$$
\text { a S. Luke xxii. } 41-4.4 \text {. }
$$


adoring love and duty. Thus both the one and the other Спар. II. sort became witnesses-the one willing, the other unwillingof His condescension, and of the victory thereby achieved; as the same Father again writes: "The Lord after His baptism is tossed as with a tempest for a type of us, and cometh first to be with wild beasts in the wilderness; then having overcome these and their prince, $\mathrm{He}$, as now a true King, is ministered unto by Angels. For He who in the flesh overcame Angels, good reason is it that Angels should now be His servants ${ }^{e}$."

There were Angels attending, too, on Christ's resurrection, but employed chiefly, as far as we are told, in guarding His tomb and grave-clothes, and other tokens of humiliation, and by them declaring His glory to those who came seeking Him.

$\S 7$. Thus from the moment of His Incarnation, while yet in this world under the veil of His flesh, as well as afterwards, now and unto the end of the world, while He is being "justified in the Spirit?",-shewn all holy and righteous by the dispensation of the Holy Ghost,--Jesus Christ was and is "seen of Angels;" or rather, as holy writers take it, "hath appeared unto Angels." For, "that is said to appear which hath it in its own power to be seen or not to be seen, and is not under the power of the person seeing. Thus we say not, 'The stone appears to me,' but 'I see the stone.' If, therefore, an Angel had it in his own nature or power to see the Word, it would not be said that the Word 'appeared' unto him, but rather that he himself saw the Word when he would. And therefore the Apostle saith, 'He appeared unto Angels,' because in their own nature they saw Him not. And true it is that from the beginning $\mathrm{He}$ appeared unto the Angels, when upon their turning towards Him He made them partakcrs of a divine nature; but when He was made flesh, many mysteries became known to the Angels which they had not known beforeg." These are the things which they stoop down from heaven "to look into,"-the sufferings of their Lord and ours, and the glories that follow : the sufferings

- S. Clem. Alex. Frangm., series i. § 85.

' 1 Tim. iii. 16.

Aquin. in 1 Ep. ad Tim. c. iii. 16. 
Crap. II. first, and then the glories; in that order "the manifold wisdom of God" is "made known by the Church to the principalities and powers in heavenly places ;" and whatever may be said of us fallen creatures, with them, we are sure, to know is to worship.

$\S 8$. Just as, on the other side, the evil Spirits, "the princes of this world"," came to know by degrees the "wisdom" which the gospel "speaks among them that are perfect;" a kind of "wisdom not of this world," but the "wisdom of God in a mystery ;" a wisdom which they knew not at first, for "had they known it, they would not have crucified the Lord of Glory ;" and as they knew more of it, they hated and scorned it more and more, as it is written, "The devil is come down unto you, having great wrath, beeause he knoweth that he hath but a short time." So from the beginning the Church taught, "There were three mysteries unknown to the prince of this world-the virginity of Mary, her lying-in at Bethlehem, and the true account of onr Lord's death; three mysteries most worthy to be proclaimed aloud, yet wronght in the silence of God ;" and the spite and malice of the devil was as discernible in regard of each of these mysteries, when he came to know them, as was the joy and salutation of the Angels; Herod, and the Pharisees, and Judas, being his instruments.

$\S 9$. That which, aecording to the same authority, takes place in the spiritual world among the good and bad Angels invisibly attending on every Holy Communion, is but another step in the same process. From the beginning it has been understood that the blessed Angels are ever at hand attending on the Christian altar, taking part in our hymns and thanksgivings, and wafting upward in a mysterious way all our dutiful prayers and offerings. S. Paul ${ }^{k}$ makes this wellknown fact a principle on which Christians ought to regulate all their demeanour, even their dress, in doing God service. "A woman ought to have power," i. e. some mark of her being under power and authority, "on her head, because of the Angels :" that everything may be done decently, and in order, in the presence of those glorious beings. And on the
h 1 Cor. ii. 6-8.
'S. Iguatius ad Ephes, c. 19.
k 1 Cor. xi. 10. 
other hand, Satan was waiting at the very first Eucharist of CHAP. II. all to enter into Judas Iscariot; and we know what great and peculiar danger there is of his entering in and re-possessing unworthy communicants.

Why are the Angels so especially present,-why is Satan so to be feared as near at hand,-in Holy Communion, more than in other Chureh ceremonies? Surely because the Gift is greater and nearer, and more distinctly applied to each one, and that with more unreserved condeseension on the part of the Giver, than on any other occasion in the Christian life. Surely because it is the Word made Flesh, personally present and revealed in the truth of His liuman nature, and offering thereby to make His own partakers of His divine nature also: and "wheresoever the Carcase," the holy slain Body is, "thither will the eagles be gathered together ;" the good, and saintly, and angelical Spirits to feed on it,-the Judases and enemies of Christ to mangle and to scorn it.

$\S 10$. All this is no more than Holy Scripture, as interpreted by the ancient Church, plainly teaches; and all this plainly implies a Real objective Presence of the Body and Blood of Christ, and that to be both eaten and worshipped, in Holy Communion. It implies such an union of condescension and power for the deification (so termed by the Fathers) of each one of us ${ }^{\text {b }}$, as the very Incarnation and Cross exhibited for the salvation and redemption of all mankind. Therefore, as our Lord newly incarnate, and nailed to His Cross, was to be specially adored by men and Angels, so also in this Sacrament.

$\S 11$. Other scriptural facts and associations tending to the same conclusion are, First, The reverence ordained to be paid, and always paid from the beginuing, to the Name of Jesus above all other names; to the sign of the Cross above all other signs; to the Gospels above other portions of Holy Scripture; and to Nazareth, Bethlehem, Calvary, above all other places.

Secondly, The peculiar significancy and use of the term Son of Man. 
Chap. II. Thirdly, The ways in which believers, while He was yet on earth, found themselves gradually and instinctively drawn to worship Him present in the flesh, and the manner in whieh He received that worship.

Fourthly, and above all, The account constantly given of the rationale of the Holy Eucharist itself, both as a sacrifice, and as a sacrificial feast.

$\S 12$. As the Body of Jesus during His earthly sojourn was marked out to be honoured by the holy Angels, so afterwards was the Name of Jesus also; and, as we may reverently belicve, for a like cause. The Body was to be especially glorified, as being the inferior part of Christ's inferior nature; the very footstool, as the Psalmist speaks, of His feet ${ }^{m}$; the "heel" of the Seed of the Woman, which was to be "bruised." In like manner, because Jesus is (humanly speaking) the name given to Him by a poor man as to a poor woman's child, - the name by which He was ordinarily known when supposed to be a mere man among men ;-because people called Him by that name while He went up and down as a carpenter's son, and Himself a carpenter, in the despised village of Nazareth;-because it was a name associated in the minds of all His acquaintance, during the first thirty years of His life, with the tasks and cares, and the very tools, of that ordinary trade; with recollections, indeed, of a most blameless and devout demeanour, but not as yet with anything transeendent, supernatural, or divine:-because it was the name which, being connected with Nazareth, (out of which town, it was taken for granted, no good thing could come,) proved afterwards through His whole ministry a most effectual stumbling-block to those who were unwilling to believe: beeause it was the name whereby $\mathrm{He}$ was deseribed as a Nazarene, the name which His enemies in moekery wrote upon His cross, as contrasting most signally with His high and sacred claims: because it was the name whereby $\mathrm{He}$ should be named in seorn among all generations of the unbelieving,-(whether worldly-minded Romans, who could not endure to be told "that there is another King, one Jcsus;" or bigoted Jews, exasperated by the notion that "this Jesus

m Ps. xcix. 5. 
of Nazareth shall destroy this place, and change the customs CHAP. II. which Moses delivered," and convinced therefore, with Saul, that they ought to do the most they could contrary to His name; or apostate Mahometans and heretics, in the East or in the West, delighting to call Him by that one of all His titles which they take to be merely of earth:) -in one word, because it is the name most expressive of His humiliation, therefore His thoughtful servants would instinctively select it in preference to all His other names for especial honour and reverence.

\$13. And so we see they did, prompted not by their feelings only, but by the special inspiration of God's Holy Spirit, whose will it was that in this way the dignity of Christ the Son of God, and His most true incarnation, might never want a witness. The Angels called Him by that name to His honour, remembering, no doubt, how they had brought it from heaven, "Be not affrighted; ye seek Jesus of Nazareth, which was crucified n;" and the evil Spirits in their tormenting dread of Him,- "What have we to do with Thee, Jesus, Thou Son of God?" "What have I to do with Thee, Thou Jesus of Nazareth ${ }^{\circ}$ ?" "What have I to do with Thee, Jesus, Thou Son of the most high Godp?" By that name, in preference to all others, the disciples proclaimed Him after His death $q$, and the Apostles after His ascension ${ }^{r}$. In that name they wrought their miracles ${ }^{8}$ : "In the Name of Jesus Christ of Nazareth rise up and walk ;" "Wneas, Jesus Christ maketh thee whole;" "I command thee in the name of Jesus Christ to come out of her." By that name the forgers of lies pretended to cast out evil spirits: "I adjure thee," they eried, "by Jesus, whom Paul preachetht." To the Name of Jesus were annexed all saving as well as healing powers; "By the Name of Jesus Christ of Nazarcth, whom ye crucified, whom God raised from the dead, even by Him doth this man stand here before you whole: neither is there salvation in any other; for there is none other name under heaven given among men, whereby we must be saved "."

n S. Mark xvi. 6.

o S. Mark i. 24.

p. S. Mark v. 7.

q Luke xxiv. 19. r Aets ii. 22.

8 Acts iii. 6 : ix. 34; xvi. 18.

'Acts xix. 13.

"Acts iv. 11, 12. 
Crap. II. Therefore to the Name of Jesus, rather than to any other, are to be referred the many promises made by God Almighty concerning His Name; whether things are said to be done $\tau \hat{\omega}$ ò $\sigma^{\prime} \mu a \tau \iota$, "by the use and instrumentality of it," as in S. Matt. vii. 22, "Lord, Lord, have we not prophesied in Thy Name? and in Thy Name have cast out devils? and

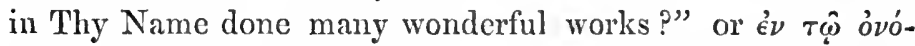
$\mu a \tau \iota$, implying that it is $\mathrm{He}$, not the visible agent, who docth the work, or obtaineth the blessing, as in S. Mark xvi. 17, "In My Name they shall cast out devils;" and S. Luke x. 17, "Lord, even the very devils are subject unto us through Thy Name;" and especially in the gracious promises near the end of S. John's Gospel, "Whatsoever ye shall ask

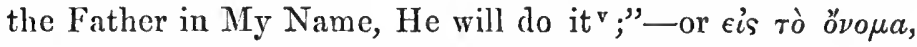
when in a mystery men are made or accounted partakers of the name, or of Him who is named, as in S. Matt. xviii. 20, "Where two or three are gathered together in My Name;"

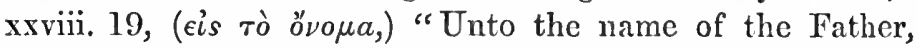
of the Son, and of the Holy Ghost;" and S. Jolnn i. 12, "But as many as received Him, to them gave He power to become the sons of God, even to them that believe on His Name;" which three texts declare respectively the virtue of the communion of saints, of baptism, and of faith, for the

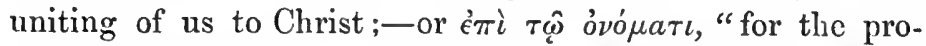
nouncing or profession of it;" as in S. Matt. xviii. 5, "Whosoever shall receive one such little one in $\mathrm{My} \mathrm{Name}$, receiveth Me;" and xxiv. 5, "Many shall come in My Name, saying, I am Christ;" and S. Luke xxiv. 47, "Remission of sins should be preached in His Name;" and Acts ii. 38, "Be

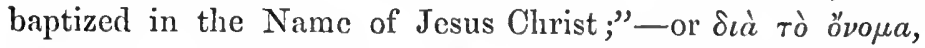
"beeause of the Name" ontwardly called on them, and made a ground of persecution, as in S. Matt. xxiv. 9, "Ye shall be hated of all men for My Name's sake;" and in S. John xv. 21, "All these things will they do unto you for My Name's sake."

$\S 14$. The Apostle, gathering together in one all these and the like promises, and the manifold daily fulfilments of

$\checkmark$ In one instance the same form of speech seems to indicate the distinc- tion of persons in the Godhead itsclf; S. John xiv. 26. 
them to which he was witness, did by the Holy Ghost enact Crap. II. and pronounce this canon, for the inward and outward worship of all God's reasonable and understanding creatures, not only in time, but in eternity, That "at the Name of Jesus every knee should bow ${ }^{x}$." Why at the Name of Jesus, rather than at that of Christ, or Immanuel, or Saviour, or any other of His good and great names? Why should Jesus be alone specified, as the Name which is above every name? Surely, if the Scripture did not expressly inform us, yet, from its indirect notices, such as have now been exemplified, a sufficiently probable answer might have been given to this question; but now we are not left in the smallest doubt. It was because, "being in the form of God," He " thought it not robbery to be equal with God: but made Himself of no reputation, and took upon Him the form of a servant, and was made in the likeness of men : and being found in fashion as a man, $\mathrm{He}$ humbled Himself, and became obedient unto death, even the death of the cross. Wherefore God also hath highly exalted Him, and given Him a Name which is above every name: that at the Name of Jesus every knee should bow, of things in heaven, and things in earth, and things under the earth; and that every tongue should confess that Jesus Christ is Lord, to the glory of God the Father." As if he should say, Jesus is His title of humiliation; therefore by that title $\mathrm{He}$ is evermore to receive especial homage.

$\S 15$. From Angels, both good and bad, He does receive it, as we have seen. In their several ways they bow, and ever will bow, their knees to the Name of Jesus. And the Holy Church from the beginning has venerated this Name above the rest, in affectionate reverence encouraging her children to refer to it on all occasions, in preference to any other of our Lord's names; as the very sayings of her enemies sufficiently prove, who cannot contain themselves for seorn at the cold, and strained, and forced allusions to that Name (so appearing to them) which the writers of the first ages are continually finding or inventing, both in Holy Scripture and in the course of nature and of Providence. $A$ single instance will sufficiently explain what is meant. S. Clement 
Crap. II. of Alexandria, in the course of an essay in which he traces out the mystical tenor of each of the ten commandments, as indicated by the number which marks its place, says of the collective meaning of them ally, "The Decalogue taken altogether doth, by the letter I. (=10) signify the blessed Name, setting before us Jesus, Who is the Word."

If you ask why this Name is set forth in preference to any other of His names, S. Augustine will answer for the rest - "Jesus has one meaning, Christ another: Jesus Christ our Saviour being one only; Jesus, nevertheless, is His proper Name. As Moses, Elijah, Abraham, were so called by their proper names, so our Lord, for His proper Name, hath the Name Jesus; whereas Christ is His sacramental Namez;" or, as $\mathrm{S}$. Augustine goes on to explain, His name of office, "as if you should call a man prophet or priest." That is why the Church has always distinguished the Name of Jesus above all other names,--because it is His very own Name; the Bride delights in it, because it is the very own Name of Him whom her soul loveth; His own Name, which He assumed as the token of His taking her to Himself for ever, and of the infinite, inconceivable condescension of His being made man in order to that union.

Therefore, as a distinguished mediæval commentator witnesses, "There is a common and laudable custom of the Church, whereby the Name Jesus is even more honoured than the Name Gop. For which cause, when the Name of Jesus is heard, the faithful people either bow the head or bend the knees; which they do not on hearing the Name of GoD ${ }^{\mathrm{a}}$."

S. Bernard gives a testimony such as one might expect from the author of the "Jesu, dulcis Memoria." Preaching on Canticles i. 3, Thy Name is oil poured out, he saysb, "I shew you a Name which is fitly compared to oil; how fitly, I will explain. Many titles of the Bridegroom you read here and there in every page of God's Book, but in two I will embrace them all for you. You will not, I think, find one which

y Strom. vi. 145. $\S 6$.

a Abulensis, in Corn. à Lapide on Philipp. ii. 10.

b. Serm. xv. $\S 1,3,4$. 
sounds not either of the grace of Mercy, or the power of Cris. II. Majesty. . These two things I have heard,-that power belongeth unto God, and that Thou, Lord, art Menciful. E. g. 'The Lord our righteousness' is a name of power; 'Emmanuel,' of mercy. Now the name of majesty and power is in a certain way poured over into that which is of mercy and grace; and the latter is poured out abundantly by Jesus Christ our Saviour... "Run, ye nations : salvation is at hand, the Name is poured out, which whosoever will eall on shall be saved." . "I recognise the Name of which I have read in Isaiah, He will call His own servants by another name, wherein whosoever is blessed upon the earth, shall be blessed in the Lord. O blessed Name! $\mathrm{O}$ oil poured out in all directions! Where will it stop? From heaven it runneth out upon Judæa, and thence over all the earth; and from the whole world the Church crieth out, Thy Name is oil poured out,--poured out, indeed, so that not only hath it imbued heaven and earth, but hath sprinkled also the unseen world, so that at the Name of Jesus every knee should bow, of things in heaven, and in earth, and under the earth, and every tongue confess and say, Thy Name is oil poured out."

It would appear that there was no need of enforcing this reverence by synodical enactment until one hundred years after S. Bernard; but in the second Council of Lyons, 1274, the Church uttered this among other most impressive warnings: " 'Holiness becometh the house of the Lord ;' it is becoming that He whose abode hath been made in peace, should be worshipped in peace with dne veneration. Wherefore let men's entrance into churches be humble and devout. Let their demeanour therein be quiet, well-pleasing to God, composed in sight of men, such as not only to edify, but to soothe thoughtful observer's. When they come together in that place, the Name which is above every name, besides which there is none other under heaven given unto men, wherein believing they must be saved, i.e. the Name of Jusus Christ, who saved His people from their sins,-- that Name let them exalt by manifestation of especial reverence. And that which is written concerning all, that 'in the Name of Jesus 
Crap. II. every knee should bow', the same let each for his own part fulfil in himself, (espeeially while the sacred mysteries of the Eucharist are being celebrated,) by bowing the knees of his heart at every mention of that glorious Name, and in witness thereof at least inclining his headc."

$\S 16$. Neither has the reformed Chureh of England ever had any scruple in continuing so dutiful a ceremony; only it appears by the 52nd Injunction of Queen Elizabeth, 1559, that there was need to enforce it, not as a new thing, but as an ancient custom in more or less danger of disparagement. "It is to be necessarily received, . . . that whensoever the Name of Jesus shall be in any lesson, sermon, or otherwise in the Church pronounced, due reverence be made of all persons both young and old, with lowness of courtesy, and uncovering of heads of the men kind, as thereunto doth necessarily belong, and heretofore hath been accustomed d".

In what quarter, and from what spirit, the necessity for this injunction arose, we may gather from the following passage of Cartwright's first Admonition": "When Jesus is named, then off goeth the cap, and down goeth the knee, with such a scraping on the ground, that they cannot hear a good while after, so that the word is hindered; but when other names of God are mentioned, they make no curtesy at all; as though the names of God were not equal, or as though all reverence onght to be given to the syllables."

What Hooker, on the part of the Church, replies to this, will be cited presently. Whitgift, affirming also the primitive origin of the ceremony, adds, in substanee, the same account of it:- "One reason that moved Christians in the beginning the rather to bow at the Name of Jesus than at any other name of God, was because this name was most hated and most contemned of the wicked Jews and other persecutors of such as professed the Name of Jesusf."

The royal injunction, as everyone knows, was confirmed a few years afterwards by synodical authority:- "When in time of divine service the Lord Jesus shall be mentioned,

c Hard. vii. 716 .

d Cardwell, Documentary Aumals, i. 198 . c Abp. Whitgift, Defence, \&c., 749.

Illooker, Ecel. Pol., V. xxx. 3, and note. 
due and lowly reverence shall be done by all persons present, $\underline{\text { Crar. II. }}$ as it hath been accustomed, testifying by these outward ceremonies and gestures, their inward humility, Christian resolution, and due acknowledgment that the Lord Jesus Christ, the true eternal Son of God, is the only Saviour of the world, in whom alone all the mercies, graces, and promises of God to mankind for this life, and the life to comc, are fully and wholly comprised?." And this regulation seems generally to have bcen acquiesced in, so far, at least, as that the Presbyterian divines in the Savoy Conference make no mention of bowing at the holy Name as one of the points which then disturbed men's consciences in the Prayer-book.

$\S 17$. Now all the reasons alleged from the beginning, and accepted by the universal Church and our own, for the honouring the Name of Jesus above all other names, hold with as great or greater force for special adoration of our Lord in the holy Eucharist, and make it still more imperative upon the prohibitors to produce some irresistible authority from Holy Scripture, or express Church law, if they would bring their prohibition home to a Christian man's conscience. Was Jesus the Name, among all His names, most expressive of His deep humiliation? So are the sacramental elements among all the mcans of grace, both as being in themselves so cheap and ordinary, and as representing especially His Death and Passion. Was Jesus our Lord's proper Name, brought from heaven, with a command that by It above other names we should make mention of Him? So was the holy Eucharist divinely ordained, that by it above all other rites we should make memorial of Him. Is Jesus His Name as a Man-one of ourselves? So is the holy Eucharist that by which He, the Wisdom of the Father, delightetlı to be among the sons of men ${ }^{\mathrm{h}}$. Is the Name of Jesus cspecially connected everywhcre with the hcaling, saving works of the Son of God, and expressly made adorable both by men and angels? Yet no promise associated with it can surpass what $\mathrm{He}$, who is Truth, has annexed for ever to the cating His Flesh and drinking His Blood. Has the reverence duc to this Name been cver cherished in the Church, as one great safeguard of 
Crip. II. the faith of His true Incarnation? So we know that against ancient heretics one topic for effectually asserting that same faitl in its integrity was the analogy between it and the doctrine of the Real Presence in the Eucharist, testified by our adoration.

It should seem, then, that whatever can be alleged for peculiar devotion to the holy Name, the same, and mueh more, can be alleged for peculiar devotion to the holy Thing received in the Sacrament; with this single exception, that we have no distinct form of words commanding us to adore in Holy Communion, as we have commanding us to bow at the Name of Jesus. But we have (as I hope presently to shew) declarations of our Lord fully equivalent to any such form of words. In the meantime, the simple fact that adoration is commanded at the mention of Christ's human Name might well warrant the Church in claiming it for the Real Presence of His holy Humanity.

$\S 18$. The same principle is recognised in the rubric which enjoins standing up while the Gospel is read; not, of course, as though it were more truly and entirely God's Word than the Epistle and other Scriptures are, but because it is that portion of God's Word in which He most abases Himself, hiding His Divinity and Majesty beneath that humble and lowly veil. So universal was this custom, that Sozomen, writing in the middle of the fifth century, knew but of onc exception to it, and that was in the Church of Alexandria, where the bishop continued sitting even at that timei. The Apostolical Constitutions ${ }^{\mathrm{k}}$, which, in sueh matters, may probably be taken as representing the general mind of the Church, direct as follows:- "When the Grospels are in reading, let all the priests and deacons, and all the people, stand up in great quictncss; for it is written, 'Be still, and hearken, O Isracl.' And again, 'But do thou stand here and listen." S. Chrysostom on the begimning of St. Matthew says, "Let us not therefore with noise and tumult enter in, but with the silenec due to mysteries; for if in a theatre, when a great silence hath been made, then the letters of the king are read, much more in this city must all be com.

$$
\text { iii.57. h ii. } 57 . \quad \text { ' Dent. 5. } 37 .
$$


posed, and stand with soul and ear erect. For it is not the Crap. II. letters of any earthly master, but of the Lord of angels, which are presently to be read."

The rationale of this, as of bowing at the Name, is expressed by Hooker in words which it would be wrong to omit, beeause they contain in them the prineiple of all that has been now alleged:- "It sheweth a reverend regard to the Son of God above other messengers, although speaking as from God also. And against Infidels, Jews, Ariaus, who derogate from the honour of Jesus Christ, such ceremonies are most profitable." As if he should say, "Behold God Himself coming close to us, and humbling Himself to do so: so much the more ought we to adore Him."

$\S 19$. By the same rule that the Name of Jesus is to be honoured above all other names, the sign of the Cross has been set apart from the beginning to be honoured above all other signs. I say, "from the beginning," for such undoubtedly is the case: it is not here as in some other Church usages: the further we go back in Christian antiquity, the more distinctly and unequivocally does this devotion appear. If we look to the employment of it in baptism, and in almost every other holy ceremony, as well as in the practice of ordinary life, we have the well-known witness of Tertullian ${ }^{\mathrm{m}}$. If to the instinctive use made of it in emergencies and dangers, spiritual or temporal, we have the allusion of S. Cyprian ${ }^{\mathrm{n}}$, the statement of Origen ${ }^{\circ}$, and the earnest exhortation of S. Chrysostomp. - If to the practical and mystical

m De Corona Mil. e. 4. ap. Ilooker, V. lxv. 2.

n ii. 125. "Muniatur frons, ut signum Dei incolume servetur."

- Fragm. from Origen on Ezekiel ix. 4 (after mentioning two other persons, with their interpretations) :-“ $A$ third, professing to have believed in Jesus, said that in the aneient alpliabet, Thau resembles the sign of the cross, and that the prophecy relates to the sign made among Christians on the foreheal, which all believers employ at the commencement of any transac. tion whatever, but especially of prayers and holy readings." It is the Samaritan Tluu-so the editor of S. Jerome adds-which Origen refers to. Ap. Oper. Hieron. v. 95; Origen, ed. Bened. iii. 424.

p 21 Hom. de Statuis, t. vi. 611; "When thou art on the point of stepping over the threshold of thy door, utter this word first, 'I renounce thee, Satan, and thy pomp, and thy service; and I enrol myself under Thee, O Christ.' And do thou never go ont without this word. This shall be to thee a staff, a shield, an impregnable tower. And with this word form thon also the eross upon thy foreheal : for so, not ouly no man meeting thee, but not even the devil himselt shall be able to burt thee at all." 
Crap. II. way of detecting allusions to it in nature, we have S. Justin Martyr referring the very heathen to itq. If, lastly, we look to their expositions of Holy Scripture, we find among those early writers a consent all but universal and unhesitating; the Law, the Prophets, the Psalms, from beginning to end, disclosing to their Christian instinct anticipations of the blessed Cross : and, chiefest of all, we find them with a wonderful accord interpreting our Lord's own solemn prediction, "Then shall appear the sign of the Son of Man in heaven ${ }^{r}$," of some mysterious appearance of the sign of the Cross. And it cannot be denied that our Lord's own words give countenanee to the interpretation, in that from a very early period of His ministry, from the very first mission of the Apostles, He spoke to them of the Cross as of that which must be taken up in order to follow Him; thus making it His badge, apparently, long before they could know His meaning ${ }^{8}$. And it is plain that by the time S. Paul wrote his Epistles to the Corinthians and Galatians, the "preaching of the Cross" had come to be understood as equivalent to the preaching of Christianity; the whole Gospel being denominated from that outward and visible thing, which $\mathrm{He}$ made the providential instrument of the most awful and mysterious fact revealed in it. In a word, the exaltation of the Cross above all other Christian signs is the most pregnant, or rather the crowning, instance of the rule, "He that humbleth himself shall be exalted," and would lead us to anticipate some signal honour as likely to be accounted due to the holy Eucharist, associated as that Sacrament inseparably is with what took place on the

q 1 Apol. 55.

r S. Matt. xxiv. 30 . On which verse Origen (iii. 866) says: "The sign of the Son of Man will then appear, whereby have been made lieavenly, the things which were in heaven, and which were in earth; i.e. the wonder wrought by the Son hanging on the tree: and in heaven more especially His sign shall be bright." And S.Cyril of Jerusalem (Catech. xiii, 45) : "This sign shall appear again with Jesus from heaven. For the King's trophy shall lead the way; that secing Him whom they piereed, and by the Cross recognising the dishonoured One, the Jews may repent and mourn, and we may exult." And S. Chrysostom, Hom. in Matt. liv.: "Be not thon ashamed of so great a good, lest Clurist be ashamed of thee, when $\mathrm{He}$ cometh with $\mathrm{His}$ glory, and the sign appeareth before Him more brilliant than the very smbeam. For inled the Cross is then coming, uttering a voice by the very sight of it," \&e. And Hom lxxxi.: "Then shall appear the sign, i. e. the Cross, being brighter than the sun; since it appears when the sun is darkened, and hiding itself."

s S. Matt. x. 38 ; ef. xvi. 22 ; S. Luke xviii. 34 . 
Cross, and with the further humiliation, that He who made Cндp. II. and filleth all things doth vouclisafe to veil Himself under symbols so cheap and ordinary, ("a little bread and wine,", as speaks a devout writer,) and thereby to submit His blessed Body to so many reproaches and indignities.

$\S 20$. The Name of Jesus being thus honoured above the rest of our Lord's Names, and the sign of the Cross above all other His Signs,- - the Vine, the Lamb, the Fish, the Branch, and the like; -no wonder that among the places made holy by His earthly abode or mighty works, those have ever been most venerated which saw most of His humiliation and sufferings; and before all the rest, Nazareth, Bethlehem, and Calvary. In the honour paramount to all others, which Christendom has ever paid to those three places, we perceive an instinctive acknowledgment of our Lord's true Incarnation and Atonement. Had $\mathrm{He}$ been but the chief of men, the places of His conception, birth, and death would have been indeed exceedingly interesting; but the interest would not have been comparable to what would have been felt in visiting Capernaum and the other great scenes of His ministry. The constant feeling of Christians on this subject has been a witness from age to age of their belief in Him, God made Man, and of their yearning to express that belief in all holy ceremonies,-religious pilgrimage being one. If, through the changed circumstances and habits of the Christian world, we are in a way preeluded from this or any other form of devotion, it is but natural that we should cling the more earnestly to those modes and forms which Providence still leaves within our reach; jealously guard them, and scrupulously make the most of them. If we cannot be pilgrims, we will at least, please God, be humble worshippers in the holy Eucharist.

$\S 21$. Why, again it may be asked, is the term "Son of Man" beyond all others His own chosen title, whereby He speaks of Himself, and whereby His beloved disciple", and first martyr ${ }^{v}$-no others-are permitted to speak of Him? Not, surely, for love's sake only, and to signify how that it is His
'De Imit. Clristi, IV. ii. 5.
"Rev. i. 13 ; xiv. 14.
$\checkmark$ Acts vii. 56. 
Crap. II. delight to be with the sons of men; but for truth's sake, and for doctrine's sake;-or rather, in this question, love, and truth, and doctrine are all one. From His first assuming of the title when He spake to Nathanael, within three or four days of the beginning of His ministry, until the last applieation of it in Holy Scripture, when S. John saw sitting on a cloud "one like unto the Son of Man,"-forty-two instances, or thereabouts, - we do not find one which is not emphatically marked as conveying this lesson, - that all our participation of God, or of any good thing, is by way of virtue flowing out from Christ's holy Humanity, which is therefore to be specially loved, and adored, and trusted in by us, with an infinite love, trust, and adoration: that saying of the wise man being eminently appropriate here; "When ye glorify the Lord, exalt Him as much as ye can; for even set will He far exceed: and when ye exalt Him, put forth all your strength, and be not weary; for ye can never go far enoughx."

To take a few signal instances:-As the Son of Man He re-opens the miraculous intercourse between heaven and earth, now in a manner suspended for many generations. Heaven is seen opened, and "the Angels of God ascending and descending upon the Son of Man." As the Son of Man He is in such sense one with God, His Person being truly divine, that $\mathrm{He}$ is at the same time in heaven and in earth, having come down from heaven. He "hath power on earth to forgive sins;" "authority" is given Him of the Father "to execute judgment ;" He is "Lord of the Sabbath ;" He will one day "confess" His own "before the Angels of God;" it is He who "soweth good seed" in the worldy.

But most remarkably is this title conneeted with His office at the last judgment. The Son of Man will be glorified, will sit on the throne of His glory, will come in the glory of His Father with His angels; His sign will appear before Him in heaven; we shall see Him eoming in a eloud with power and great glory. His martyrs even now see Him by faith at the right hand of God; His friends, in vision among the golden lamps, which are His Churches; and both

× Ecclus. xliii. 30 .

ix. 6 ; S. John v. 27 ; S. Matt. xii. 8 ;

s. John _. 52 ; iii. 13 ; S. Matt. S. Luke xii. 8; S. Matt. xiii. 37. 
friends and enemies will see Him ere long on the cloud, Снар. II. which is His throne, about to reap the harvest of the earth ${ }^{2}$.

All these wonders are His work, as He is Son of Man; and by the same title He claims to Himself all His marvellous and mysterious sufferings: He hath not where to lay His head; He cometh eating and drinking, to incur the Pharisees' reproach; He veileth His greatness, so that a word against Him may be forgiven; He is buried three days in the heart of the earth; He must suffer many things, and be set at nought, and will not endure that His disciples should disbelieve it; He must be lifted up, for He is not come to destroy men's lives, but to save them; not to be ministered unto, but to minister; He must be betrayed, and go as it is written of Him; betrayed by Judas,- - betrayed with a kiss ${ }^{\text {a }}$.

"I, the Son of Man","-such is the title which from the first He had taken to Himself in preference to all others; signifying thereby to thoughtful hearts, that $\mathrm{He}$ was the very seed of the woman, the second Adam promised to undo what the first had done. And each successive application of the title, whether in the way of power or of endurance, may be seen to bring ont more and more fully this His gracious remedial office.

We shall see presently how devotion to the title, Son of Man, is by His own word connected with devotion to His blessed Body. But to appreciate this duly, we must go back to the beginning of our Lord's ministry, and consider at large what the Gospels record, be it much or little, of things said or done by Him, in a way to teach or encourage this latter devotion.

\$22. Now as we have seen that to the angels our Lord's humiliation in the flesh was a mystcry, which they had to learn by degrees, so to His disciples and friends on earth was the exaltation of that flesh; and they were trained by their experience of the virtue which went out of it in the way of corporal and physical miracles, to believe in and

z S. John xii. 23 ; S. Matt. xix. 28, xvi. 27 , xxiv. 30 ; Acts vii. 56 ; Rev. i. 13 , xiv. 14 .

a. Matt. viii. 20 , xi. 19 , xii. 32 , ib. 40, xvii. 22, xx. 18; S. John xii. 35 ; S. Luke ix. 56 ; S. Matt. xx. 28 , xxvi. 24 , ib. 45 ; s. Luke xxii. 48.

b S. Matt. xvi. 13. 
Crap. II. adore its wonder-working presence, when it should be made known to them as the very food and medicine of their souls. The Forerunner himself declared that he did not at first know our Lord. His Person he probably knew, for in the flesh he was near akin to Him; he knew so much of Him before $\mathrm{He}$ came to be baptized, as to decline, if it might be, performing such an office for one so far his superior; but lie knew not as yet the fulness of the divine economy, for which Jesus came into the world; he knew not that this was the very Son of God, who was to baptize with the Holy Ghost, according to John's own announcing, and so, i. e. by a dispensation of sacraments, to fulfil all righteousness, in the justification and sanctification of His electc.

All this John came to know by the marvellous course of our Lord's baptism, and from henceforth he referred his disciples directly to our Lord; and our Lord, accepting their implicit faith, promised them, through Nathanael, immediate confirmation of it by miracles: and the very next day was the first miracle, in Cana of Galilee, Nathanael's home; a miracle best explained, surely, as a symbolical preaching of the new heaven and the new earth, to be brought into being by that participation of Christ whereof Wine was to be a principal instrument.

Then followed that course of miracles in Jerusalem, about the time of the first Passover, which brought Nicodemus to be instructed, and concerning which He signified to the Jews, that they were but the earnest of a greater miracle, whereby His Body should be proved to be a true Templea living Temple-the personal abode of the Word made Flesh and dwelling among us.

$\S 23$. For the three years afterwards during which " $\mathrm{He}$ went about doing good, and healing all that were oppressed of the devil," it will be found on examination that His ordinary miracles, by far the greater part of them, were wrought not without some visible touch of His Body. There seems an incongruity in measuring and counting such things, "the works of God, who maketh all ;" yet since He has condescended to set down for our learning a certain number of

c See this proved by S. Augustine, in Joh. tr. v. 
them, it cannot be wrong to take notice of that number; Снar. II. and so it is, that if you reckon up the miracles of healing especially recorded as wrought by Christ in the flesh, you will, I believe, find that two-thirds, twenty-two out of thirtythree, were wrought, as was said, by the Touch, immediate or virtual, of His Body.

$\S 24$. The exceptions are, first, Five instances in which $\mathrm{He}$ had to do with unclean spirits; for, whatever were the reason, it does seem that He never laid His hand upon demoniacs. The distinction is strongly marked in one of the first instances, towards the beginning of the Gospel: "In the Synagogue," at Capcrnaum, "there was a man which had a spirit of an unclean devil "," who did as it were challenge and defy the Holy One; him Jesus rebuked, "saying, Hold thy peace, and come out of him. And when the devil had thrown him in the midst, he came out of him, and hurt him not. And they were all amazed, and spake among themselves, saying, What a word is this! for with authority and power He commandeth the unclean spirits, and they come oute." Presently after, on leaving the synagogue, He went " into Peter's house, He saw his wife's mother laid, and sick of a fever. And He touched her liand, and the fever left her: and she arose, and ministered unto them ${ }^{\mathrm{f}}$." The evil spirit He cast out with a word; the sick woman He took by the hand and lifted her up.

These two miracles, occurring in the middle of the day, were followed the same evening by multitudes in each kind; in all of which, as we learn by comparison of the several accounts, the same difference was observable. S. Matthew says, "When the eren was come, they brought unto Him many that were possessed with devils: and $\mathrm{He}$ cast out the spirits with His word, and healed all that were sickg;" and S. Luke adds how these latter were healed: "He laid His hands on every one of them, and healed them ${ }^{h} . "$ As to the unclean spirits, he mentions them apart in the next verse; "and devils also came out of many, crying out, and saying, Thou art Christ the Son of Godi."

d S. Yuke iv. 33.

I Ibid. 16.
- Ibil. 35,36 .

b S. Iuke iv. 40 .

1) 2 is. Matt. viii. 1t, 15.

i Ibid. 41. 
Crap. II. Again, at the great manifestation of Himself which accompanied the ordination of the twelve, we arc told by another Evangelist nearly in the same words, "He had healcd many; insomuch that they pressed upon Him for to touch Him, as many as had plagues. And unclean spirits, when they saw Him, fell down before Him, and cried, saying, Thou art the Son of Godj."

The only case recorded of His touching a possessed person is that which occurred just after the Transfiguration. "When Jesus saw that the people came running together, He rebuked the foul spirit, saying unto him, Thou dumb and deaf spirit, I charge thee, come out of him, and enter no more into him. And the spirit cried, and rent him sore, and came out of him: and he was as one dead; insomuch that many said, He is dead. But Jesus took him by the hand, and lifted him up; and he arose ${ }^{k}$." This, however, it will be presently seen, is no exception, but critically confirms our allegation. The devil was cast out by His mere word; when He touched the sufferer's hand, and lifted him up, it was but to revive him from his exlıaustion,- - the dispossession being before complete.

We may reverently ask, why this distinction? and we seem to have an answer, if we may assume the course of our Lord's miracles generally to be symbolical of the greater invisible miracles which $\mathrm{He}$ was to work by His Spirit in His Church; i. e. of His holy sacramental system; according to His most true promise,- " Verily, verily, I say unto you, He that believeth on $\mathrm{Me}$, the works that I do shall he do also; and greater works than these shall he do; because I go unto My Father." On that hypothesis, the spiritual exorcism which must go before the spiritual touch of Christ,-so distracting and agonizing, sometimes, even in its outward and visible effects,-may well be represented by the spirit's crying out, tearing and rending the poor patient, at the very sight of his Deliverer, and much more at the command to "come out of the man;" and the purifying, strengthening, refreshing grace of the two great Sacraments, whereby we are made participators of Christ, answers to His loving and powerful
j S. Mark iii. 10, 11.
k. S. Mark ix. 25-27.
${ }^{1}$ S. John xiv. 12. 
Touch, taking him, as he lay, by the right hand, and lifting Cusp. II. him up.

\$25. Six other cases occur in which, for aught we see, our Lord might have touched the person, and it pleased Him to heal with a word only. In each of these we may observe, I think, unusual stress laid in the narrative on the Faith of the person receiving the cure, or of those by whom he was presented to our Lord. Two of them happened at Capernaum, to persons of rank. The nobleman, somewhat tardy in his belief, was however rewarded for it when it came, by our Lord healing his son at a distance; the Centurion, his townsman, in his good and ready confession at once of Christ's power and of his own unworthiness, shewed a faith marvellous even to Jesus Christ Himself. Of those who brought the man sick of the palsy we read, "Jesus seeing their faith," forgave and healed him-not without some trial of the sufferer's own faith also; for it was a great trial to so helpless a person to set about obeying the command, "Arise, take up thy bed and go unto thine house." The like may be said of what happened at the pool of Bethesda, and of the man bidden to stretch forth his withered hand; and, in a different way, of the ten lepers setting out to shew themselves to the priests. By these comparatively rare examples our Lord may have designed to symbolize the necessity of faith in all capable receivers of sacraments, and the sufficiency of it in certain cases without literally receiving; according to the principle, Gratia Dei non est alligata sacramentis.

$\S 26$. But however this may be, the general fact is obvious to the most cursory reader of the Gospel, that almost as soon as ever He came to be known by His miraculous cures, the touch of His blessed Body came also to be known as the ordinary visible mean whcreby He performed them. Beginning from Simon's house and the streets of Capernaum, "the fame of Him went out into all Syria," not only of His healing, but of His touching or laying on of hands in order to heal ${ }^{\mathrm{m}}$. Theneeforth we meet with such sayings as, "Come and lay Thine hand upon her, and she shall live;" the deaf and the 
Cнap. II. blind are brought to Him, with a request that He would lay His hands upon them; mighty works are said to be done by His IIands; He could do no mighty works at Nazareth, save that " He laid His hands upon a few sick folk;" - the turn of expression indicates how completely the idea of mighty works of healing was associated in the writer's mind with laying on of hands. Indeed, it could not well be otherwise, seeing that our Lord Himself, promising miraculous power to the first generation at least of those who should believe, had used the same form: "they shall lay hands on the sick, and they shall recover"." After a while it came into the heart of the humble person with the issue of blood to come and touch the hem of His garment; and, instead of a reproof for superstition, she received not only the virtue which went out of Him to heal her, but also His solemn approval, and a blessing on her faith. And this, too, spread abroad; so that a short time after, "wheresoever He entered, into villages, or cities, or country, they laid the sick in the streets, and besought Him that they might touch if it were but the border of IIis garment: and as many as touched Him were made whole ${ }^{\circ} . "$

It should seem, moreover, that an additional sanction to this popular notion is supplied by each of those rcmarkable cases in which our Lord was plcased to withdraw Himself, and deal in a peculiar way with certain sufferers; such as the deaf and dumb man in S. Mark vii. Being asked only to lay His hand on him, He takes him apart from the multitude, puts His fingers into his ears, spits, and touches his tongue; and again, at Bethsaida, a blind man is brought to Him with the same petition: "and when He had spit on his eyes, and put His hands upon him, He asked him if he saw ought. And he looked up, and said, I see men as trees, walking. After that He put His hands again upon his eyes, and made him look up: and he was restored, and saw every man clearly ${ }^{\text {." }}$ And then the well-knowu cure of the man born blind, in S. John ix., which also seems to have taken place in private: "He spat on the ground, and made clay of the spittle, and He anointed the eyes of the blind man with the clay, and said unto him, Go, wash in the pool of Siloam, (which is by
n S. Mark xvi. 18.
- Ib. vi. 56.
P Ib. viii. 23. 
interpretation, Sent). He went his way therefore, and washed, Crap. II. and came seeing." These may well remind us of the singular and exact discipline ever observed when the Church was free to use it; the cure of all inward evils being one and the same,-the Body and Blood of Christ,--but the time and mode of its application, and the degree of tender and charitable reserve employed, varying much with the specialities of the case.

$\S 27$. The minds of the disciples, and indeed of all within hearing of our Lord, being thus providentially trained to think much of His blessed Body as the instrument of all good to them; and also, as we have scen, to regard His title, Son of Man, as indicating rather than any other the relation in which $\mathrm{He}$ vouchsafed to stand to them; it could not but strike them deeply (such as were at all thoughtful among them), and dwell much upon their minds, when towards the beginning of the third year of His ministry (a time of many great revelations concerning Himself), $\mathrm{He}$ bound the two ideas together in the way recorded by S. John. He told them, first, that the Son of Man should give them meat; secondly, that this meat was only to be had by eating His flesh and drinking His blood; and, thirdly, that this was to be done in a heavenly, supernatural manner-a manner cognizable only by faith, since it would be consistent with their seeing "the Son of Man ascend up where He was beforeq." If the title, "Son of Man," as the Church has always believed, means the Second Adam, the root of life as Adam of death,coming in a true body to save men's bodies as well as their souls, - what were they to imagine of this eating unto life, but that it should be as real and true, as was that by which Adam ate unto death? a real and true cating of His real and true Body, which should constitute a great and indispensable portion of the marvellous system of divine mercies now in course of being revealed to them. It is plain they did so understand Him; why otherwise should they be offended? Had the eating and drinking becn commonly understood, as some writers think, to be a sort of parable, a figure to cxpress tho 
Crap. II. receiving our Lord's doctrine, there was nothing in that saying so hard, but they might very well have borne with it. But we see that at the time it was taken by all, both friends and enemies, as a great and real mystery, and that it proved just the same sort of trial to the Jews who drew back, to the Eleven who believed, though they could not understand, and to Judas, who remained with Christ in hypocrisy, as the Holy Communion has evermore bcen to rejectors and unworthy receivers on the one hand, and to faithful communicants on the other.

It must not be overlooked, that around these great sayings are gathered, as it were, a group of miraculous doings, every one suggesting more or less plainly the supernatural virtue of our Lord's body. First they came to Him and He healed their sicknesses; then-not without His taking them into His hands and breaking them-the loaves were multiplied and distributed; then in His true flesh, by the power of His true Godhead, He walked on the water; then He communicated virtue to His favoured Apostle to do the same; and when he was sinking and eried out, "Jesus stretched forth His hand and eaught him;" finally, "when they were gone over, they came into the land of Gennesaret: and when the men of that plaee had knowledge of Him, they sent out into all that country round about, and brought unto Him all that were diseased; and besought Him that they might only touch the hem of His garment: and as many as touched were made perfectly wholer."

$\S 28$. And what if the other miracle, happening so soon after, and recalling this by so many circumstances, were intended to represent the great doctrine and ordinance under another of its "aspects?" I mean the feeding of the four thousand with seven loaves and a few small fishes ${ }^{5}$. If the former miracle was typical of the Eucharist, as by the consent of Christendom (one may say) it most certainly was, it seems hard not to associate the later one also with that sacrament. And if, as ancient writers teach ${ }^{t}$, and as the

s S. Matt. xiv. 35,36 .

- S. Matt. xv. 32 ; s. Mark viii. 1.

\$. Aug. Serm. 227: "Si bene ac. cepistis, vos estis quod accepistis. Apostolus enim dicit, 'Unus panis, unum corpus, multi sumus.' Sic exposuit Sa- 
chief of the schoolmen undoubtedly taught, (grounding their CHAP. II. opinion mainly upon S. Paul's saying, "For we being many are one bread and one body: for we are all partakers of that one bread ;") the Church, or mystical body of Christ, may be regarded as present by the real presence of His heavenly and glorified Body, and so as constituting-in a secondary sense, and one infinitely below the glory and dignity of the other, yet in a very true sense-the res sacramenti, or thing signified in Holy Communion" ; then the circumstances of the miracle in question may seem to make it a sufficiently apt parable for the expression of that doctrine. The twelve lonves being a known symbol in the old dispensation for the twelve tribes, i.e. for the whole Jewish Church, and as such presented day by day in the temple; and seven being the number which from the beginning, in the figurative language of Scripture, had represented completeness ${ }^{x}$; the seven loaves, by no forced analogy, might be taken to represent the whole Christian Church, and the partaking of them after Christ's special blessing, to signify that union and incorporation of Christians one with another, which, depending on their union with Christ their Head, is perfected more and more by every sacramental participation of Him; aceording to His own prayer, offered in conjunetion with the very original Eucharist: "That they all may be one, as Thou, Father, art in $\mathrm{Me}$, and I in Thee, that they also may be one in Us.."

And since the Fish is an acknowledged emblem both of our Lord and of His members, and in the former miraele the two fishes are considered by S. Augustine ${ }^{z}$ to represent Christ in His two characters of King and Priest, it migltt not, perhaps, be straining the exposition of this latter miracle too far, were we to conjecture that the few small fishes which " $\mathrm{He}$ blessed and commanded to be also set before them," might

cramentum Mensa Dominica." Cf. Serm. 229, 272. "Si vos estis Corpus Christi et membra, mysteriun vestrum in mensa Dominica positum est : mysterium vestrum accipitis."

- Aqninas, Summ. Theol. p. iii. qu. 60. 3: "In Sacramento Altaris est duplex res significata, scilicet Corpus Christi vemun et mysticum;" qu. 80.
4: "Duplex est res hujus Sacramenti ... una quidem, qux est significata et contenta, scilicet ipse Christus; alia autem est significata et non contenta, scilicet Corpus Christi mysticum, quor est societas Sanctormm."

$x$ s. Aug. Serm. xcv. 2.

y S. Jolin xvii, 21.

z De diversis quast. lxi. 2, t. vii. 25. 
Cris. II. represent the holy martyr's and other eminent saints, few, and very small in comparison, but in some especial manner and degree having Christ imparted to them more than to the rest, and therefore especially called by the same title with Him; and the partaking of those fishes may answer to the Communion of Saints, as that of the loaves to our portion in the holy Catholic Church. The four thousand may be the multitudes coming in from the four winds of heavennorth, south, east, and west,-to sit down with Abraham, Isaac, and Jacob in the spiritual feast, the kingdom of heaven. If the old method of interpretation be at all allowed, this would seem no improbable account of the second miraculous feast, occurring so soon after the first, and tending in its degree to deepen the impression that the Body of Christ was to be, in some mysterious way, all in all to those who should be saved by Him.

$\S 29$. Very shortly after, but not until His Divine nature also had been more openly than ever declared to His disciples, by the benediction pronounced to $\mathrm{S}$. Peter on his confession, -nor yet until $\mathrm{He}$ had begun to predict to them in detail what $\mathrm{He}$ was to suffer,- $-\mathrm{He}$ took His three chosen into a high mountain apart, and shewed them that Body, in which He had so many ways invited them to trust, transfigured,His face shining as the sun, and His raiment white as the light;-thereby, as it may appear, giving them to understand something of the properties of His glorious Body; at the same time that, by the discourse in their hearing with Moses and Elias, He prepared them to see it in the lowest humiliation and suffering. And twice on the same occasion He taught them to believe that it was, and always would be, a real Body; and as such the instrument of all good to all believers, by touching, first, the three saints, (as Ezekiel and Daniel had been touched of old,) and so enabling them to endure the beatific vision; and presently afterwards by touching the young man out of whom the evil spirit had been cast, and restoring him to his father, and to the state of probation and hope.

Between the Transfiguration and the week of our Lord's Passion there is nothing on record to draw attention to the 
prerogatives of His blessed Body, if we except perhaps what CHAP II, took place at the Fcast of Tabernacles, in the last year of His preaching,-when, having asserted His Godhead, and seeing that the Jews were taking up stones to stone Him, Jesus made Himself invisible, "and went out of the temple, going through the midst of them, and so passed by ${ }^{a}$ " And "passing by," He healed the man blind from His birth; not without spitting, and making clay of the spittle, and anointing the eyes of the blind man with the clay; proceedings well calculated to impress those who knew of His Transfiguration, especially, with an increasing awe towards that Body which they saw so marvellously and peculiarly gifted, beyond the bodies of the sons of men; and with a wondering expectation what Almighty God might be on the point of working thereby.

$\S 30$. The Holy Week itself begins with the anointing at Bethany, commended by our Lord Himself to all ages as a signal instance of devotion to His blessed Body, and ever understood by the holy Church as a warrant for sparing no trouble nor expense in providing for that Service, which acknowledges the mysterious continuance of the same among us. She must not be troubled nor interfered with; "she hath done it for My burial ;"-it was as impossible for her to help doing it now, as it was for her, or one very like her, to abstain from the like loving worship, when she first came to $\mathrm{Me}$, loving much, and hoping, as far as she might dare hope, to have much forgiven;-as impossible as it will be within a few days for her not to wait on Me with spices and ointments, when I am to be laid in My grave;- " trouble her not," "she hath done what she could;" "she hath wrought a good work on Me"." And why was that work so significantly decreed to be spoken of throughout "the whole world," but that all might understand that they could not go too far in loving, honouring, adoring that Body which He had vouchsafed to takc into His divine Person, by which He was about to save the world, which was soon to endure such humiliation for our sake, as nothing could equal, save the glory to which it was afterwards to be visibly cxalted for our perfect salvation? 
Chap. II. Moreover, in close connection with this comes another thought, indescribably fearful, as it seems to me, if we carry it out:- what manner of man he was who suggested to his fellow-disciples to have indignation and count it "waste," as though too much were being made of Christ's real, and then visible, Body, and the poor, His mystical body, werc being robbed.

Others in their simplicity for a moment adopted the notion, but they presently received His correction; Judas, who had devised the scruple in hypocrisy, refusing to be corrected, (though never surely were such gracious warnings addressed to any one that we read of,) went out to commit the two most outrageous sins that could be committed against that blessed Body: first partaking of it with a heart and mind actually at the moment determined on betraying it, and so actually betraying it, as far as in him lay, to Satan, who forthwith entered into him; and afterwards, openly in the sight of man betraying it-betraying the Son of Manby a kiss;-the loving penitent's token of adoration was the hypocrite's token of insult and unearthly malice.

And then, as if to prove that the holy Flesh which endured all this, and was about to endure much more, was still, as ever, the Temple of the divine glory; first, by shewing Himself, and declaring, "I am He," He forced His assailants to recoil and fall to the ground, either on their faces in involuntary worship, or backwards as in despair. Presently afterwards He touched Malchus' ear, and healed him. The cure was wrought by His touch, as in so many instances before. And since the man had been hurt in laying rude liands upon His Body, the healing may be received as a merciful token, that even unworthy communicants are not shut out from His mercy, and the benefit of the mysteries which they have profaned, except they persist in unworthiness.

$\$ 31$. Then it was that our blessed Redeemer, withdrawing, as it were, His power into Himself, gave up His Body to the sacrifice, with the words, "This is your hour, and the power of darkness." His disciples understood Him to signify that nothing more could be done for Him, and they might as well forsake Him and fly; His enemies, both on earth and in hell, knew that they were left to do thcir worst with Him; 
and they did it unsparingly; and while His Body was, in CHap.II. fact, winning the decisive and eternal victory for which $\mathrm{He}$ came into the world, it seemed to the eyes of men, perhaps of all creatures, to be surrendered, for good and all, to suffering and insult. But the first thing seen, when the preternatural darkness was over, and the light of day was again permitted to shine upon the cross and those standing by it, was the blood and water, flowing out from our Saviour's side, as soon as ever He was certainly known to be dead.

There is no need here to explain at large the symbolical and sacramental meaning of that miracle,-a meaning witnessed by all antiquity, and adopted by the Church of England especially in her office of Holy Baptism, where she deelares that, "for the forgiveness of our sins, Christ shed out of His most precious side both Water and Blood." "His most precious side:" the very phrase instinctively indicates what all devout persons have felt towards that sacred Form, drawn to it the more by this parting insult from those who were bent upon making themselves every way "guilty of the Body and Blood of Christ our Saviour."

We may perhaps realize those feelings most effectually, by reverently imagining how they may have begun in the heart and mind of the beloved disciple, chosen by the Holy Ghost to testify the trimsaction to us, and of the blessed Virgin, and other holy women; the special alarm and horror which they must have felt as they watched the brutal soldiery breaking the legs of the two malefactors, and approaching their Lord's cross with the same intent; the comparative relief when they saw that all that was done was ignorantly and wantonly to pierce His unconscious side; the awful sense of Divine interference and of Divine consolation, when, knowing that He was already dead, they saw the stream gush out, not of blood only, but of water and blood. Probably, indeed, it was in this instance as is noted elsewhere in S. Johu's Gospel": "These things understood not His disciples at the first: but when Jesus was glorified, then remembered they that these things were written of Him, and that" His encmies "had done these things unto Him." Yet the very tone

$$
\text { c Chap. xii. } 16 .
$$


Cris. II. of the narrative implies that even at that moment of exceeding grief and dismay, the Evangelist's mind-as often happens when dearest friends are departing-was deeply impressed with the circumstance, and would naturally go on wondering what it could mean. "He that saw it bare record, and his record is true: and he knoweth that he saith true, that ye might believed." Perhaps it should be written " He knoweth," for the Greek words ( $\kappa \dot{\alpha} \kappa \epsilon i \nu o s$ oí $\epsilon \nu$ ) will bear that construction; as though the historian were saying with S.Paul, "Behold, before Grop, I lie not." But that it should be inserted with such an asseveration, calling such peculiar attention to it, in this which may be eminently called the theological Gospel,-_for this, we might reverently conjecture, if we did not know, some deep theological reason must probably exist. As it is, the knowledge of the reason is vouchsafed to us; it is indicated in the Scripture quoted. The saying, "A bone of Him shall not be broken," carries with it the sacrificial character of our Lord's Passion, that it was the very antitype of slaying the Paschal lamb. And again, "They shall look on Hin whom they pierced" is the prophetic declaration of the mode of applying His Passion to the remission of His people's sins: the "piercing" is the opening of "a fountain for sin and for uncleanness;" and it is signified that it would not take full effect until the Lord had " poured out upon the house of David, and upon the inhabitants of Jerusalem, the spirit of grace and of supplications;" i.e. until a beginning had been given to Christian baptism by the descent of the Holy Ghost upon the apostles gathered on Mount Zion, and the setting up of the kingdom of heaven.

And the rationale, the principle of all this, is shadowed out in the farewell letter of the same Erangelist: "This is $\mathrm{He}$ that came by water and blood, even Jesus Christ; not by water only, but by water and blood. And it is the Spirit that beareth witness, because the Spirit is truth. For there are three that bear record in heaven, the Father, the Word, and the Holy Ghost: and these three are one. And there are three that bear witness in earth, the spirit, and the water, and the blood: and these thrce agree in one. If we receive

d S. John xix. 35. 
the witness of men, the witness of God is greater: for this Cirsp. II. is the witness of God which He hath testified of His Son." What is this threefold witness, this witness of God, on which the Apostle would thus unreservedly rest our faith? It is Jesus Christ, God inearnate, coming to His Church, and to each one of us, by water, by blood, and by His Spirit. To His whole Church He came by water, when, as the surety and representative of His people, He was baptized by S.John in Jordan; by blood, when He died on the cross; by His Spirit, on the Day of Pentecost. To each several child of Adam, whom He takes out of the world as one of His own, He comes by all three at once-by the Spirit, by water, and by blood,-in His two Sacraments, the one as well as the other: for water in Scripture signifies sanetifieation and cleansing; blood signifies satisfaction and atonement; and both these are, by His ordinance, in both the Sacraments, because in both the true gift is Partieipation of Christ, our life and our all, begun in Baptism, continued and growing in the Eueharist. And they are in the Sacraments by the speeial operation of His Spirit: "It is the Spirit that beareth witness, because the Spirit is Truth." The Spirit is that Truth which both declares and makes them to be what they signify, as our Lord declared of one of then: "The words that I speak unto you, they are spirit and they are life;" the words in this case being, for the one, "This is My Body ;" for the other, "I baptize thee in the Name of the Father, and of the Son, and of the Holy Ghost." And accordingly the Church, cxpressly or virtually, has always prayed for this descent of the Holy Ghost,-in Baptism, to "sanetify the water to the mystical washing away of sin ;" in Holy Communion, according to the old Liturgies, to make the elements what our Lord declared them to be; aecording to our own Liturgy, to make us, reeeiving them, partakers of those holiest things.

To this doctrine, probably to expressions of it even then in liturgical use, the Apostle alludes more than once: "By one Spirit are we all baptized into one Bodye." And clse- 
Cuap. II. wheref the Church service is described partly by the use in it of Psalms and hymns in the way of response (so we may best understand "speaking to yourselves,") partly by its involving a continual sacrifice of thanksgiving, and that for all, in the Name of Christ, to the Father,-a definition of a Christian Liturgy, as far as it goes, critically exact.

We may add the often-quoted passage in Rom. xv. 16: "That I might be a minister of Jesus Christ unto the Gentiles, doing a priest's work in respect of the Gospel of God ${ }^{g}$; that the offering of the Gentiles might be acceptable, being sanctified by the Holy Ghost;" where S. Paul represents his calling as a missionary by an image borrowed from his other calling as a priest, the body of Gentile Christians being that which he had to offer, and requiring, in order to be acceptable, sanctification by the Holy Ghost, as the proper sacrifice of Christians did.

In a word, the patristical doctrine, that the Incarnation is not only applied, but extended as it were, by the blessed Sacraments, supplies the sufficient and only interpretation, both of the mysterious opening of the Redeemer's side on the cross, when He was in the sleep of death, and of that which is always referred to by antiquity as the ordained type of that circumstance in the Passion, the piercing of the first Adam's side in his sleep, and the formation or building up of that which was taken out of it into the first woman, his spouse, and the mother of us all.

And (it is a serious and alarming thought) if there be any who now scorn the doctrine, wilfully I mean, and in spite of helps to know better, we know for certain that they will not always scorn it. Holy Scripture tells of a moment to come, when that wound in our Lord's side, the fountain of Sacraments, and the door of life to us all, will be openly seen by all. "Every eye shall see Him, and they also who pierced Him:" even they who, by abusing His Sacrifice and Sacraments, shall have crucified and pierced Him afresh.

f "Speaking to yourselves in Psalms and hymns and spiritual songs, singing and making melody in your hearts to the Lord; giving thanks always for all things unto God and the Father in the Name of ourLord Jesus Christ." -Epl. v. 19, 20.

$\mathrm{g}$ iє $\Theta \in \circ \hat{v}$. 
The sear in His side will be to them an especial condemna- Crap. II. tion, as it will be a pledge of grace received and not wasted to all penitent and devout receivers. It is S. John again to whom this was revealed ${ }^{\mathrm{b}}$; the disciple whom Jesus loved is throughout, by special Providence, the great teacher of the doctrine of His life-giving Body, and of the devotion due to it.

§32. But whatever beginnings of high and hopeful thought the miracle of the water and blood may have occasioned in S. John's mind, to the outward eye the blessed Body was still in the lowest and most pitiable condition,-in the hands of enemies, exposed to the worst indignities,- - until the moment when Joseph of Arimathea begged it of Pilate. This must have been an hour or two after our Lord's death; for He gave up the Ghost at three, P.M., and, although the Sabbath did not begin until six, it seems that the taking down from the cross, the wrapping in linen clothes with the spices, and the entombment itself, had to be somewhat hastily performed. Some time, therefore, had probably elapsed between the piercing of Christ's side and the application of Joseph to Pilate; and since Nicodemus was near, a colleague of Joseph's, and known to have looked favourably on Christ, it is not perhaps exceeding the bounds of reasonable conjecture, if we suppose S. John to have applied to him, and through him to Joseph, whose own new tomb was known to be near at hand, but who was not yet known for a favourer of our Lord, as Nicodemus was, and therefore, perhaps, less obnoxious to the Pharisees. And so, between them, though according to His condescension, our Lord's grave would have been "with the wicked," yet He was "with the rich in His death" and obsequies; unintentional testimony being thus borne by Pilate and others of His persecutors, that " He had done no violence, neither was any deccit in IIis mouth."

Whatever the process may have been, whether it originated with S. John or no, we know for certain that, from that moment forward, His true servants have never ceased to shew, in all possible ways, their entire derotion and love to that Blessed Body, enhanced beyond measure by all that they

h Rev. i. 7. 
Chap. II. were permitted to see and know of Its mysterious agonies; and never was one word uttered from above to stay or check them, or imply that they were going too far. When Cornelius fell down at S. Peter's feet to worship him, he was told, "Stand up; I myself also am a man." When S. John did the like to the angel who was shewing him the heavenly vision, he was stopped by what, among men, would have been an exclamation of religious horror: "See thou do it not: I am thy fellow-servant, and of thy brethren that have the testimony of Jesus: worship Godi." But nowhere in Holy Scripture will you find anything at all answering to this in respect of the worship and reverence shewn to Christ's Body, as if it were possible to exaggerate or earry it too far; not one letter or syllable to interrupt or moderate the deep devotion of the Church for all these centuries that she has remained, with the beloved disciple, standing by the Cross, and with adoring love and wonder contemplating the blood and water as it flows from His pierced side; seeing it, and bearing record,-and her record is true, and she knoweth that she saith true, that we all might believe.

What, indeed, is the history of the three days of Christ's burial, and of the forty days after His resurrection, but a course of solemn acts of worship to His real Bodily Presence, offered on His servants' part and accepted on His own?

There are Joseph and Nicodemus, and the holy women, laying Him in the grave with their myrrh and spices, such as they knew that the Holy Ghost, by the prophets, had appointed to be offered to the King's Son.

There are the Maries coming to the sepulchre in the early morning to complete their religious purpose, and she first who loved best: and they have a great reward-they are permitted to be the first to see His risen Body, and hear His voice; and as soon as they see and hear, they worship; and so (as has becn often noted) they obtain the privilege of preaching the Gospel of the Resurrection to the very Apostles themselves.

There is S. John, who by his presence beneath the Cross, and when our Lord's side was pierced, may be supposed 
to have learned deeper thoughts of the prerogatives of His Chap. II. Body than were yet familiar to any of the rest. As he was first of the Apostles at the sepulchre, so was he first to believe without seeing, and to recognise our Lord appearing suddenly at a distanee ${ }^{k}$; even as many years afterwards he knew Him by sight through all His glory in the heavens, in the midst of the golden candlesticks, and on the cloud of judgment, discerning "one like unto the Son of Manl." Certainly it is a remarkable faet, that the two most noted and most highly-faroured for their special love of our Lord, the Magdalen and the beloved disciple, should thus be marked out for their especial devotion to His Body.

Then there is His sudden appearance on the road to the two disciples, and His no less sudden vanishing out of their sight, just as their eyes were opened, and they had come to know Him in the act of breaking of bread; a history, the significancy of which in our present argument surely needs no elueidation; as neither do the eircumstances of His last appearance that evening, - the cntry through the elosed doors, the real Body with Its real scars, and Its real participation of meat with them, at the same time that It was visibly breathing His own and His Father's Spirit into their hearts, and audibly giving them that commission which none could give but He that is equal with the Father. Who does not feel, as he reads or hears, a deepening veneration and inward worship of the holy Humanity of Him who thus spake and aeted? How mueh more those who saw Him all along with their eyes! who "looked upon" Him, and "handled with their hands" Him who is "the Word of Life" !"

A week more, and the doubts of S. Thomas are removed by the touch of the holy Body with Its sears, or rather, by that permission to touch It, whereby the timid Apostle might diseern the omniseience of the speaker. With confirmed faith he makes his eonfession, the very confession of devout communicants in all ages,- "It is my Lord and my God." Observe the answer he reeeived, - a blessing, not so immediately for himself as for us, whose trial is, that the same Lord and Christ, the same Son of God Incarnate, is present

k. John xxi. 7.

1 Rev. i. 13 ; xiv. 14.

m $1 \mathrm{~S}$. Joln i. 1. 
Crap. II. with us, and permits us to touch Him, as really indeed, but invisibly, and in a different kind of presence. "Blessed are they now, and blessed shall they all be hereafter, who shall believe and worship as thou now dost, without waiting for the actual sight, which has at last convineed thee." These are not words to make a Christian afraid of believing too much of his Lord's Presence in Holy Communion, or of adoring Him too earnestly.

\$33. Rather it might perhaps not untruly be said, that one apparent purpose of our Lord's abode upon earth during those forty days was, that He might inure them to the faith and contemplation of a certain Presence of His now spiritualized Body among them, occasional only, and in the highest degree mysterious, but in itself most real and blessed, and associated with all the best gifts and fruits of His Incarnation-the evidence and conveyance of the eternal life to which He had risen. This Presence the sacred narrative (we may almost say) studiously connects with the meals which He took with them; as at Emmaus, as He sat at meat with them, He took the loaf, and blessed, and brake and gave to them, recalling to their very eyes the miracle of the five thousand and its antitype-the greater miracle of the Eucharist. The same day, at eveuing, having shewn them ' His hands and His feet, while they yet believed not for joy, and wondered, He said unto them, Have ye here any meat? And they gave Him a piece of a broiled fish, and of an honeycomb. And He took it, and did eat before them ${ }^{\text {n." }}$ The following Sunday, as it may seem, He appeared unto the eleven (Thomas having now taken his place among them) "as they sat at meat." The remarkable appcarance and miracle at the sea of Galilee, related in the last chapter of the last Gospel, and considered by S. Augustine ${ }^{\circ}$ as exhibiting a kind of link or transition from Christ's earthly to His heavenly kingdom, had for its visible and immediate occasion the present hunger and destitution of the disciples. They had caught nothing that night; the morning light

n S. Luke xxiv. 40--43.

- In S. Joan. Evang. Tr. 122 :"Narratur hic quemadinodum se manifestaverit Dominus ad mare Tiberia- dis, et in captura piscium commendaverit Ecelesie Sacramentum, qualis futura est ultima resurrectione mortuorum." 
shewed Him to them standing on the shore, but not, as yet, Снар. II. recognised by them. He enquires of them, "Children, have ye any meat?" They answer, No. He tells them where to cast their net; they obey, and in a moment it is full of great fishes; and not only so, but, before they could land any of these, their condescending Lord had provided for them "a fire of coals, and fish laid thereon, and bread ;" and His word is to them, "Come and dine ;" or, in more modern language, "Take your morning meal." Then, and not before, the disciples knew that it was the Lord. It was the third time of His shewing Himself to any number of them together, and each time had been at a meal.

The whole transaction looked back, as it were, not only to the similar miracle, the former extraordinary draught of fishes provided for the same persons on the same waters, but also to the two instances of supernatural feeding, when the hunger of those coming to Christ was satisfied by a few loaves and fishes. And did it not look forward also to the state of things shortly to take place in the Church? how that in our spiritual toil and hunger He would shew Himself to us by glimpses of His blessed Body ; standing on the shore, i. e. Heaven, and calling on us from time to time to partake of the hearenly food He hath provided for us, until the whole Church, the net full of great fishes, a hundred and fifty and three, (the perfect number of the elect,) be drawn after Him to the land, and the Bridegroom, with them that are ready, go in finally to the marriage-feast.

Perhaps it was not without meaning of this kind that the Holy Ghostp, describing the intercourse of Christ with His disciples during those forty days, selected a word 9 which (whatever its derivation) was evidently associated by the early Greek Christians with the idea of fellowship in meals. Forty days, in the symbolical language of Scripture, would represent the whole time of the Church's probation, until the day come in which she shall ascend with her Lord: and then His partaking of her banquet, or, (according to one

P Actsi. 4.

q $\sigma u \nu a \lambda เ \zeta \delta \mu \in \nu o s, "$ being asscinbled together with them;" marg. " eating together;" Vulg. " conveseens;" cf. S.
Chrys, Ecum. Theophylact. in loco; S. Chr. in S. Joan. Hom. S7, Kd. Sav. ii. 925; 'Theodoret, Eranistes, Dial. ii. t. iv. 119. 
Crap. II. interpretation), "eating salt with lier," would denote His presence at the celebration of the great sacrificial feast of the new covenant, which $\mathrm{He}$, in His unspeakable condescension, accounts Himself partaker of with us: as when $\mathrm{He}$ says, "I will not any more eat thercof until it be fulfilled in the kingdom of God";" "I will drink no more of the fruit of the vine mutil that day that $I$ drink it new in the kingdom of God s." For Ilis "meat is to do" His " Father's will, and to finish His work ";" and where on earth is the Father's will and work more perfectly found than in holy and devout Communion? There, if any where on this side heaven, is the "very image of" those "good things to come," which the gracious Lord encourages us to look on to in those words of unutterable condescension, "Blessed are those servants, whom the Lord when He cometh shall find watching: verily I say unto you, that $\mathrm{He}$ shall gird Himself, and make them to sit down to meat, and will come forth and serve them "."

$\S 34$. Then came the day of the Lord's Ascension, when His natural but now glorified Body was to go up to His Father's right hand, there to abide, in its visible form and substance, until the times of restitution of all things. As they saw His Body in the act of departing, "they worshipped ";" He left them prostrate, or on their knees. Very strange it would have seemed to them, had they been told that His sacred Body was the less to be worshipped because it is now glorified, and must wear a veil over it to be endured by mortal sight. And when the Holy Comforter had come down upon them, and they were admitted fully into the kingdom of heaven; besides their knowledge, now made perfect, of all doetrine connected with the Ascension, they would find, in the visible prerogatives with which both themselves and others through them were endowed, fresh reasons every hour for magnifying the holy Humanity of Christ, divinely ordained to be all in all to them. For by their communion with Him through His Spirit, as His chosen and select witnesses, chief members of His mystical Body, the

S. Luke xxii. 16. "S. Luke xii. 37 .

s S. Mark xiv. 25. t S. John iv. 34 . v S. Luke xxiv. 32 . 
works that He had done they were enabled to do also; and Синp.II. for the more confirmation of this union, they were authorized to use the very words and gestures which their Lord had commonly employed in His miracles of healing. This began with the very beginning of the Church, on the Day of Pentecost; but the first instance particularly recorded is the healing of the lame man by S. Peter, in which there is the same combination of the divine Touch and the divine Word as in the majority of our Lord's own miracles, and also in the outward and visible parts of His Sacraments: the Touch, in that the Apostle took the patient " by the right hand and lifted him up ;" the Word, in his saying, "In the Name of Jesus Christ of Nazareth, rise up and walk x." So we read afterwards, that "by the hands of the Apostles were many signs and wonders wrought among the peopley ;" that Ananias laid his hands upon Saul, and he recovered his sight; that S. Peter gave Tabitha his hand to complete her recovery after he had wakened her from death, besides saying, "Tabitha, arise;" that S. Paul, upon the sudden death of Entychus, went down, and fell on him, and embraced him, saying, "Trouble not yourselves, for his life is in him ;" recalling the remembrance of what Elijah and Elisha had done, and intimating to thoughtful persons the typical significance of their history, (and that miracle, we may observe, took place during a celebration of the holy Eucharist): lastly, in Melita he cured a fever by prayer and laying on of hands.

Moreover, from the members, as from the Head, of the Church, it was noticed that the healing virtue did, as it were, overflow, communicating itself to their garments, and those even apart from their persons. From Panl's body "were brought unto the sick handkerchiefs or aprons, and the diseases departed from them, and the evil spirits went out of them." And in Acts v., still more remarkably, "they brought forth the sick into the streets, and laid them on beds and couches, that at the least the shadow of Peter passing by might ovcrshadow some of them." The exceptions also to the rule of healing by touch appear to be of the 
Chap. II. same kind as those which have been noted in the Gospel history: they are, the casting out devils; the infliction of punishments, as in the case of Ananias and Sapphira, and of Elymas; special faith, affirmed in the case of the cripple at Lystra, and implied in that of Aneas; and all in that one only Name, whereby it might be known without question that Christ is the only Healer, as $\mathrm{He}$ is known to be the only Baptizer and the only Consecrator. Who can doubt that the effect of all this was still to deepen men's reverence and gratitude towards the awful and blessed Body which they knew to be the fountain of it all? which Body, be it noticed, was every day presented before them in a sacramental way in the holy Eucharist; for in the mother Church of Jerusalem, at least, we know that they "continued daily in breaking of bread."

$\S 35$. We may perhaps not unfitly close this series of scriptural faets by noticing that it is the Lamb which is selected, rather than the Lion, or any other animal, as that symbol of our Lord which may most meetly represent Him in His celestial estate, all through the Book of Revelations; in part, doubtless, for the same reason that the Cross is His chosen standard among inanimate things, and the Son of Man His chosen title: that wherein $\mathrm{He}$ abases Himself most, or is most evil spoken of, therein He may receive especial glory.

And the general result of the survey comes, I think undeniably, to as much as this-that every where such encouragement is given to the worship of our Lord in His human nature, made adorable by its union with the Divine, as to create a strong probability, at least, that such worship would not be forbidden, but rather sanctioned and enjoined, in that Sacrament which, rather than any thing else, is the standing monument of the Incarnation, and extension of it.

$\S 36$. And such, in fact, is the case, as a very few words will shew. Worship is a personal thing; the true, real, primary object of worship, in the proper and high sense of the word, for all reasonable and understanding creatures, must of course be some personal Being, and that Being the Most High God. On this point there is no need of any abstract 
discussion; it is settled for us at once on the very highest Crap. II. authority: "Thou shalt worship the Lord thy God, and Him only shalt thou serve." The Person therefore of Jesus Christ our Lord, wherever it is, is to be adored-to be honoured, acknowledged, sought unto, depended on, with all possible reverence, with the most entire and single-hearted devotion, incommunicable to any finite being-by all creatures whom He has brought to know Him. This proposition, though in the heat of theological warfare it may seem to have been denied, and that recently, cannot, I conceive, be really and advisedly denied by any one who believes the Divinity of our Lord. Taking it for granted, I will state it once again. The Person of Jesus Christ our Lord, wherever it is, is to be adored. And now I will add the next proposition in the argument, viz. Christ's Person is in the holy Eucharist by the presence of His Body and Blood therein. From which, as will be seen, follows, by direct inference, that the Person of Christ is to be adored in that Sacrament, as there present in a peculiar manner, by the presence of His Body and Blood.

It is on the second or minor of these three propositions, if on any, that opposition is to be expected, and explanation is necessary. It raises, evidently, the whole question of that which is denominated "the real objective Presence" of Jesus Christ in the holy Eucharist. That is to say, whereas the Divine nature in Christ is everywhere and always equally present, and so everywhere and always alike adorable; but to us frail children of men $\mathrm{He}$ has condescended at certain times and places to give especial tokens of His Presence, which it is our duty to recognise, and then especially to adore: thus far, I suppose, all allow who in any sense believe the Creeds of the Church, that in the holy Eucharist we are very particularly bound to take notice of His divine Presence, as God the Word, and to worship Him accordingly. That which some in modern times have denied is, that He is then and there present according to His human nature, really and substantially present, as truly present as He was to any of those with whom He conversed when He went in and out among us; or again, as lle is now present 
Снар. II. in heaven interceding for us. Both of these two last mentioned are modes of His human Presence, acknowledged by all who confess Him come in the Hesh. But that which some affirm, some deny, as part of the Catholic doctrine of the Eucharist, is a third and special mode of Presenee of the holy Humanity of our Lord, denoted and effected by His own words-"This is My Body, this is My Blood;" a Presence the manner of which is beyond all thought, much more beyond all words of ours, but which those who believe it can no more help adoring, than they could have helped it had they been present with S. Thomas, to sce in His hands the print of the nails; or, again, with so many sick persons to touch the hem of His garment, and so to be made whole. It is no more natural for them to think, one way or the other, of worshipping the Bread and Wine, than it was for the woman with the issue of blood to think of worshipping the garment which she touched, instead of Him who was condeseending to wear it and make it an instrument of blessing to her.

If we may reverently say it, (using an illustration which is applied by the Church to a subject, if possible, still more awful than this,) "as the reasonable soul and flesh is one Man," and as "God and Man is one Christ," so the consecrated Bread and Wine, and the Body and Blood of our Lord Jesus Christ, are one Sacrament. And as we know the soul of a man, which we cannot see, to be present by the presence of his living body, which we can see, so the presence of that Bread and Wine is to us a sure token of the Presence of Christ's Body and Blood. We are not more eertain of the one by our reliance on God's ordinary providence, than we are of the other by our faith in Christ's own word. And as persons of common sense are not apt to confound a man's soul with his body, because of the intimate and mysterious connection of the two,-(to bring men to that requires either extreme subtilty or extreme grossness of understanding);nor yet can you casily bring them to doubt whether meat and drink serve to keep the two together, whether life can come by bread, because they cannot understand how,-so no plain and derout reader of Holy Scripture and disciple of the 
Church would, of his own accord, find a difficulty in ador- Cнат. II. ing the thing signified, apart from the outward sign or form; or in believing that the one may surely convey the other by a spiritual and heavenly process, known to God, but unknown to him, and to all on earth.

$\S 37$. It is not the object of these papers to reason out at large that great, and comfortable, and ( $\mathrm{I}$ will add) necessary truth, known to the faithful under the name of "the Real Presence," but rather to point out the inseparable connection between it and the practice of adoration. But I must here borrow so much from the premisses of that argument as to assume that the sixth chapter of $\mathrm{S}$. John really and primarily relates to the Sacrament of Holy Communiou; according to the well-known interpretation of Hooker, which is the interpretation of all antiquity, and lies so obviously on the surface of Scripture, that one can hardly conceive a simple, unlearned reader giving any other turn to the discourse in that chapter, unless he were prepossessed by a theory.

Allowing, then, that, as Hooker alleges, the Apostles at the Last Supper could not but understand the sayings and doings of our Lord as the intended fulfilment of His typical miracle and prophetic sayings a twelvemontl before, let us calmly consider what doctrine about Holy Communion they must have taught and believed, from that day forward, or at least from the day of His coming upon them Who was to bring all Christ's sayings to remembrance. 'They must have believed that, as ordinary food and drink are necessary to ordinary temporal life, so His Body and Blood, sacramentally received, are necessary to spiritual life; for " except ye eat the Flesh of the Son of Man, and drink His Blood, ye have no life in you :"-that as a common meal, with God's blessing upon it, has a virtue to keep us alive for a certain time, so this heavenly meal has the like virtue in respect to the life everlasting; for "whoso eateth My Flesh and drinketh My Blood hath eternal life:"-that it has a certain special quality of preparing our bodies for the general resurrection ; for "I will raise him up at the last day ;"'-that ordinary food and drink is but the shadow of this, the true Bread from heaven, and 
CHAp. II. the fruit of the true Vine, in the same kind of way that Christ is the true Light, and this material light but a figure of Him; heaven the true riches, of which the earthly mammon is but a coarse and unreal image; and all other Gospel antitypes far more real and substantial than their legal or natural types: for which cause, mainly, (as I suppose,) Christ is called the Truth, in contradistinction to Mosaical shadows; so that in the Sacrament we eat and drink more really and substantially than on any other occasion :-all this they might gather from the saying, "For My Flesh is meat indeed, and My Blood is drink indeed."

Again, they would understand that His Flesh and Blood in Holy Communion is the special means appointed by Him, not for beginning, but for continuing, spiritual life, - the instrument whereby the members adhere to their Head,-as well as the remedial token and pledge whereby they know that they are very members incorporate in Him, and not yet cast off for their many backslidings; for "He that eateth My Flesh, and drinketh My Blood, dwelleth in Me, and I in him." Finally, to set the most awful seal to the greatness and reality of all this,- - to put down for ever the notion that He was merely using figures of speech,-the Holy Ghost caused them to remember that our Lord had said, "As the living Father hath sent Me, and I live by the Father: so he that eateth $\mathrm{Me}$, even he shall live by $\mathrm{Me}^{\text {a." }}$

$\S 38$. And for a key to the whole mysterious transaction, so far as man might comprehend it, He had introduced the title, Son of Man, three times in the course of the conversation, and apparently just at those points of it where it would come in most significantly, supposing His intention to be to intimate thereby the office of the Sacrament in extending and applying the benefit of His Incarnation.

First, in leading His hearers to the whole subject, He had said, "Labour not for the meat which perisheth, but for that meat which endureth unto everlasting life, which the Son of Man shall give unto you: for Him hath God the Father sealed b." Him the Father had "sanctified and sent into the world," anointing His holy Manhood with the Holy Ghost

$$
\text { a S. John vi. } 57 .
$$

b Ibid. 27. 
and with power without measure, for this especial purpose, CBAP. II. that He, bcing the Sou of Man, might give us the meat that endureth unto everlasting life.

Secondly; when in His gracious disclosures, keeping even time (so to speak) with the stubborn and insolent answers of the Jews, He had arrived at that saying, so offensire to the ear and heart of philosophy falsely so called, "The Bread that I will give is My Flesh;" it began, as soon as spoken, to be a cause of strife : for in regard of this doctrine especially has the saying ever been too truly fulfilled, "I came not to send peace on the earth, but a sword." And accordingly the Jews, at the very first hearing of it, began to strive with one another, saying, "How can this Man give us His Flesh to eat c?" Whereupon our Lord, in repeating it, with the addition that they must drink His Blood, was careful to point out to them that it was the Flesh and Blood of the Son of Man: Except ye eat the Flesh of the Son of Man, and drink His Blood, ye have no life in you." As Son of Man, He had decreed to bestow on them His Flesh and Blood, that it might be within them, to be the very life of their souls.

Once more, when the trial and agony caused by the "hard saying d" seemed at the keenest, in His prophetic mercy and pity He warned them of au event which would make it harder still: "What and if ye shall see the Son of Man ascend up where He was before?" He accompanied the warning with a significant repetition of the titlc, Son of Man; which, when the time was come, His disciples would understand to imply that Ilis going up to hearen bodily, in His human nature, was indeed a most essential link in the chain of wonders which began with His Incarnation. His work as Son of Man would be very incomplete without it; He could neither sit as a King on His Father's right hand in heaven, "until His enemies be made His footstool," nor stand before Him, either there or in earth, as "a Priest fol ever after the order of Melchisedcc." Since the commemorative Sacrifice in hcaven was necessary for the efficacy of the Eucharist offered on earth,-which, indeed, is only efficacious by bcing joined to the oblation above,-the Communion, howerer 
Crap. II. blessed a thing, cannot be understood as having done all its work before the glorious Ascension of our Lord. Mary must not touch Christ, because Ile hath "not yet ascended to $\mathrm{His}$ Father," to send down, as the first-fruits of His priestly office in heaven, the Holy Spirit, by Whose regenerating power mortals might be united to Him, and made worthy to touch Him spiritually. Such is S. Cyril's cxposition of that mysteriuus saying, "Touch Me not, for I am not yet ascended to My Fathere." And if any one hesitate to accept it, as inconsistent with our Lord's offering His Body, as He did so often, to the touch of His disciples during those forty days, he may consider that such permission was granted, by way of miraculous evidence, to such as were yet imperfcct in the faith of the Resurrection; whereas the blessed Magdalene seems to have had no doubt, but only wanted to kiss His feet, as before His death, in loving adoration. Her touch would represent the ordinary approach of believers to Christ's Body in the holy Eucharist, and was therefore to be deferred until she had been purified by the Holy Ghost.

To return for a moment to His own words in the sixth chapter: "What and if ye shall see the Son of Man ascend np where He was before?" Understood in this connection, they do in a wonderful manuer intimate the three great mysterious Uuities comprised in the idea of Christian redemption: first, the Unity of the Father and the Son, implied in "where He was before;" next, the Unity of God and Man in the Person of Christ, implied in the title, Son of Man; thirdly, the Union and Communion between Christ and His saints, in that partaking of His Body and Blood is here connected with His Ascension. And in the next verse He turns our thoughts towards that other Divine Person, Who, as Holy Scripture informs us, is in some heavenly way the bond and principle of each of these divine unities. "It is the Spirit that quickeneth." The Holy Ghost, the Lord and Giver of Life, of Whom the Church says " that " in His unity" the Son liveth and reigneth with the Father; and Whom our Lord, speaking to the Father, seems in one place to entitle, "The Love wherewith Thou hast loved Mes;" by

e In S. Joan, xx. 17. t. vi. 1084-1086. Ed. Aubert.

t Collect for Whitsunday.

g S. John xvii. nit. 
Whose power, overshadowing the blessed Virgin, the God- Crup. II. head and Manhood were united for ever in Christ:- He it is that quickeneth the souls and bodies of men dead in tres. passes and sins: He also (so our Lord seems to speak) shall descend upon the earthly creatures which I by My priests shall bless, and cause them to be the Flesh and Blood of the Son of Man, life eternal to those who go on worthily receiving them. "The flesh profiteth nothing :" not even the Body of the Lord Jesus Christ, could you conceive it separated from His divine Person and Spirit,-much less the Bread and Wine used as a charm,- - could ever do your souls any good: any such superstition or witcheraft could only come of this earth, or worse; but "the words that $I$ speak unto you, they are spirit and they are life."

But whatever turn may be given to this verse in particular, certainly there is nothing in the above-mentioned way of stating the general drift of that chapter of S. John, but what the words will very well admit of: nothing unwarranted by the testimony of the ancient Church: and the mere statement of it shews sufficiently what an exact analogy it bears to the Scriptural accounts of the other portions of the divine process of salvation,- - how naturally it finds its place among them.

$\S 39$. Now to apply all this to the question of adoration: is the Person of Christ, God and Man, present in the holy Eucharist by this transeendental Presence of His Body and Blood? The affirmative seems distinetly proved by His own words in the same discourse; in that He more than once interchanges the first personal pronoun, I, Me, \&c., with the phrases, "This bread, My flesh," \&c. I will not dwell on the 32nd and 33rd verses ${ }^{\text {h}}$, which in our English translation would seem to exemplify this; for it may be that the sentence which is rendered, "The Bread of God is He which cometh down from heaven, and giveth life unto the world," should rather be rendered "that which cometh down from heaven ;" althongh the word "giveth" strongly suggests the idea of a person acting, and is distinctly so employed

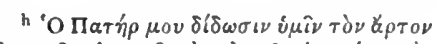

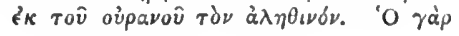

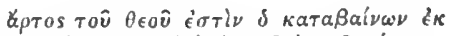

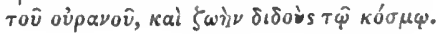


64 The Bread of Life, being Christ IIimself, is adorable.

Chap. II. throughout the New Testament, with two exceptions only, and those of a poetical cast: "the moon shall not give her light ;" and, "the heavens gave rain i."

But be this as it may, two verses further on our Lord distinctly identifies the Bread of Life with His own Person: "I am the Bread of Lifej." And so the Jews understood Him, for they murmured at His saying, "I am the Bread which came down from heaven ;" and He, instead of eorrecting, confirms their thought, re-asserting more unequivocally, more at large, and in a more startling form, the truth at which they had taken offence, and leaving it with them, and with all His hearers, to be an occasion of falling to the one sort, a wholesome exercise of faith to the other. "I am that Bread of Life," He repeats ; " $\mathrm{I}$, in My Person, Jesus Christ, God and Man." "Of Life:" in that while "your fathers did eat manna," which was called "Bread from heaven," "and are dead, this is the Bread that cometh down from Heaven, that a man may eat thereof and not die." Then, as if to preclude the notion that the bread He was speaking of was any mere gift of His, anything short of participation of His very Self, He proceeds to qualify that Bread as living, and as having come down from heaven: "I am the living Bread which came down from heaven;" not life-giving only, but living;

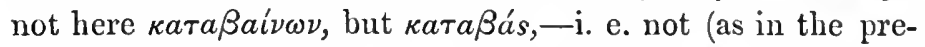
ceding verse) coming, as it were, mystically down, from time to time, on each sacramental occasion, but having once for all come down by the wonderful Incarnation; on which descent plainly depends the word of pronise immediately following: "If any man cat of this Bread, he shall live for ever." And to complete the statement, and bring the Sacrament which $\mathrm{He}$ was to institute into closest connection with His own Incarnate Person, He subjoins, "And the Bread, moreover, (кai $o$ ă $\rho$ тоs $\delta \grave{e})$ which I will give is My Flesh, which I will give for the life of the world." (The $\delta \dot{\epsilon}$, which in this phrase indicates the insertion of a new circumstance in the statement, is overlooked in our version.) His Flesh, then, in this argument is plaiuly Himself, and the sacramental Presence, oblation, and participation of the one are respectively those of the other.

IS. Matt. xxiv. 29; S. James v. 18.

j Ibid. 35 : cf. $41,48-51$. 
The same is again implied (may we not say, clearly as- Crrs. II. serted ?) in the concluding portion of the dialogue. "Whoso (v. 54) eateth My Flesh and drinketh My. Blood, hath etemal life; and I will raise him up at the last day ;" is repeated (v. 57) in this form: "He that eateth $M e$, even he shall live by Mc." The "Me" in this sentence is clearly equivalent to "My Flesh" in the former one. Therefore such as eat His Flesh and drink His Blood worthily in Holy Communion are indeed partakers of the Son of God by a true supernatural union, and derive from Ihim eternal life; as really as $\mathrm{He}$ is partaker of the Father, by that ineffible, incommunicable Sonship, and being for ever God of God, Light of Light, very God of very God, -the Second Person, not the First,-derives from Him, who is the First, life and being, and all that He hath; and is God, not by adoption, but by eternal generation. What man or Angel durst have spoken such a word? but now it is put into our months by the Creator of men and Angels, and we dare not refrain from speaking it.

Therefore, again, (how can we help the conclusion? and why should we shrink from it?) where His Flesh and Blood are, there is IIe by a peculiar and personal Presence, in Iis holy Humanity; and being there,-being, as First-begotten, so brought continually into "the habitable parts of His carth," according to the "delight" which He has in being "with the sons of men,"-He must needs be adorable, both by the holy Angels and by the children of men themselves, whom He comes to quicken and to bless for ever.

$\S 40$. The points on which this argument turns are expressed in few and well-known words by S. Ambrose, near the end of his Tract on the Mysteries, not as his own teaching, but as the teaching of the Church $k$. First, of the real and substantial Presence after Consceration thus he writes:

"The Lord Jesus Himself cries out, This is My Body. Before bencdiction by the heavenly words, it is named by the name of another kind of thing; after consecration it is significd to be a Body. He Ilimself calls it 'His own Blood.' Before consccration it is called sumething else; 
Снит. II. after consecration, its style and title is Blood. And thou sayest, Amen; that is, it is true. What the mouth speaketh, let the mind inwardly confess; what the discourse utters, the same let the heart fecl."

Next, as to the Presence being personal, by reason of the Presence of His Body:- "The Church, beholding so great grace, exhorts her children, exhorts all around her, to run together to her Sacraments, saying, Eat, ye who are nearest unto Me, and drink, and be inebriated, O my brethren ${ }^{1}$. What we eat, what we drink, the Holy Spirit in another place hath explained to thee by the prophet, saying, O taste and see that the Lord is sweet: blessed is the man who trusteth in Him m." Here the Psalmist is interpreted as signifying that what we taste is the Lord Himself: for S. Ambrose proceeds, "In that Sacrament is Christ, because it is the Body of Christ." And then he warns us,-in words corresponding to our Lord's cautionary saying,- "It is the Spirit that quickeneth; the Flesh profiteth nothing ;" that for this very reason, "because it is the Body of Christ," it is "not bodily food, but spiritual. Wherefore also the Apostle suith of that which is a type of it, that our Fathers did eat spiritual meat, and drink spiritual drink. For the Body of God is a spiritual Body; the Body of Christ is the Body of a Divine Spirit: for Christ is a Spirit... . I may add, that it is our heart which this meat 'strengthens,' and this drink 'maketh glad the heart of man ;' as the prophet points out" in the 104th Psalm.

What was the opinion of S. Ambrose, or rather what his testimony is to the belief and practice of the whole Church in his time, touching the adoration of Clirist sacramentally present, will appear by-and-by.

\$ 41. But the Seriptural argument for it is yet very far from being cxhausted. The Word of God presents to us the Sacrament of the Eucharist under another, a sacrificial, aspect: which must be considered, if the truth is adequatcly to be told concerning cither the Real Presence, or the adoration claimed for it. The Eucharist, as the Fathers

1 Cantic. v. 1.

m Ps. xxxiv. 9. 
speak, is the unbloody Saerifiee of the New Testament; un- Curs. II. bloody, though it be in part an offering of blood: àval-

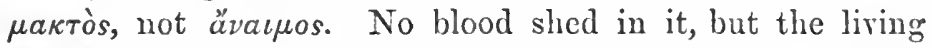
Blood of Christ with His living Body oflered up to the Father, for a memorial of the real blood-shedding, the awful and painful Sacrifice onee for all offered on the Cross.

This memorial Christ offers in heaven, night and day, to God the Father: His glorified Body, with all its wounds, His blood which He poured out on the eross, but on Ilis resurrection took again to Himself, and with it aseended into heaven. With that Body and Blood He appears continually before the throne, by it making intercession for us; by it reminding God the Father of His one oblation of Himself once offered on the cross: as S. John writes, "We liave an Adrocate," one to plead for us, "with the Father, and Ife is the Propitiation for our sins." Thus $\mathrm{He}$ is our $\Lambda$ aron first, and then our Melchisedec; the virtue of His perpetual advocacy depending on His former propitiation. Both ways He is "a Priest for ever."

$\$ 42$. But to enter on a regular exposition of this great evangelical truth would involve a detailed eommentary on large portions of Holy Scripture, and the whole system of ancient sacrifices would have to be thoroughly and minutely analysed. For the present undertaking it will suffice if we can shew,

First, that the doctrine of the Eucharistical Sacrifice is involved in the very words of institution, and is of course inseparable from the true meaning and right use of the Sacrament. In which argument it will incidentally appear that the English Liturgy in particular is full of the same doctrinc.

Secondly, that there are large portions of the New Testament which cannot be explained without assuming it.

And as we go along, we shall see how evidently the faet of Christ's Eucharistical Priesthood implies the duty of constantly adoring IIim in the Eucharist.

$\S 43$. First, then, of the Words of Institution, and the turn given to them in our Communion Office.

The places, it is true, are not many, but they are decply significant. The key-words in them (so to speak) are such 
Cпip. II. as remembrance, memory, memorial, all which refer us of course to one of the words of institution: "Do this in re-

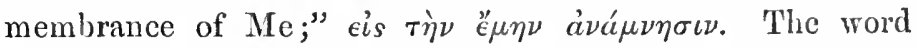
ává $\mu \nu \eta \sigma \iota s$ is a sacrificial word, as may be seen in Leviticus ii., and elsewhere, as well as the kindred word $\mu \nu \eta \mu$ ó vvov; and when so applied, means always "something offered to Almighty God, to remind Him" of the worshipper himself, or of some other person or object in whom the worshipper takes an interest; or of His own loving-kindness, shewn by mercies past or gracious promises for the future.

Such memorial offerings in sacrifice are like the memorial words in prayer: e. g., "Remember Abraham, Isaac, and Israel, Thy servants" ;" "Remember me, O my God, for good ${ }^{n}$." Or like that which is the conclusion of almost all the collects which we address to God the Father,_- "through Jesus Christ our Lord." That short form is in words what the Christian memorial Sacrifice is in act and deed; pleading with the Father by Christ erucified; presenting to Him the Body and Blood of His Incarnate Son, with all His wounds, and all His merits and mercies, that in Him and by Him we may be accepted; that the remedy provided for all may be applicd to, and taken by, each one in particular. This is the proper drift of the word remembrance in our Lord's institution of the Sacrament. "Do this ;" He seems to say, "Bless, break, distribute, receive, this Bread; bless, distribute, drink of this Cup; say over the two respectively, "This is MIy Body, this is My Blood;' in order to that memorial sacrifice which properly belongs to $\mathrm{M}$ e ; the memorial which $\mathrm{My}$ servants are continually to make of $\mathrm{Me}$, among one another, and before My Father." Not, of course, as though He could forget, or needed, like the heathen idols, to have His attention recalled to His worshippers, (as Elijah said of Baal, "He sleepeth, and must be awaked ;")-far be it from any Christian to charge his brethren with such an unwortly superstitious notion; but as it is with the omniscient God in the matter of prayer, so in this matter of sacrifice. He knoweth what we have need of before we ask, get He willeth

D Exol. xxxii. 13; Isa. lxiv. 9.

- Nehem. xiii. 31; Ps. lxxiv. 2, 18; Ps. Ixxix. 8. 
us to ask: so He might without any offering of ours apply Cнur. II. to us the benefits of our Lord's Sacrifice, but it hath pleased Him to ordain this way of memorial sacrifice, - a most blessed way for us, in that we are hereby permitted to join in that very same memorial of our dear Lord's Death and Passion, which $\mathrm{He}$ is now and always making of it within the true holy of holies, and before the true mercy-seat.

$\S 44$. Theologians, indeed, have not seldom said that the Christian dispensation has no standing sacrifice, properly so called: thus Hooker, "The Fathers of the Church of Christ call usually the ministry of the Gospel priesthood, in regard of that which the Gospel hath proportionable to ancient sacrifices, namely, the Communion of the blessed Body and Blood of Christ, although it have properly now no sacrificep." This passage undoubtedly does in words contradiet the saying that the Eucharist is the "Christian Sacrifice;" but on second thoughts it may, perhaps, be found substantially to assert the doctrine contained in that saying. "The Gospel," he says, "hath properly now no sacrifice;" i.e., no such sacrifice as had been mentioned just before, under the title of "ancient sacrifices;" no material offering solemnly ordained for the known ends of saerifiees. This we all grant; it is the very same statement which the same Fathers were in the habit of making, when they were explaining the principles of Christianity to the heathen, so far as their rule permitted. Take, for instance, the words which Prudentius puts into the mouth of the martyr Romanus: :-

"Cognostis Ipsum; nunc colendi agnoseite

Ritum modumque: quale sit templi genus,

Quæ dedicari sanxerit donaria,

Quæ rota poseat, quos sacerdotes relit,

Quod mandet illic nectar immolaricr.

Edem sibi Ipse mente in hominis condidit; ....

Illie sacerdos stat sacrato in limine,

Foresque primas virgo custodit fides. ...

Poscit litari vietimas Christo et Patri, . .

Frontis pudorem, cordis innocentiam, 
Dei timorem, regulam scientix,

Pacis quietem, castitatem, corporis. . . . .

Ex his amonus hostiis surgit vapor, ...

lit prosperatum dulec delectat Deum."

Did Prudentius and others by these and the like sayings imply that sacrifice is no part of the Christian ministry in any sense? surely not.

Prudentius flourished in the latter half of the fifth century; a time in which there can be no doubt of the prevalence of the sacrificial view of the Eucharist over the whole Church. All will allow that the language to which Hooker refers as usual in the Fathers, was by that time at least universally employed, both in liturgies, and in homilies, and other religious compositions. One short sentence in an epistle of S. Augustin and other African Fathers to Pope S. Innocent I. may be taken as a key to their doctrine: "Melchisedec by bringing forth the sacramental sign of the Lord's Table, was instructed low to prefigure His eternal Priesthoodr." How can this be reconciled with repudiation of altars and sacrifices in the statements beforementioned? In this way, if I mistake not,-that the truc oblation in the Christian Sacrifice is in no sense earthly or material. It is altogether spiritual: the chief of those spiritual sacrifices in the offering whereof consists the common priesthood of us all. The Eucharist comprehends them all in one, and has besides, peculiar to itself, that which alone causes any of them to be acceptable. For the true oblation in the Eucharist is not the Bread and Wine,-that is only as the vessel which contains or the garment which veils it;-but that which our Lord by the hands of the priest offers to His Father in the holy Eucharist, is His own Body and Blood, the very same which He offers and presents to Him,-with which, as S.Paul says ${ }^{\text {s }}$, He appears before Him now, night and day continually - in heaven, in commemoration of His having offered it once for all in His Passion and Death on the Cross. It is the one great reality, summing up in itself all the memorial sacrifices of old. In the Christian scheme, it is "proportionable" to them; and of course it stands in the ${ }^{x}$ Ap. S. Aug., Hp. cexxrii. 12.

${ }^{5}$ IIeb. ix. 24. 
same rank and relation to them, as the other antitypes in CнA. II. the Gospel to their several types and shadows in the law.

The memorial therefore made of Christ before the Father in Holy Communion, is as much more real, more glorious, more blessed, than all the memorial sacrifices of old; - than the yearly paschal lamb, for instance; - as the one atoning Sacrifice on the Cross surpassed the lamb slain at the first Passover; as the descent of the. Holy Spirit at Pentecost surpassed the fire on the burnt-offering; as Christ is more glorious than Aaron or Melehisedec; heaven, with the tree of life and the waters of life, more blessed than the land flowing with milk and honey; the new Jerusalem more true and real than the old. He who thinks most highly, and therefore least inadequately, of that holy and divine Sacrament, cannot well say, or conceive, any thing of it higher than this,- that it is, in the strict sense of the word, "that which the Gospel hath proportionable to ancient sacrificest."

Therefore let no person apprehend that in teaching and magnifying the Eucharistic Sacrifice he is really contradicting this great authority; any more than, to name a kindred point, he need think limself departing in principle from Hooker's mind by maintaining the Real objective Presence after consecration. For it is very plain that Hooker's scruple arose not from any dread of so-ealled superstition, as though too much were being attributed to sacraments, but from jealousy in behalf of the doctrine of our Lord's true and abiding Humanity. That doctrine being duly guarded, (as no doubt it is by the Father's' language thoroughly considered,) Hooker evidently would have felt himself free to receive that language in its literal meaning, as acknowledging a Presence most real and substantial, but not corporeal or natural; - not such as would be recognised by the bodily seuse, though the veil were ever so much taken away. The rery passage which Hooker, in stating his difficulty, alleges from S. Augustine, may secm to suggest the solution of it: "The Man Christ Jesus is now in that very place from whence Ile shall come in the same form and

\footnotetext{
' The italies are Hooker's own, in his first edition.
} 
Cinap. II. substance of flesh which He earried thither, and from which He hath not taken nature, but given thercunto immortality. According to this form IIe spreadeth not out Himself into all places." Not in His human form, nor simply in all places "; yet this hinders not, but that His Person may be wherever in His sacramental word $\mathrm{He}$ declares, "This is My Body," by a Presence of His glorified Humanity, literally true, though to us undefinable.

$\S 45$. But if Hooker ought not really to be set down as a denier of commemorative sacrifice in the Eucharist, much less ean our thirty-first Article be so interpreted with any shadow of reason. That Article obviously deals with those sacrifices only for which atoning virtue is claimed, and power to make satisfaction for sin, besides and apart from the offering of Christ on the cross. It does not touch the Eucharistie Sacrifiee, considered as one with that presentation of His crucified and risen Body to the Father, which the Apostle to the IIebrews describes as taking place continually in heaven, for the application of the great remedy to the eleansing of each man's soul and conscience in particular. As in the typical atonement made yearly for God's ancient people, it was no disparagement to the virtue of the sin-offering, that its blood had to be brought by the highpriest within the veil, and applied by sprinkling to the holy places, the priests, and the people; so it is in this case. To say that the sacrificial view of the Eucharist interferes with the sufficiency of the sacrifice of the death of Christ, would in effect be saying that Melchisedec could not be a priest because Aaron was; nay, more,- - that our Lord conld not be our Intercessor in heaven, because Ile had become our Redeemer here by His death.

Now, if the holy Eucharist as a sacrifice be all one with the memorial made by our Iigh-Priest Himself in the very sanctuary of heaven, where $\mathrm{He}$ is both Priest, after the order of Melehisedec, and Offering, by the perpetual presentation of Ilis Body and Blood; then, as the blessed inhabitants of heaven camnot but be thought of as adoring Ilim in both IIis aspects, of Priest and Sacrifice,-so how 
should His holy Church throughout all the world not adore Cuar. II. Him in like manner, as often as she "goeth up to the reverend Communion" to offer up spiritual sacrifices, and "to be satisfied with spiritual meats $\times$ ?" For there $\mathrm{He}$ is in His holy and perfect Manhood, virtually present, as our Priest, with him that ministereth, being one of those to whom He said, "Lo! I am with you alway, even unto the end of the world;" and really present, as our Sacrifice, according to that other word, "This is My Body, and this is My Blood,"-"Do this in remembrance of Me."

$\S 46$. And so the Catechism of the Church of England takes it; requiring for the validity of the outward sign, that it be not only "bread and wine," but that "Bread and Wine which the Lord hath commanded to be received;" i, e. over which Christ Himself hath spoken the words of institution. If any one doubt this construction, he may consider, first, that it would be mere tautology, little to be expected in such a document, to repeat liere what had been plainly and sufficiently set down in the general definition of a sacramentthat it must be "ordained by Christ Himself ;" next, that our view is no more than is required to make the description of this Sacrament equivalent to that which had been given of the other. For, (this section of the Catechism being plainly intended to be framed in exact logical order,) since in the account of holy Baptism, the outward and visible sign or form had been defined both by the Element and the Word; -the element, water; the word, "In the Name of the Father, of the Son, and of the Holy Ghost;"-it was to be expected that there would be a like specification in the case of the holy Eucharist also. But nothing of the sort appears, unless we accept the above-mentioned account of the clause, "which the Lord hath esmmanded to be received." The outward part of the great Sacrament is on that hypothesis defined by its Element only, and no Word at all assigned to it. Whereas on our construction the well-known saying of S. Augustine is precisely kept in view: "Accedit verbum ad elementum, et fit Sacramentum."

Again, this mode of interpretation critically accords with

× Hon. of the sacranent, lst part. 
Cuar. Il. a certain important distinction obscrved all along by the Church in dealing with these two blessed mysteries. The Word or verbal part of the form in Baptism is minutely and unchangeably laid down, but nothing is said or implied of any special qualification in the person speaking it. In the Eucharist, not only are the words of institution (as we take it) peremptorily enacted, but it is also enacted that they must be spoken by Christ Himself, saying in each case over the particular element, "Take, eat, This is $\mathrm{My}$ Body which is given for you ;" and "Drink ye all of this, for this is My 13lood." Thus the Catcchism assumes that it is no true Supper of the Lord, unless the person celcbrating be one expressly authorized to speak the words in our Lord's own Name; as much so as those werc with whom $\mathrm{He}$ celebrated His first Eucharist. This, I say, harmonizes well with the fact notorious in Chureh history, that all Christians, in case of necessity, are empowered to administer holy Baptism, but none may "make the Body of Christ," except those specially commissioned by the Apostles.

Would it be going too far to say that our Church in this sentence simply accepts the idea of one only Consccrator, analogous to that so plainly preached by S. John Baptist, and expounded by S. Augustine, of one only Baptizer? Whereupon it would seem to follow, that in reality there is but one Eucharist; that our celebrations, how innumerable soever, and however widely separated in time and place, are not so many commemorations of that first offering in the upper room, but an actual continuation of it; a continuation of it on earth, the very image (as $\mathrm{S}$. Paul and $\mathrm{S}$. Ambrose speak) of that other and heavenly continuation of it, which began on our Lord's Ascension, and will go on to the end of the world.

This is the theory of the Church's daily Sacrifice. It would be literally continual, if all lands were Christian, and if Holy Communion were solemnized at the same hour in every Christian land. Not as if, accorting to the language of Roman writers, the expiatory Sacrifice on the Cross werc repeated or continued on our altars. 'The Epistle to the Hebrews, and the ancient Church commenting on it, as expressly negative 
any such statement, as they affirm the continuance of the Cirsp. II. pleading commemorative Sacrifice: "The continual remembrance of the Saerifice of the Death of Christ, and of the benefits which we receive thereby."

The Man Christ Jesus, according to the Catechism, is thus virtually present, as the true Consccrator, in our Eucharist. Still more distinctly are we there instructed concerning the real Presence of His Body and Blood in that Sacrament,- to be first our Oblation, and then our spiritual Food. Combining the several statements, they amount to this: the Sacrament of the Lord's Supper, in that it is a sacrament, has always in it two parts, whereof the inward and spiritual part is the Body and Blood of Christ; - and it has two purposes: 1. to be a continual remembrance, or memory, or memorial before God as well as man, not a repetition or continuance, of the Sacrifice of the Death of Christ; 2. to be verily and indeed taken and received by the faithful for the strengthening and refreshing of our souls, as our bodies are strengthened and refieshed by bread and wine. I cannot understand these statements to imply less than a real and substantial Presence of Christ by the Presence of His Body and Blood; nor can I imagine any one believing Him so present, and not acknowledging the same by special adoration.

The rather, since, (if I may revert here to one of the principles laid down in the beginning of this essay,) His Presence here is associated not only with infinite blessings, but also with unspeakable condescension. He comes down in a manner to offer Himself anew for each one of us in particular, receiving Him worthily; and that under the poor and ordinary veil, or form, which we all know, thereby subjecting Himself ( $\mathrm{I}$ speak as a man) to many indignities. He comes to be feasted on, not sacrificed only; as a Peace-offering to apply His own merits, not as a proper Sin-offering, as when on the Cross He merited all for us; and therefore He yields His Body and Blood, i.e. Himself, to be partaken of by us sinners. As partakers of the altar, we are permitted to eat of the sacrifice; which sacrifice in this case is that Man who is the Most IIigh God. 'That, therefore, of which we 
Спар. II. eat, the same we are most humbly to worship; not the less, but the more, because in so giving Himself to us He is stooping so very low for our sakes. The very rule of giving thanls before meals, if we rightly consider it, changes itself into a law of adoration when it is applied to this Meal. If "every creature of Grod is good, and to be received with thanksgiving," how nuch more that Flesh and Blood which the Son has taken into His own Divine Person, and by which He gives Himself to us. If we really believe that that which He declares to be His own Flesh and Blood is Jesus Christ giving Himself to us under the form of Bread and Wine, how can we help thanking, and therefore adoring, (for to thank God is to adore,) the unspeakable Gift, as well as the most bountifnl Giver? seeing that in this case both are one. We may reverently apply here the apostolic words, "For if I by grace be a partaker, why am I evil spoken of for that for which I give thanks ${ }^{\mathrm{y}}$ ?"

$\S 47$. Once more. It is the unquestionable doctrine both of the Old and New Testament, that, without prejudice to the special official priesthood of the sons of Aaron in the one dispensation, and the successors of the Apostles in the other, all the people of God, with the true Melchisedec at their head, are " a kingdom of priests, a royal priesthood," and every one is a "king and priest unto the Father, to offer up spiritual sacrifices, acceptable to God by Jesus Christ." None may doubt that the chief of those spiritual sacrifices is that which causes all the rest to be acceptable,-Christ Himself offered up to the Father by the offering of His Body and Blood in Holy Communion. Accordingly, the Christian people have been instructed from the beginning to take their part in that offering, by the solemn Amen especially, wherewith they have always responded to the Prayer of Consecration. There is hardly any point of our ritual which can be traced more certainly than this to the very apostolic times. Every one will remember S. Paul's saying, "When thou shalt bless with the spirit, how shall he that occupicth the room of the unlearned say Amen at thy giving of thanks, seeing lue understandeth not what thou sayestz?"-words 
which, in a singular way, bear witness both to the share Crap. II. (тómos) which all Christians have in the priesthood of Melchisedec, and to the distinction which nevertheless exists

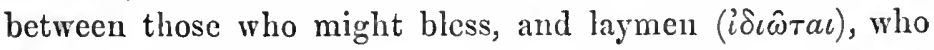
were not permitted to do so. S. Chrysostom's comment on the verse is, "If thou bless in the foreigners' tongue, the ordinary Christian, not knowing what thou sayest, and unable to interpret it, cannot respond the Amen, not hearing 'For' ever and ever,' which is the enda." Justin Martyr mentions the Amen uttered by the people at the end of the consccration as a special circumstance of the Christian Eucharist: "To the Chief of the Brethren is brought Bread, and a cup of Water and Wine; which he taking, sends up (ảvaté $\mu \pi \epsilon \iota)$ praise and glory to the Father of all, by the Name of the Son and the Holy Ghost, and gives thanks at large for these IIis favours vouchsafed unto us. And when he has finished the prayers and the thanksgiving, all the people present, by way of auspicious acclamation, say "Amen'." "And when the Chief Minister has offered the thanksgiving, and all the people have uttered their acclamation, those who are called among us Deacons make the distribution," \&c. Here he secms to mark our common Priesthood by saying that the Celcbrator "transmits" the praycrs and thank-offerings to the Father; and his repeating the mention of the Amen indicates the importance of it.

"What a thing it is," exclaims again Tertullianc, "to pass from the Church of God unto the Church of the Devil! . . to weary with applauding an actor those hands which thou hast just been lifting up unto the Lord! out of the mouth whereby thou hast uttered Amen to the Most Holy Thing, to bear testimony to a gladiator! to say 'For erce' and cver'" (which was another of the Eucharistical acclamations) "to any but our Lord Christ!" And Tertullian, we may notice, was the author of the famous saying, "Nonne et laici sacerdotes sumus?"

How sad to think that so many of those who are called to so high dignity should forfcit or reject it, cither by unworthi-

"On 1 Cor., Hom. 35, t. iii. 477, ed. suvile.

c De Spectaculis, 25.

B Apol. $\$ 61$. 
Cпrap. Ir. ness, or by refusing to own the mysterious Sacrifice which they are called to assist in offering! But those devout communicants who rightly regard themselves as cxercising their share in the Church's Priesthood, will find in this yet another reason for adoring thankfulness to Him who lias so lifted them from the dust, enabling them, with and under Him, by the hands of one especially commissioned to represent Him, to offer to the Father His own Body and Blood.

$\S 48$. But now, to confirm out of Holy Scripture the sacrificial meaning of the words of institution, let us turn first to the Epistle to the Hebrews, which may perlıaps not inaptly be considered, from beginuing to end, as one grand theological harmony, its theme being the pregnant saying, That "the Law hath a shadow of good things to come, but not the very image of the things ${ }^{\mathrm{d}}$." What is the difference between a shadow and an image? Not simply that, both being representations, the one is solid and stationary, the other unsubstantial and fugitive, but this also, which, if I mistake not, is all-important in our present argument; - that the word "shadow" may be used of any thing, which by ever so remote an analogy or faint resemblance calls-a given objeet to the mind; whereas "image" implies a real similitude, an actual eopy more or less exact, of something definitely known to the memory, or bodied forth by the imagination.

And "the very image" (avंìं $\dot{\eta} \epsilon i \kappa(\dot{\nu} \nu)$ adds the idea of perfection as an image,-instructs us that in this case we are to regard it as the authorized aud authentic copy, the most perfect likeness of the thing represented which the material employed could admit of. The phrase seems to answer very nearly to the rell-known philosophical form instanced in

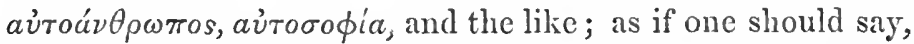
av่roєík $\omega \nu$-as complete an image as in the nature of things, and according to the mind of Him who framed them what they are, could possibly exist.

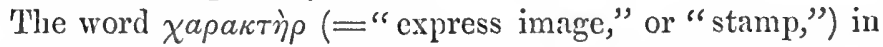
Heb. i. 3, seems to convey the same idea, in reference to the mystery of the revelation of the Father through the Son; as we read, "No man liath seen God at any time: the only-

$$
\text { a Heb. x. } 1 .
$$


begotten Son, which is in the bosom of the Father, He hath CaAr. Ir. declared Him;" the Son, to speak with the Athanasian di-

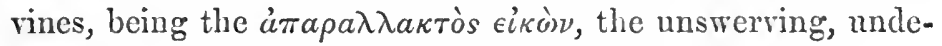
viating, unmodified Image, of the Eternal Father.

Applying this exposition to S. Paul's phrase, we come to sone such result as the following:- that the visible part of the Gospcl system, or at least some portion of it which the Apostle was particularly spcaling of, is not simply the shadow, but the reflection, as perfect as can be, of certain invisible things now existing in the heavenly places, of which the corresponding part of the law was but an "example," $\dot{\pi} \pi 0^{-}$ $\delta \in i \gamma \mu a$, an indication by way of pattern or sample, and in comparison a most imperfect "shadow." In the Gospel you sec the object itself, as in a mirror; the Law could at most present but a rough outline or sketch of it. And the Image in the Gospel is of things eren now in being, only far above out of our sight; whercas the Law was altogether prophetic,

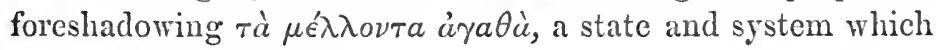
as yet had no existence.

This comparison the Apostle proceeds to apply to the yearly sacrifices of the Law, especially those which took place on the day of atonement. He demonstrates their shadowy and imperfect nature, by the witncss, first of the Law which enacts them, decrecing their annual repetition ${ }^{\mathrm{c}}$; then of the fortieth Psalm, predicting their abolition when IIe should come who should do God's wills; and lastly, of the prophet Jeremiah, announcing that cntire remission which would be inconsistent with the "remembrance of sins made again every year"." And so he passes on to describe "the very Image" which has taken place of these shadows, in words which answer to nothing surely on earth but the holy Sacrament of the Eucharist. We have " boldness to enter into the holiest by the Blood of Jesus, by a new and living way, which He hath consecrated for us, through the veil, that is to say, His flesh; and" we have

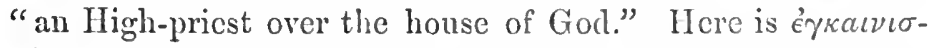
pòs, an opening by solemn dedication of a new way into the holiest, and that by our Lord Ilimself, in virtuc of Itis Blood, and by mcans of His Body, broken and rent, as was
c Heb. x. 2-4.
f Ibid. 5-10.
* Ilid. $15-18$.
4 1lid. 19-25. 
Crap. II. the veil which represented it; and this in His office as Priest, over God's temple. And then comes a distinct account of the preparation, i.e. Baptism with repentance, Faith, and Charity. For, 1. the "heart" must be "sprinkled from an evil conscience, and the body washed witl pure water"; 2. "the profession of our faith" must be "held fast without wavering;" and 3. we must "consider one another, to provoke unto love and to good works."

What is this but the priesthood of the true Melchisedec exercised on carth; as in other parts of the Epistle the exercise of it in heaven is described, either simply (as in the places noted below ${ }^{\mathrm{i}}$, or as identical with one function of the Aaronical priesthood, the entrance of the ligh-priest into the holy of holies? (as in chap. ix. and xiii. 10-16). If the Bread and Wine is not mentioned in words, it is sufficiently implied in these repeated referenees to Melchisedec; and the omission itself is significant, shewing it to be the will of the Holy Ghost that the worshipper should not allow his mind to dwell in the least upon what he sees in this Sacrament. It is strictly to be to him an Image, lifting him up to the great invisible realities even now going on both here and in heaven.

$\S 49$. This view of the Christian saerifice was gathered from the Epistle to the Hebrews by some of the greatest and holiest Father's of the Church, using the liturgical services to which they were accustomed as a commentary on that Epistle. Thus S.Ambrose, taking occasion from a verse in the Psalms ${ }^{k}$ :

"Surely every man walketh in an image. In what image, then, dotl man walk? In that, of course, after the likeness whereof he was made; i.e., after the image of God. Now the image of God is Christ, who is the brightness of His glory, and the express Image of His Person.

"Christ, therefore, the Image of God, came to the world that we might no longer walk in a shadow, but in an image. For every follower of the Gospel walketh in Christ, the Image. . . Therefore, as the people of the Jews went astray, because they walked in the shadow, so the Christian people go

i Heb. iv. $14-$ v. 10 ; vii. $1-3,12-28$; viii. $1-7$.

k On Ps. 38, [39,] v. 6. $\$ 24$. 
not astray, walking as they do in the Image, and having the Crap. II. Sun of Righteousness shining out upon them. O good Image, not coloured with the implements of the painter's art, however brilliant, but wrought out in the fulness of the Godhead!"

"k First, then, the Shadow led the way, the Image hath come after, the Truth has yet to be. The Shadow in the Law, but the Image in the Gospel, the Truth in the heavenly places. The Shadow of the Gospel and of the congrcgation of the Church in the Law; the Image of the Truth to come in the Gospel ; the Truth in the judgment of God. And so, what things are now celebrated in the Church, the shadow of them was in the discourses of the prophets. Their shadow in the deluge, and in the Red Sea, when our fathers were baptized in the cloud and in the sea. Their shadow, in that rock which gushed ont in water, and followed the people. Was not that, in shadow, a sacrament of this holiest mystery? Was not the water from the rock in shadow as it were blood from Christ, in that it followed the people who were hastening away from it, that they might drink and not thirst ; be redeemed, and not perish?

"But now the shade of night and of Jewish darkness hath departed, the day of the Church hath drawn nigh. Now we behold our good things by an image, and we possess the good things of the Image. We have seen the Chief of Priests coming unto us-we have secn and heard Him offering for us His own Blood: we priests follow as we may to offer sacrifice for the people, though weak in clescrts, yet honourable in sacrifice. Because, although now Christ is not secn to offer, neverthcless He is Himsclf offered on earth when Christ's Body is offered; or rather, He is Himself manifested as offering in us, it being His own word which sanctificth the sacrifice which is offered. And while He Himsclf stands by us, our Advocate with the Father, we nevertheless see Him not now: then we shall see Him, when the image shall have passed, and the truth come. Then no longer throngh a glass, but face to face, shall be seen the things that are perfect.

"Go up, then, O man, into hearen, and thou shalt be- 
Cнар. II. hold the things whereof in this world there was the shadow, or the image. Thou shalt behold not in part, not in a dark parable, but in fulfilment; not under a veil, but in the light. Thou shalt behold the true Light, the eternal and perpetual Priest, of whom thou didst here behold the images,-Peter, Paul, John, James, Matthew, Thomas. Thou shalt see the Perfect Man, not now in image, but in truth; for 'as is the heavenly, such are they also that are heavenly."

More briefly again, in the book on the Duties of Christian Ministers" : "Those things then we ought to seek, wherein is perfection, wherein is truth. Here is the Shadow, here the Image, there the Truth. The Shadow in the Law, the Image in the Gospel, the Truth in the heavenly places. Beforetime a lamb was the offering, or a bullock, now Christ is offered; offered, that is, as Man, as capable of suffering: and as Priest He offers Himself, that He may forgive our sins; here in image, there in truth, where with the Father He interferes for us as an Advocate.

"Here then we walk in an image, in an image we behold; there face to face, where full perfection is; because all perfection is in Truth."

S. Chrysostom, expounding the Epistle to the Hebrews, assumes all along the substantial identity of the Eucharistical office with Christ's continual sacrifice in heaven.

"'The priests of old,' saith the Apostle, 'serve to the example and shadow of heavenly things.' What things speaks he here of as heavenly? the things spiritual. For what if they are celebrated on earth? they are nevertheless worthy of heaven. For when our Lord Jesus Christ lies immolated, when the Spirit draweth nigh, when He is here who sitteth on the right hand of the Father, when by the Laver men become His children, when they are denizens of the heavenly places, when we have there our country, our city, and conversation, when we are strangers to things here,how are not all these 'heavenly things?' Yea, let me ask, are not our liymus heavenly? the very strains which the Divine choirs of the incorporeal powers chant on high, do not we also, here below, utter notes in harmony with them? Is not 
our Altar, too, heavenly? Do you ask how? It hath noughit Chap. II. of flesh; the things presented there become altogether spiritual. Not into ashes, not into smoke, not into sacrificial steam is the Sacrifice dissolved, but it renders the Gifts set out there bright and glad to look upon. And how are the offices less than heavenly, sceing that unto the persons ministering unto them are still spoken, from the time that they were first uttered, the words, "Whose sins ye retain, they are retained; whose ye forgive, they are forgiven?' How is it not all heavenly, when these have the very keys of heaven ?"

A few lines on he writes: "See thou do all things according to the pattern which was shewed thee in the Mount. Did he see then as concerning the construction of the Temple only, or concerning the sacrifices and all the rest? Nay, you will not be wrong in affirming this latter as well. For the Church is heavenly, yea, it is nothing else than a heaven "."

Again, comparing the sprinkling of blood, by which the Mosaic corenant was inaugurated, with our Lord's Blood in the holy Eucharist, he writes ${ }^{\circ}$ " Our purification was not bodily, but spiritual, and the Blood spiritual. How? Because it flowed not from any body of an irrational animal, but from a Body formed by the Spirit. With this Blood, not Moses, but Christ sprinkled us, by the word which He spake: 'This is the Blood of the New 'Testament for the remission of sins.' 'This word, instead of hyssop, being dipped in the Blood, sprinkles all. And whereas in that instance the body was cleansed from without, (the purification being bodily,) here, because the cleansing is spiritual, it enters into the soul, and cleauses it; not being simply sprinkled over us, but springing as a fountain in our souls. The initiated know what I mean.

"Again, in the former instance, he used to sprinkle the surface alone; and the person sprinkled would wash himself again; for he did not, of course, go about always stained with blood: but in the soul it is not so; rather the Blood mingles itself with our very being, making it strong and chaste, and training it on to the Unapproachable Beauty itself."

n Hom. xiv. on Ilebrews viii. 5, t. iv. 507, ed. Sav.

- Hom. xvi. on Heb. ix. 22, p. 518.

G 2 
Criap. II. On ch. x. 3, he writes": "God ordained (saith the Apostle) continual offerings, by reason of weakness; and 'a remembrance of sins,' to take place. What then? do not we offer daily? Yes, we offer, but it is by way of memorial of His deatl. And this memorial is one, and not many. How is it one, and not many? Because it was once for all offered, as that one which was brought into the Holy of Holies. .... For it is the same [Person] whom we offer always; not now one [sheep], and to-morrow another, but always the same. And so the Sacrifice is One. .. Christ is One everywhere, being in His fulness both in this place and in that, One Body. As, therefore, though offered in many places, He is but One Body, and not many bodies, so also but One Sacrifice. He is our High-Priest, Who offered the sacrifice which cleanseth us. That same we now also offer, that which was then offered, the Inexhaustible. This is done for a memorial of that which was then done. For, Do this, He saith, in remembrance of Me. We offer not another sacrifice, as the High.Priest then, but the same always. Or rather, we celebrate a memorial of a Sacrifice." Thus far of the Epistle to the Hebrews.

$\S 49$. And there is another book of Holy Scripture, which seems from beginning to end as if the Holy Spirit had indited it partly for this very purpose, that it might impress on Christ's people the greatness of Christ's continual sacrifice, whether on earth in Holy Communion, or in hearen by His appearing as our Advocate. It begins by thanking Christ for having made us kings and priests to Ilis Father ${ }^{q}$. It introduces Him in the first vision as the Son of Man clad in priestly apparel, the long robe and the girdlc; and walking in the midst of golden candlesticks, the well-known furniture of the Temple ${ }^{r}$. It relates to the fulness of the New Testament, such as it was completed at Pentecost; for it is the revelation given to our Lord, as to the Prophet like unto Moses, of things which were "shortly to come to pass ;" it describes Him once and again as "Him that liveth, and was dead, and is alive for evermore ${ }^{s}$ " the Priesthood which it

\footnotetext{
p Hom. xvii. p. $523 . \quad$ q Rey. i. 6. $\quad$ Ibid. 12, 13, "Ibid, i. 18; ii. 8.
} 
delineates is that which $\mathrm{Hle}$ exercises in glory, not that Crap. II. which wrought out its work upon the Cross. He is here the antitype of Melchisedec, not of Aaron; or rather of Aaron within the veil, not in the outer Tabernacle. His descriptions of Himself in the letters to the seven Churches, His promises and threatenings, are frequently associated with that most holy place: as where He says, "To him that overcometh will I give to eat of the hidden mannat," with a probable allusion to the manna laid up by the ark; where He engages to give a "new name," such as "Holiness to the Lord;" or to clothe His faithful ones in white apparel; where He speaks of having "the key of David ;" of setting "an open door" before us; of making him that conquereth "a pillar in the Temple of God ";" and finally, not as Priest, but as King, of granting to such an one to sit on His thronc, as He on His Father's throne.

The second vision, seen through a door opened in heaven $x$, and signifying also at its commencement that it related to things which should fcllow on that opening,-i. e. on the rending of the veil, which is His Flesh,-has its sphere entirely in a place of Divine worship, call it Temple, Tabernacle, or Church, the very sanctuary of the Holy of Holies itself. There appears the mercy-seat, a throne in heaven, and $\mathrm{He}$ that sitteth upon it; and around it the inferior thrones of God's people, twenty-four in number-twelve prophets and twelve apostles-as kings, sitting with crowns of gold on their heads; as priests, clothed in white raiment; lamps and a glassy sea before the throne, and elerubims within and around it. And it is all perpetual worship and thanksgiving; the Evangelists represented by the cherubim sounding the key-note, and the $t$ wenty-four taking it up with the most solemn act of worshipy. Still the IIigh-Priest does not appear, for the mystery as yet is only of Creation; but now, as a sealed book, comes that of Redemption, and One only in heaven and earth is found worthy to open it and loose its seals. Christ, our High-Priest and Sacrifice, is "the end of the Law for righlteousness ;" and how is IIe symbolized? not now

t hev. ii. 17. "Ibid. iii. 5, 7, 8, 12, 21. " " Ilid. iv. $1 . \quad$ y Ibid. $9-11$. 
Cunar. II. as the Priest, but as the Victim; a "Lamb, as it had been slain z," but which now had ascended up on high to receive gifts for men, i. e. the sevenfold gifts of the Holy Spirit, both of power and of wisdom; "the seven horns and seven eyes, which are the seven spirits of God sent forth into all the earth a." Observe where He stands ; "in the midst," or eentral point, before the throne or mercy-sent,-the regular station of the sacrificing Priest before the altar. For as a King, our awful Melehisedec "sitteth on the right hand of God the Father Almighty;" but as a Priest for ever He "standeth on the Mount Sion," in the height of the heavenly Jerusalem, "with His hundred forty and four thousand redeemed from the earth," presenting them by His own merits "without fault before the throne of God;" He standeth as slain: and (mark it well) as slain He is adored. For this is the order of the service. He cometh and taketh the Book of Proplicey (received by Him for men, as all other gifts, of His Father on His Ascension) out of the right hand of Him that sat upon the throne. The mention of the right hand is most commonly a token that merey, as well as power, is being exercised. The receiving, then, of this gift of propliecy by the Mediator as a divine gift to the Church, is the signal for the whole Church to adore specially Him who so receiveth it for them. "The four beasts and fourand-twenty elders fell down before the Lamb." Surely, when the same Divine Being, the Lamb slain, receives for us and gives us His own Flesh and Blood, His own Self, His own Person, to be our very meat and drink, to nourish us to cternal life, less than adoring thankfulness is impossible.

The ritual (so to call it) proceeds with circumstances which kcep up in a remarkable way the notion that the whole is probably an antitype of the Tcmple services, all but those which were strictly penitential or atoning. There is the sacrifice of praise, the thank-offering, for they have each his harp; and of prayer, the peace-offering, for there are the " golden bowls (vials) full of odours, which are the prayers of the saints " ;" aud there is, not the anticipation, but the memory of Christ's denth; for the new song which they sing in answer to the
zRev. v. 6.
${ }^{a}$ [b.d, i. 4.
bIbid. v. 8. 
call of the true David is, "Thou art worthy to take the book, Crap. II. and to open the seals thereof: for Thou wast slain, and hast redecmed us to God by Thy blood out of every kindred, and tongue, and people, and nation; and hast made us unto our God kings and priests: and we shall reign on the earth c." And to correspond with the whole burnt-offering, there is the concluding act of adoration and homage in which the Angels and all creatures join. All these are portions of the Liturgy aceording to the use of every Chureh from the beginning: in our own Communion Office they are strongly marked; every one familiar with it will be able at once to point out in it the Thanksgiving ("Lift up your hearts," \&c.), the Intercession (in the Prayer for the Church Militant), the memory of Christ's death, and the Angels taking part in our services.

Only the penitential and strictly sacramental passages find no counterpart in the heavenly office, being in their very nature remedial, and belonging to this imperfect world. But there is no such reason for us to forego adoration; indeed, if we do, we seem to be turning ourselves out of the blessed company which S. John is describing. For as he heard cvery creature in carth, and under the earth, as well as in heaven, giving glory in its orn way to Him that sat on the throne, in words which all the ancient Liturgies used at the end of their consceration prayer; and the four Evangelists answering $\Lambda \mathrm{men}$, (for they represent the rerbal worship of the Church): so he saw both them and the twenty-four elders (namely, the whole body of Christians) begin their service with the act of falling down and worshipping the Lamb, and end it with the same homage to Him that sitteth upon the throne, i.e., as it may scem, to God the Father Almighty. Refusing to adore with the one would secm much the same kind of thing as refusing to say Amen with the other; a thought which surely no Christian can bear.

As the vision gocs on, it becomes more and more evident that we are in a place of sacrifice - the true Tabernacle or Temple. The erents associated with each seal are localized in this way: the first four are marked by roices from the 
Cusp 1I. four Cherubims respectively; the fifth and seventh by the mention of the golden altar before the tlirone, on which incense is offered with the prayers of all saints by an Angel, from a golden censer, and under which are seen the souls of the martyrs. It has four horns, and from it, as from the central spot in the holy place, having a measure of its own apart from the rest ${ }^{d}$, the voices of prayer go forth; in answer to which come the great turns in God's providence appointed for the due ordering of the Chureh and the world; and from which conversely come the roices of holy resignation and thanksgiving, acknowledging how true and just are His judgments. Under the sixtl seal, the true Israelites having been sealed, the countless multitudes from all lands renew their solemn service to God and the Lamb, this time stand. ing, and not falling prostrate, with palms in their hands, as on the Feast of Tabernacles, and in white robes, like the priests in the Temple; and their blessedness is to be before the throne of God.

Further on, when a great crisis and agony is at hand, the Temple and Altar are to be measured by way of preparing for ite. And in contemplation of a great deliverauce, the twenty-four elders enthroned before God fall on their faces and worship Him with thanksuiving: "And the four-andtwenty elders, which sat before God on their seats, fell upon their faces, and worshipped Godf." When, on the other hand, fearful judgments are coming, the temple of God in heaven is opened, and the ark of the covenant is seeng. The hundred and forty and four thousand who follow the Lamb whithersoever He goeth,-i. e., as it should seem, in counsels of perfection,-they also appear before the throne, the four beasts, and the elders, with a song of their own, which ordinary Christians cannot learn.

From the Temple in hearen goes forth the Angel who is to jutcrcede with the Judge of all the earth, to reap His final harvest, the fields being ready; and likewise two other Angels, arengers; one of them bearing a sharp sickle, the other having power over the fire; and the latter calls on the former to proceed with his vintage, the grapes of the
"Lev. xi. 1.
- Ibid. xi. 1.
${ }^{f}$ Ibid. 16.
g Ibid. 19; xv. 5. 
earth being ripe: in which we may observe how our Lord Cirsp. II. delighteth in merey, for the harvest of them that are saved IIe reaps Himself, but the wrathful vintage $\mathrm{He}$ delegates to His ministers.

The sea of glass mingled with fire ${ }^{\mathrm{h}}$ - thought to symbolize Baptism with water and the Holy Ghost, on which, as on a sure foundation, those Christians stand who are yet fighting victoriously-this also recalls to memory the molten sea, which Solomon placed at the entrance of the Temple. And the use of the present tense, "conquering," not as in our English, "lhaving gotten the victory ;" and their singing, not the "new song," but the song of Moses as well as of the Lamb, - these are pregnant signs of their belonging to the Church Militant, although they are admitted to share in the worship before the throne.

The Angels with the vials or bowls of God's wrath come out of the Temple in priests' apparel, because it is the Church's prayer, "Arenge me of mine adversary," which prevails with God to interfere; and therefore one of the Cherubims or Evangelists, on the part of the Church, supplies them with the stores of "deadly wine" which they are to pour out. In the course of the ensuing plagues there is a voice of grave exultation from the earth, from the Angel of the waters, "Thou art righteous, O Lord," which finds an ccho (so to speak) from another Angel out of the altar in heaven: "Lren so, Lord God Almighty, true and righteous are Thy judgments.". At the pouring out of the last vial there comes "a great voice out of the Temple of heaven, from the throne itself, It is donc." One such word besides, and one ouly, is spoken in the New Testament, "It is finished:" when Ife gave up the Ghost. The approaching end of the Passion (so to call it) of Christ's Mystical Body, is announced by the same Divine ery from the throne, as that of IIis natural Body had been from the Cross.

In the following vision of great Babyloni, the scene of the prophetic survey is changed for a time; the mystery of iniquity, with its workings, is to be deseribed in detail,

\footnotetext{
4 liev. xy. 2.

1 Ibid. xir. 5, 7.

' Ihid. xvii, xviri.
} 
CHAr. II. and we are taken into the midst of it, and are made to see how craftily it is ordered so as to correspond with the mystery of godliness: Babylon being set against Jerusalem; the beast from the abyss against the Lamb; the purple and scarlet against the white apparel; the names of blasphemy against the new Name; her foul adulteries against the marriage of the Lamb; the wine of the wrath of her fornication against the river of the water of life; the brand of spiritual slavery in the forehead and right hand, against the holy and saving sign of the Cross; and most especially the worship of the dragon, and of the beast, his vicegerent, against the worship of God and the Lamb. That is the main point, the one worship contradicting the other. Mark, then, with what significance we are invited as it were to return from this fearful survey of Christendom, become heathen again, (the beast's deadly wound healed,) and the judgments impending on it, to tlie glorious uninterrupted ceremonial of the Temple in heaven, such as it had gone on night and day, from the hour of the High-Priest's ascensionk; the four Cherubim and the twenty-four elders falling down as before and worshipping. Him that liveth for ever and ever; the Mediator giving the signal for praise, and the answer made with Amen and Alleluia. Only as the times on earth grow worse, the joyful commemoration, the marriage of the Lamb, is more and more distinctly announced, and the warning against any worship but that of God, how suitable socver it may appear even to a religious instinct, more and more plainly enforced!.

The final vision of the Apocalypse appears to me (desiring to speak with all reverent doubtfulness) to begin with the beginning of ehapter xx., and to recapitulate the history of the whole dispensation briefy, but more at large in the very termination of it. The thousand years on this hypothesis will denote the whole duration of the Church on earth, during which Satan is comparatively bound; cxcept the little time of his loosing at the end, which will correspond with the want of faith which the Son of Man will find when He cometh. This being taken as a brief slictch of the 
working of Christianity on earth, the next section, ver. 4-6, Cras. II. would seem to tell something of what is going on during the same period in the heavenly Jerusalem; according to the manner of this Divine book. Observe, if it be so, how the vision goes on realizing the idea of a perpetual spiritual sacrifice, in which the souls of Christ's martyrs especially, but with them also the souls of all who have kept themselves unspotted from the world, - not worshipping the beast, nor enslaving themselves to him at all, - are living and reigning with Christ, as so many inferior Melchisedecs, priests at once and kings:-kings, for they sit on thrones, and judgment is given them; and it is twice written of them, they reigned, and they are to reign, with Christ a thousand ycars; priests, for it is written again, "They shall be priests of God and of Christ." If of Christ as well as of God, to be sure they adore Christ as well as God in the spiritual commemorative sacrifices wherein they are permitted to join with Him.

And if those sacrifices, as the ancient Church always believed, are all one with our Eucharist on earth, then part of our ritual, one should think, would be to adore Him also.

And what is the conclusion, the perfect consummation and bliss, toward which these heavenly sacrifices are continually tending? It is a divine feast,-- " the marriage supper of the Lamb,"-the river of the water of life, and the tree of life. You cannot read of it without thinking of what we spiritually receive in Holy Communion, any more than you can read of the services going before it without thinking of what we spiritually offer there. By eating of that which is sacrificed, we become "partakers with the altar" ;" both of the altar of the Cross, and of the intercessory altar before the throne.

\$5. Two more points occur in the Apocalypse, both of them suggestive, as it seems to me, of the substantial identity of the earthly and hearenly saerifices. 'The one, that they are both in a certain sense to come to an cud, at " the time of restitution of all things." With regard to our earthly Eucharist the point is unquestionable; we are to "shew the Iord's death till IIe come." For as Theodorct says", "After I Iis 


\section{Cessation of Sacrifice foreshewn in the Apocalypse.}

Cinar. II. coming, there is no more need of the symbols of His Body, the Body itself being visilble." Or in more faniliar and more beautiful language: "When that which is perfect is come, the use of sacraments shall cease; because the blessed in heavenly glory need not any sacramental remedyo." This all will comprehend, so far as our sacrifices and sacraments have anything of this earth. But Holy Seripture seems to affirm the same in a certain way of that which we suppose Holy Communion to be an image of. Concerning our Lord's kingly office, whereof Melchisedec is a type, although "of His kingdom there is no end," it is nevertheless plainly written, IIe shall in the end "deliver it up to God, even the Father." "The sceptre of that spiritual regiment over us in this present world is at the length to be yielded up into the hands of the Father which gave it; that is to say, the use and exercise thereof shall ccase, there being no longer on earth any militant Church to gorern ;" and the Son as Man shall be simply "subject unto Him that put all things under Him, that God may be all in all." In like manner, it would be no strange thing if His priestly office, wherelyy IIe fulfils the other half of Mclchisedec's character, were declared to be so far at an end, as that the perpetual intercession and memorial Sacrifice for the application of His merits to sinners shall have ccased. And accordingly, in the heavenly Jerusalem, he whose visions had all along seemed to place Him in a temple, with its merey-seat and altar of incense, and all its mysterious furniture, now writes, "I saw no temple therein: for the Lord God Almighty and the Lamb are the Temple of it 9." One is afraid to conjecture; but something of the same kind may possibly be intimated in the saying, "At that day ye shall ask in My name: and I say not unto you, that I will pray the Father for you: for the Father Ilimself loveth you, tecause ye have lored Me, and have believed that I came out from God ";"-in the invitation, "Enter thou into the joy of thy Lord;"-in the promise, "He shall gird Ilimself and come forth and scrve them ;" coupled with the other promise, "His serrants shall

- Thomas à Kempis, iv. 11.

" Rev. xxi. 2... p Ilooker, v. 5.1.

S. Juhn xii. 26,27 . 
serve Him, and they shall see His face." If there be any- Crap. II. thing in these surmises, then the Eucharist and the Commemorative Saerifice have this additional mark of identity, that they come to an end together.

51. The other point worth noticing is the significant way in which "the wrath of the Lamb" is mentioned, corresponding, as it may seem, to the threatenings against unworthy receivers, and especially against such as Judas; in that they turn the Blood of the Sacrifiee and Sacrificial Feast into "the wine of the wrath of God." That wine comes out of "the wine-press" which is "trodden without the citys": and by whom is it trodden? by the Son of Man alone; as both. Isaiah and S. John declare ${ }^{t}$ : whether it be for mercy or for judgment, the sins and sufferings of the whole world are gathered into one lieap, and laid upon Ilis head in Mount Calvary; there He suffered "without the gate;" there is that wine-press which He describes in the parable of the Vineyard, as a necessary part of the mystery of the kingdom of God. The contents of that wine-press, duly taken, are the wine which Wisdom, i. e. the Son of God, hath mingled as part of her Sacrificial Feast" ; they are the "wines on the lees well refined," promised for the banquet which the Lord of Hosts was to make to all people in llis mountain, the Church ${ }^{v}$; they are the water made wine, the best of the creation of God, provided for those called to the marriage supper of the Lamb. But unworthily and irreligiously partaken of, they are "the wine of the wrath of God, which is poured out without mixture into the cup of II is indignation;" they are the wine-cup of the fierceness of God's wrath to be given to the great Babylon, God being put in remembrance of her"; they are "the wine of the wrath of her fornication." Sometimes it is Babylon herself who gives it them: "And there followed another Angel, saying, Babylon is fallen, is fallen, that great city, because she made all nations driuk of the wine of the wrath of her fornication ${ }^{x}$;" "With whom the kings of the earth have committed fornication, and the in-

- Rev. xiv. 20.

- Isa. Ixiii. 3 ; Rev. xix. 15.

u lrov, ix. 5.
Isa. xxv. 6.

1 Ibid. $16-19$.

rlier. xiv. 8. 
Crap. II. habitants of the earth have been made drunk with the wine of her fornication ${ }^{\mathrm{y}}$;" "And the woman was arrayed in purple and searlet colour, and decked with gold and precious stones and pearls, having a golden cup in her hand full of abomination and filthiness of her fornication z." Sometimes, in the old prophets, God Himself gives it by the hand of Babylon : "Babylon hath been a golden cup in the Lord's hand, that made all the earth drunken; the nations have drunken of her wine; therefore the nations are mada;" "For thus saith the Lord God of Israel unto me; Take the wine-cup of this fury at My hand, and cause all the nations, to whom I send thee, to drink it ${ }^{b}$ " "For in the hand of the Lord there is a cup, and the wine is red; it is full of mixture; and He poureth out of the same: but the dregs thereof, all the wicked of the earth shall wring them out, and drink them "." In all instances it is the world, more or less, profanely aping the Church; the Sacraments of the Church turned into sacraments of the Devil: that special horror and sin of profaning Christ's Sacrifice, which is in kind the sin forbidden in the third commandment, is spoken of as committed in the greatest conceivable intensity.

The threatenings, therefore, of the Book of Revelations, as well as its rewards and promises, suppose a sacrificial feast, and the Victim worthily or unworthily received. They represent Blood as given to wicked Christians to drink, which Blood is the Blood of the Son of God crucified afresh by their sins; they are guilty of it, and they receive it to their damnation. This tends, so far, to confirm the idea that the heavenly ritual in the Apocalypse is, in fact, our Eucharistic ritual, and that the adoration there practised is a precedent for adoring in the Eucharist.

On the whole, we should, perhaps, be borne out in affirming, after consideration of what has been alleged both from natural piety and from probable interpretation of Scripture, that the presumption is very strong in favour of such adoration,- - so strong, that unless there can be shewn an express precept to the contrary, a loving and thankful Christian

$$
\begin{aligned}
& \text { y Rev xvii. 2. z Ibid. 4. Jer. li. } 7 . \\
& \text { b Ibid. xxy. } 15 . \quad \text { c Ps. Ixxv. } 8 .
\end{aligned}
$$


would practise it of course; so strong, that such an one might СнAP. II. with confidence apply to this case the first half of the divine canon, "Thou shalt worship the Lord thy God," without fear of inadvertently violating the latter, the negative portion of the same, "Him only shalt thou serve."

\section{CHAPTER III.}

WITNESS OF FATHERS, COUNCILS, LITURGIES, AND

CHURCH TRADITION.

$\S 1$. Bur what says Christian antiquity? for it is here as in respect to the Articles of the Faith, or the Canon of Holy Scripture itself. As we could not admit any thing into the Catholic Creed merely upon its appearing to ourselves, ever so strongly, that it was taught as necessary to salvation in Holy Scripture; as we might not insert any book, chapter, or verse in our copies of God's Holy Word merely upon our own strong persuasion of its being so good and Scriptural that it must have been inspired; so also in respect of the Holy Communion, (as of other main points of evangelical worship,) our own Church instructs us that, "before all other things, this we must be sure of especially, that this Supper be in such wise done and ministered, as our Lord and Saviour did and commanded to be done, as His holy Apostles used it, and the good Fathers in the primitive Church frequented it. For, (as the worthy man S. Ambrose saith,) 'Ile is unworthy of the Lord that otherwise doth celebrate that mystery, than it was delivered by Him; neither can he be devout that otherwise doth presume than it was given by the Author d." ",

If, then, we found a consent of Fathers and Liturgies in prohibiting the worship of Christ's Person, present in the Eucharist by the presence of His Body and Blood, we durst not practise it; our reasoning from Scripture and the counsel of our own heart must give way: and if we found the matter left open, though we might humbly and modestly use

d II omily I. of the Sacrament, fe., near the begiming. 
Chap. III. such worship ourselves, we could not positively judge that it was an error to omit it, much less could we denounce the prohibition of it as touching a vital portion of Christian doctrine, i. e. the doctrinc of the Real Objective Presence of Christ's Body and Blood in that Sacrament. But the casc stands far otherwise: for, first, we have positive historical evidence sufficient to convince any fair mind that in the fourth century Christians did universally adore Christ so present, - such cvidence as cannot be set aside without greatly damaging the witness of antiquity in regard both of the Creed and the Canon of Holy Scripture. Secondly, we have nothing at all to indicate that such worship was a recent innovation, or a partial and unnecessary development; but we have very much in the way of presumptive evidence implying its existence among Christians from the very beginning, although, for a reason to be explained, it is seldom, if ever, directly enjoined in the Liturgies.

$\$ 2$. First, then, for the direct listorical evidence. About the middle of the fourth century, S. Cyril, then presbyter, afterwards Patriarch of Jerusalem, wrote his Catechetical Lectures; in the last of which, instructing the newly confirmed how to behave themselves in receiving Iloly Communion, he says, "After having partaken of the Body of Christ, approach also to the cup of His Blood, not stretching forth thine hands, but bending, and saying, in the way of adoration and religious ceremonial e, Amen; be thou hallowed also by partaking of the Blood of Christ." The word rendered "religious ceremonial" appcars especially to be limited to that kind of worship which acknowledges a peculiar presence of Deity. That and adoration, taken together, seem to

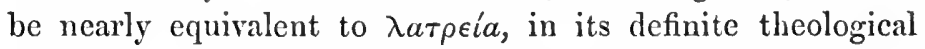
meaning. The posture is evidently not specified, any further than this-that it must be either kneeling, prostration, or standing with a reverent inclination of the body,-venerabiliter curvi, as a later authority expresses it.

The ground of this injunction, the Real Presence, had been repcatedly laid down by $\mathrm{S}$. Cyril before, in words well known, of which I will cite a few ont of many : "Regard not

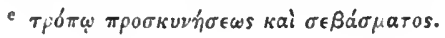


thou the Bread and Wine as merely such, for it is the Body Cuar. III. and Blood of Christ, aecording to our Lord's declaration. And what if thy senses outwardly suggest the other? yet let faith confirm thee; judge not of the matter by thy taste, but by the faith do thou assure thyself, without any manner of doubt, that $\mathrm{He}$ counteth thee worthy of the Body and Blood of Christe." And elsewhere: "Approaching, therefore, come not with thy wrists extended or thy fingers open, but make thy left hand as if a throne for thy right, which is on the eve of receiving the King. And having hallowed thy palm, receive the Body of Christ, saying after it Amen g."

The tradition, then, of the mother Church of Christendom in the middle of the fourth century, was to receive with adoration, just because it is the Borly and Blood of Christ. There are no subtleties, no explanations; the simple word of the Lord is support, exposition, reason, and guidance sufficient. And it does not come at all as a portion of S. Cyril's own teaching, but as a rehearsal of the established custom of the Church of Jerusalem. "Hold fast these traditions unspotted, and keep your-elves free from offence. Sever not yourselves from the Communion; deprive not yourselres, by the pollution of sins, of these holy, spiritual mysteries ${ }^{1,}$." He speaks as earnestly, and almost in the same words, as he had before spoken of the Articles of the faith: "Take heed, therefore, brethren, and hold the traditions which ye are now receiving, and write them on the table of your heart." Then, having rehearsed the Nicene Creed, he goes on: "This keep with godly fear, lest haply any of you, being puffed up, be spoiled by the enemy; lest some heretic pervert any of the things delivered unto you. For as a ereed is laying down the money on the table, which thing we have now done, so God requires of you the account of the deposit. I charge you, saith the Apostle, as before God, Who quickeneth all things, and before Jesus Christ, Who before Pontius Pilate witnessed the good confession, that ye keep this Faith as it hath been delivered without spot, until the appearing of our Lord Jesus Christ. The treasure of life hath now been committed nuto thee, and the Master looks for His deposit at IIis appear-

$$
\text { ' xxii. 6. }
$$


Chap.III. ing i" And it is observable that in both instances he follows the phraseology of S. Paul k, who in one place warns us to meet the approaching Antichrist by standing and holding fast the traditions of the Creed; in another, praises the Corinthians for keeping in all points the "ordinances" (marg., traditions) as he delivered them to them. And it is clear that the "traditions" he refers to relate to the public service in solemn assemblies, and most especially to the Holy Communion. The custom therefore of adoration on that occasion, was not simply enjoined in the Chureh of Jerusalem at that time, but it was enjoined as an old tradition, in the same words in which the Apostle liad urged or recommended the rules which he himself had delivered. Is it too much to say that $\mathrm{S}$. Cyril virtually represents it as being an apostolical tradition? At any rate, the mere fact of its having been then a part of the rubric in so venerable a Church, is a reason why it slould not be hastily condemned as in itself wrong or superstitious.

$\S 3$. About 381, the year of the second Ecumenical Council, S. Ambrose, by desire of the Emperor Gratian, wrote his three books "Of the Holy Spirit," to prove and illustrate, against certain heretics, the Godhead of that Divine Person. In book iii. e. 11, he is dealing with an objection alleged by them from S. John iv. 23, 24. Their argument was, if I rightly comprehend it, as follows: "In the saying, "The true worshippers shall worship the Father in spirit and in truth: for the Father seeketh such to worship Him: God is a Spirit; and they that worship Him must worship Him in spirit and in truth,'-the words 'spirit and truth' signify persons, through whom and in whom the Father willeth to be worshipped." This they take for granted, and go on thus to reason upon it: "That person through whom and in whom another is worshipped is not to be worshipped himself. But the Father is worshipped through and in the Spirit; therefore the Spirit is not to be worshipped."

S. Ambrose ' replies to this, first, what interpreters in general would say, that "spirit," as is rery usual, means a spiritual grace,- the grace of loving derotion in the heart,-as "truth" means a deep couviction of the reality of the un-
i v. $12,13$.
k 2 Thess. ii. $15 ; 1$ Cor. xi. 2.
${ }^{1} \S 70$. 
approachable Godhead. (So S. Ambrose here takes it; but, Crus. III. according to the ordinary use of the word 'truth' in S. John's Gospel, it would rather seem to mean the substance of the kingdom of heaven, as opposed to the shadows of the world and of the Law.)

But, secondly, granting that the words in question do really mean the Persons of the Spirit and of Christ, then "God is adored in the Truth, just as He is adored in the Spirit. Either, then, the two are alike inferior,-which God forbid thou shouldst believe,--and so not even the Son is adored; or (which is the truth) the unity of the one is just like that of the other; and then the Spirit also is to be adored ${ }^{\mathrm{m}}$." "Therefore," he repeats, "if in this place they understand truth according to the usual sense, let them understand spirit to be spiritual grace, and there is no offence; or if they explain the Truth to be Christ, let them say that He must not be worshipped.--But then," he goes on, "they are refuted by the doings of religious men, by the whole course of the Scriptures. Thus Mary adored Christ, and is therefore ordained the first messenger of the resurrection to the Apostles, undoing the hereditary bond, and the grievous fault of woman. kind. For so the Lord wrought in a mystery; that where sin had abounded, grace might much more abound. And with reason is a woman commissioned unto men; that she who had been first to be a messenger of sin to the man, might be the first messenger of grace.

"The Apostles, too, adored; and even because they bore the witness of the faith, they retained the office of being masters in the faith. The Angels, too, adored,- - of whom it was written, And let all Ilis angels adore Ilim.

"And they adore not only His Godhead, but also His Footstool, as it is written n, And adore His Footstool, for it is holy. Else, if they deny that in Christ the mysteries of Incarnation also are to be adored, wherein we discern (so to speak) express traces of Divinity, and the ways of the heavenly Word; let them read how the very Apostles adored Him rising in the glory of His flesh.

"Therefore, if it is no disparagement to Christ, that God is m $\$ 72$. Ps. xcix. (xcriii.) 5. 
Chap. III. adored in Christ, because Christ too is adored; neither is it, of course, any disparagement to the Spirit, that God is adored in the Spirit. ...

"But let us consider how the prophet's saying, Adore His footstool, bears upon the mystery of our Lord's Incarnation. For we must not interpret the word 'footstool' by the custom of men, since God is neither corporeal nor finite, that we should imagine a stool placed for the support of His feet. Neither do we read of anything to be adored, save God; because it is written, Thou shalt worship the Lord thy God, and IIim only shalt thou serve. How then should the prophet give a rule contrary to the Law, nurtured as he was in the Law, and instructed in the Law? 'l'he inquiry, then, is no ordinary one, and we must very accurately consider what 'footstool' means. For elsewhere we read, 'Heaven is $\mathbf{M y}$ throne, and earth is My footstool.' Well, but neither may we adore the earth, because it is one of God's creatures.

"But let us see; perhaps the prophet means that that earth is to be adored which the Lord Jesus took on Him in assuming flesh. And so by the footstool the earth is understood, and by the earth the Flesh of Christ, which, to this day, we adore in the Mysteries, and which the Apostles, as we said above, did adore in the Lord Jesus. For Christ is not divided, but One; neither, when He is adored as the Son of God, is it denied that He was born of a Virgin. The Sacrament, then, of the Incarnation being adorable, and the Incarnation the work of the Spirit, as it is written, The Holy Ghost shall come upon thee, and the power of the Highest shall overshadow thee, and the Holy Thing which shall be born of thee shall be called the Son of God,-doubtless the Holy Spirit also is to be adored, since He is adored who, as to His Flesh, is born of the Holy Ghost.

"And to prevent any one's extending this to the Virgin Mary, Mary was the temple of God, not the God of the temple. And therefore He only was to be adored who was performing His work in the temple.

"You see that God's being adored in the Spirit is no ground of objection, since the Spirit also is adored."

This long passage of S. Ambrose is here cited, not only 
on account of the express and inevitable testimony which he CнАP. III. bears to the custom of the Church in his time,-_" "The carth" (which we are bidden to adore) "means the Flesh of Christ, which to this day we adore in the Mysteries ;"-but also because that great theologian and confessor so clearly sets out the principle and reason of such worship, according to the analogy of the faith. The Body present in the Eucharist is to be adored on the same ground which made it right for S. Mary Magdalen and the Apostles to adore our risen Lord; and it follows, from the unity of His Person, that to refuse It adoration is to act as if Christ were divided, and not One; and he signifies incidentally, but not less clearly, that all things and all creatures which are merely adjuncts of His Person, not essential parts of His humanity, (as IIis Soul and Body both are,) - such things, how high and precious soever, are not to be adored; no, not if they come inconceivably near to Himself. The two short sentences relating to the Virgin Mary bring out this eaution very forcibly.

$\S 4$. Moreover S. Ambrose's testimony is distinctly repeated by his spiritual son, S. Augustine. He, in his popular exposition of the 99th Psalm, delivered in Africa about thirty years later than what has been quoted from S. Ambrose,-i. e. about 414-15,-adopts S. Ambrose's interpretation; or rather appeals to it without all question as to the interpretation of the Church.

"Worship His footstool". Sce, brethren, what He commandeth us to worship. In another passage of the Scriptures it is said, The heaven is My throne, and the earth is My footstool. Doth He then bid us worship the earth, since in another passage it is said that it is God's footstool? How then shall we worship the earth, when the Scripture saith openly, Thou shalt worship the Lord thy God? Yet here it saith, Fall down before IIis footstool; and explaining to us what His footstool is, it saith, The earth is My footstool. I am in doubt; I fear to worship the earth, lest He who made the heaven and the carth eondenm me; again, I fear to refrain from worshipping the footstool of my Lord, because the Psalm biddeth me fall down before His footstool. I ask, what is His foot-

- P's. xcix. [xcriii.] 5. 
Chap. III. stool? and the Seripture telleth me, The earth is My footstool. In hesitation I turn unto Christ, since I am hercin sceking Ifimself; and I discover how the eartl may be worshipped without impiety,--how His footstool may be worshipped without impiety. For He took upon Him earth from eartl ; because flesh is from earth, and He reccived flesh from the flesh of Mary. And because He walked here in very Flesh, and gave that very Flesh to us to eat for our salvation,- and no one eateth that Flesh unless he hath first worshipped,-we have found out in what sense such a footstool of our Lord may be worshipped; and not only that we sin not in worshipping it, but that we sin in not worshipping.

"But doth the flesh give life? Our Lord Himself, even when He was speaking in praise of this same Earth, said, It is the Spirit that quickeneth, the flesh profiteth nothing. Therefore when thou bowest thyself down prostrate before the ' earth,' look not as if unto earth, but unto tliat holy One whose footstool it is that thou dost worship; for thou dost worship it on His account: wherefore He hath added here also, Fall down before His footstool, for He is holy. Who is holy? He in whose honour thou dost worship His footstool. And when thou worshippest Him, see that thou do not in thy thought remain in the flesh, and fail to be quickened by the Spirit; for He saith, It is the Spirit that quickeneth, the flesh profiteth nothing. But when our Lord praised it, He was speaking of His own Flesh, and He had said, Except a man eat My Flesh, he shall have no life in him. Some disciples of His, about seventy, were offended, and said, This is an hard saying; who can hear it? And they went baek, and walked no more with Him. It seemed unto them hard that He said, Except ye eat the Flesh of the Son of Man, ye have no life in you: they received it foolishly; they thought of it carnally, and imagined that the Lord would cut off parts from His Body and give unto them; and they said, This is a hard saying. It was they who were hard, not the saying; for unless they had been hard, and not meek, they wonld have said unto themselves, He saith not this without reason, but there must be some latent mystery herein. They would have remained with Him, softened, not hard; and would have learnt that 
from Him, which they who remained, when the others de- Crap. III. parted, learnt. For when twelve disciples had remained with Him, on the others' departure, they, as if in grief for the death of the former, pointed out to Him, how the other were offended by His words, and turned back. But He instructcd them, and saith unto them, It is the Spirit that quickeneth, but the flesh profiteth nothing: the words that $I$ have spoken unto you, they are spirit and they are life. Understand spiritually what $I$ have said : ye are not to eat this Body which ye see; not to drink that Blood which they who will crucify Me shall pour forth. I have commended unto you a certain mystery; spiritually understood, it will quicken. Although it is needful that this be visibly celebrated, yet it must be spiritually understood. O magnify the Lord our God, and fall down before His Footstool, for He is holy."

In this passage I would remark the same three things which were observable in S. Ambrose; the fact, the doctrinal aspect of it, and the caution against abuse. The fact, in His saying, "No man eateth that Flesh unless he hath first worshipped ;" the doctrinal aspect of it, in that it is an acknowledgment, first of the Incarnation, and then of the Real Presence. "Of the flesh of Mary He took Flesh, and in that very Flesh walked here among us." Again: "that very Flesh He gave us to be caten for our salvation." Thirdly, there is the caution against low and carnal understanding drawn from our Lord's saying, "It is the Spirit that quickeneth; the flesh profiteth nothing." Though it is "Ipsa Caro" which we are commanded to adore, it is not "Hoc Corpus quod videtis ;" the very Body, but not subject to the senses. I would observe, also, that ncither of these great teachers in any degree grounds the practice of adoration upon the verse on which they are commenting, but taking the practice for a thing approved and granted, they allege it, both of them, as pointing out the true meaning of that verse; and S. Ambrose, in particular, as strengthening the proof that the IIoly Spirit is to be worshipped; which proposition lie was then maintaining against the Arians or Maccdonians.

$\S 5$. It may be well to add a few words on the ancicut rendering of the rerse in question. As far as 1 have been able to 


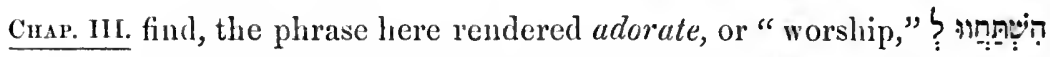
is in every place but three unquestionably followed by a noun denoting the olject of worship. When the place or other adjunct is to be mentioned, the preposition used is or the like-as Psalm v. 7 ; exxxviii. 2; Is. 1x. 14. The three places which might seem exceptional, as to the use of the particle? with the verb of worship, are Ps. exxxii. 7 ; this of which we are speaking, xcix. 5 ; and the last verse of the same Psalm. The two former in the Hebrew are one:

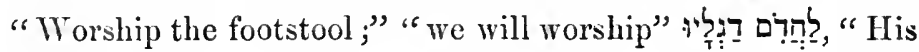
footstool."

There remains the last verse of Ps. xcix., where the Hebrew verb and preposition are the same, only the noun following, instead of "His footstool," is "His holy hill." Now in 1 Chron. xxviii. 2, David speaks of building a house of rest "for the ark of the covenant of the Lord, and for the footstool of our God;" and in Lam. ii. 1, "He remembered not IIis footstool in the day of His anger." Here we see the Temple, or the most holy part of it, represented as the Lord's footstool, in allusion, no doubt, to the Cherubim appearing over the mercy-seat, and the Lord enthroned in His glory between them. But His 'lemple, He Himself tells us, is the type of His Body,--both of His natural Body, and of His mystical Body the Church; and concerning this latter He says in Isaiah lx. 13, "I will make the place of My fect," i. e. My footstool, "glorious."

Again, the holy mountain itself, as S. Augustine remarks on this verse, is a signal type of Christ, as well as of the Church :-_"What is His mountain? we read elsewhere of this mountain, that it was 'a stone cut out of a mountain without hands, which brake in pieces all the kingdoms of the earth, and grew, and became a great mountain, and filled the whole earthp.' What is the mountain whence the stone was eut out without hands? The kingdom of the Jews in the first place, because they worshipped one God. Out of it was hewn a stone-our Lord Jesus Christ. What is 'cut out without hands?' born of the nation of the Jews, without agency of man. That stone grew, and in its growth brake 
to pieces all the kingdoms of the earth, and it hath become Cнар. III. a great mountain, and filled the whole earth. This is the Catholic Church; and do ye rejoice that ye are in communion with it!"

If, then, according to that identity of Christ and His Church which in some sense is continually affirmed in Holy Scripture, we suppose "His holy hill" in the last verse of Psalm xcix. to be equivalent to "Iris footstool" in ver. 5, the precepts in the two, spiritually taken, come to the same thing - a command to adore the Son of God in His holy humanity; and then most especially, when His Humanity is not only most signally manifested, but also mysteriously communicated to us; where the natural Body and mystical Body are made more entirely one than on any other occasion here on earth.

$\S 6$. It is obvious, however, that our appeal to these Fathers does in no degree involve the correctness either of the Septuagint and Vulgate rendering, "Adore Ilis footstool," or of the patristical interpretation of it. Neither the fact of universal adoration, nor the connection of it with the substance of the faitl, depends at all for its evidence on that verse itself. The translation may be ever so incorrect, and the mystical meaning alleged ever so fanciful, and yet the passages will be available to demonstrate, beyond the shadow of doubt, that our Lord's Body was then universally adored in the Eucharist. There is no getting rid of such sayings as "Caro Christi, quam hodieque in mysteriis adoramus ;" "Nemo illam carnem manducat, nisi prius adoraverit." If they are genuine-which no one disputes-they prove the fact: at least, as concerns the Churches of Italy and Africa, i.e. the whole West. For we cannot conceive S. Ambrose or S. Augustine, the one in a publie homily, the other in a controversial treatise written by an emperor's desire against a great and influential party, affirming what any one might lnow by the witness of his own eyes to be false. If their evidence is not to be accepted herc, neitlicr need it in the matter of infunt baptism, nor of the canon of Scripture, nor of any other of the many ecclesiastical usages which they mention, and of which every one of their Chris- 
Crip. III. tian contemporaries must have been just as cognizant as themselves. In short, the matter is too plain to bear arguing upon.

Nor ought it to be unobserved that S. Ambrose in particular implies the practice of adoration to be not only general in his time, but to have come down from the beginning. He does not say "hodie," but "hodieque ;" not "now-a-days," but "to this day." The word is constantly so employed, of things done now as of old, circumstances and usages recalling old times, indications of uninterrupted tradition ${ }^{\mathrm{T}}$.

$\S 7$. There is another well-known passage of S. Augustine, in his letter to Honoratus on the Grace of the New Testament $^{r}$, in which he expounds the 22nd Psalm from beginning to end. When he comes to verse 30 ,-one of his objects being to point out how that the grace of the New Testament stood not in temporal, but in eternal promises,he proceeds as follows:- " 'All they that are rich upon earth have eaten and worshipped;' by 'the rich upon earth' we are to understand the proud, if we were right before in understanding 'the poor' to mean the humble.... For not without significance is the distinction made between them, in that having said before of the poor, They shall eat and be satisfied, here, on the contrary, All the rich of the earth have eaten and worshipped. For they, too, are brought to the Table of Christ, and receive of His Body and Blood; but they worship only,-they are not also satisfied, because they do not imitate Him. For although they feed on Him that is poor, they disdain to be poor. For Christ indeed suffered for us, leaving us an example that we should follow His steps; but in that He humbled Himself, and became obedient unto

q Thus the Dial. de Oratoribus in the works of Taeitus, c. 34: "Crassus, Cæsar, Pollio, ... in early youth dealt with their respective adversaries in those speeches, "quas hodieque cum admiratione legimus." Cicero, in hislast Oration against Verres, § 25 : " dieque (" to this day") ommes sic habent persuasum;"-he is speaking of a transaction which had ocenrred long before. Tiv. i.17: "Hodieque in legilus magistratibusque rogandis itsurpatur idem jus, vi adempta." Velleins, i. 4 : "Vires autem veteres earum urbium hodieque magnitudo ostentat mœnium." As in each of these phrases both are distinetly expressed, the old object or state of things, and the existing fragment or result of it,-so in the pas. sage under consideration: "the same Flesh which the Apostles adored in the Lord Jesus Christ, we, hodieque, 'down to this day,' adcre in the Sacrament."

× Ep. xl. § 66, 67 . 
death, even the death of the eross, the rich scorn Him, and Crap. III. refuse to suffer the like... But since God hath raised Him from the dead, and given Him the Name which is above every name, ... they too, moved by the glory of His Name in the universal Church, come to the table, eat and adore; but they are not satisfied, because they do not lunger and thirst after righteousness; for such shall be filled..... By preaching the world has been moved, so that all the ends of the earth remember themselves and turn unto the Lord, and all the families of the nations worship before Him.... By this enlargement of the Church eren the prond, i. e. the rich of the earth, are brought nigh, to eat; and though not satisfied, yet they adore."

Here it is much to our purpose to remark how the writer again and again mentions the adoration of all communicants as a matter of course, and unirersally known; and also as being a signal accomplishment of a prophecy; the very terms of which prophecy make it co-extensive with the whole Church.

\$ 8. In the East we have, about the mildle of the fifth century, the testimony of Theodorct, pnblisher, as is supposed, a few years before the Council of Chalcedon, principally to counteract the heresy then arising, which denied the continuance of Christ's human naturc. The passage is well known, being constantly and nnanswerably cited as a testimony against the dogma of Transubstantiation, and for that of the Real Objective Presence.

The herctic alleges, that as, by consent of Christians, "the symbols of the Lord's Body and Blood are one thing before the priest's invocation, but after it are changed and become another, so the Lord's Body since His Ascension is changed into the Substance of the Deitys." The reply is, "Nay; for it is untrue that after consecration the mystical symbols depart out of their proper nature; remaining as they do in their former substance, and figure, and form, and being visible and tangible, just as they were $b$ (fore. But the inward sense pereeires them as being simply what they have become, and so they are the object of faith, and are adored,

s Eranistes, Dial. ii. t. iv. 126, ed. Schulze. 
Crap. III. as being those very things which they are believed to be. Compare, accordingly, the image with its archetype, and thou wilt see the resemblance. For the type must needs resemble the reality. And thus that Body, while it hath its former aspect, figure, and outline, and, in one word, its substance as a Body, hath nevertheless, since the resurrec. tion, become immortal and incorruptible. It is deemed worthy to sit on the right hand, and $i s$ adored by the whole creation, as being divinely named the Body of the Lord of nature."

Heretics, it appears, professed to join with the orthodox in every point of this doctrine of the Eucharist. It was taken as an irrefragable, undeniable ground, from which to set out in reasoning on other mysteries. And in respect of the adoration in particular, the worship of Christ's Body by all Christians in the Eucharist is studiously set down as the correlative of the worship of the same Body by all created beings in heaven. And the Church's seal was in a manner set to this doctrine, at least by implication. For had there been any thing at that time supposed heretical in it, there was no lack either of subtle and bitter opponents to expose, or of sound and watchful theologians, like S. Leo, to correct the error: as the most cursory glance at that page of Church history will shew, in which Theodoret's name is one of the most conspicuous, more by the restlessness of his accusers than by any special doings of his own. In fact, it is well known that he was both upholden by $\mathrm{S}$. Leo, and in the Council of Chalcedon restored to his see by acclamation on saying anathema to Nestorius; in whose heresy he had never sympathized, although from his good opinion of the man, he had been long unable to believe that he meant so much ill, and had shrunk from proceedings which he feared might countenance the opposite error. But let Theodoret have been what he may, the fact that, at such a time, those very public statements of his remained uncensured and uncontradicted, is an additional warrant for our believing that on the Eucharist, at any rate, he did but express the known mind and practice of the holy Church throughout the world. 
$\S 9$. Three centuries after Theodoret's time, in the course Crap. III. of the controversy on image-worship, we find each several section of the Church bearing its testimony-incidental indeed, but not the less trustworthy-to the doctrine of the Real Presence, and the consequent practice of worshipping Him who vouchsafes to be so marvellously present. The partics or sections alluded to are three: the Iconoclasts, who, as is well known, condemned not only the adoration of images and pictures, but all religious use of them ; the Imageworshippers, who enforced that adoration under anathema; and a third party, more moderate and apparently more orthodox than either, who justified the use of images as a means of edification, but protested against adoring them. Each had its regular authentical cxpression in a formal synod: the Inconoclasts at Constantinople, A.D. 754, under the Empcror Constantine Copronymus; the Iconolatræ (so to call them) at Nicrea, in 787 , under the patronage of Irene and Constantine her son; and the moderate, or, as it may be called, the Gallican, at Frankfort, in the palace of Charlemagne, in 794. It is obvious that in the course of their discussions the question of Eucharistical Adoration was almost sure incidentally to arise; since that practice also, in one aspect of it, might seem to sanction the worship of sanctified creatures.

Accordingly, we find the Iconoclasts arguing on it as follows:-Having laid down as a principle in a former paragraph, "Where the Sonl of Christ is, there also is His God. head; and where the Body of Christ is, there also no less is His Godhead t;" (which saying was allowed by their opponents as a great truth, and the use they proposed to make of it alone disavowed;) they proceed to apply it to the Sacrament of Holy Communion.

"Let them be glad and rejoice, and speak out with all confidence, who frame, and yearn after, and venerate the true Image of Christ with an uncorrupt soul, and who offer it for salvation of soul and body; - which Image our Priest and God (having unreservedly taken to Himself, of us, the lump out of which we are kneaded) did in IIis own Person

\footnotetext{
' Harduin, Conc. iv. 36+ C.
} 
Crap. III. deliver to His initiated, at the time of His voluntary Passion, for a most evident type and memorial. For being about to yield Himself, of Ifis own accord, to His memorable and life-giving death, He took the Bread and blessed it, and gave thanks and brake it, and distributing it said, 'Take ye, cat, for remission of sins: this is My Body.' Likewise also distributing the Cup He said, "This is My Blood: this do in remembrance of Me :' as though no other kind or form were selected by Him in the Church under heaven, which should be capable of imaging forth His Incarnation. Behold, then, the Image of His life-giving Body, so richly contrived, and endowed with all honour. For what did the All-wise God devise herein? Even to shew and unfold evidently to us men the mystery wrought out in the dispensation concerning Himself: that even as that which He took of us is simply matter of human substance altogether perfect, not having the lines of a distinct person with independent existence, no additional person thrown as it were into the Divinity; so also He enjoined His Image to be offered in that matter which He selected, even the substance of bread, -not representing the form of a man, lest jdolatry creep in unawares.

"Wherefore, as Christ's natural Body is holy, having been taken into God", so plainly is His adopted Body also-that is, His holy Image, as being by grace taken into Grod through a certain sanctification. 'This, as we said, was the purpose of our Lord Christ: that as He deified the Flesh which He took, from that very union, with the sanctification which was His own by nature, so also the Bread of the Eucharist, being sanctified as a true Image of His natural Flesh by the coming of the Holy Ghost, He willed to become a Divine Body, not without the instrumentality of the Priest, who maketh the offering by transference from that which is common to that which is holy.

"Once more, that natural Flesh of our Lord, animate and gifted with reason, was anointed in respect of His Godhead with the Holy Ghost. So also the divinely ordained Image of His Flesh, the Divine Bread, was filled witl the Holy 
Ghost, together with the Chalice of the life-giving Blood Crap. III. from His side. This then is revealed as the true Image of the dispensation of Christ our God coming in the flesh, as was aforesaid; thus the true Framer and Quiekener of our nature delivered it unto ns with His own lips ${ }^{r .}$."

Without assenting to all their statements and reasonings, thus much one may gather from them in corroboration of what has been said: that with S. Ambrose they applied the expression of S. Paul x, "The very Image of the 'Things," to the holy Eucharisty; that they regarded the Bread after consecration as not the natural Body of Christ, but yet most truly His Body by some special dispensation ${ }^{z}$; that they worshipped that Body in, or with, or under the Bread, because of the Godhead with which it is inseparably united ${ }^{a}$; that they could not worship the Breal, as sueh,-_it would be mere idolatry,-and therefore Christ would not have His memorial formed into a likeness of Him; and that they eonsidered all this as connected with the doctrine of the Incarnation in such sense, that worshipping Christ's Humanity under any other image, would cause confusion in that doctrine. Observe that these were the "Protestants" of the timewatching, as they thought, with a godly jealousy against everything that might look like exaggerated respect to the creature: yet how far do they go in enforeing the adoration which many good men now religiously shrink from!

v Harduin, Conc. iv. 368, 9.

$\times$ Heb. x. 1 .

$\checkmark$ Calling it $\tau \dot{\gamma} \nu \dot{\alpha} \lambda \eta \theta \hat{\eta} \tau o \hat{v} \mathrm{X} \rho \sigma \sigma \tau o \hat{v}$

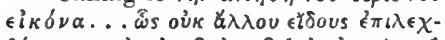

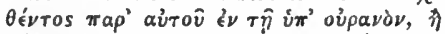

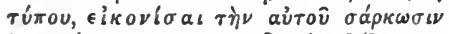

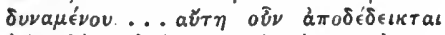

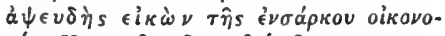
$\mu l a s$ X

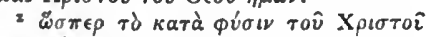

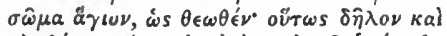

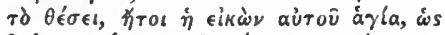

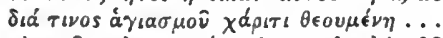

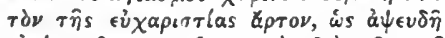

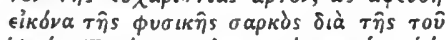

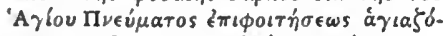
$\mu \in \nu O \nu, \theta \in \hat{\imath} O \nu \sigma \hat{\omega} \mu \alpha \in \dot{v} \delta \delta \kappa \eta \sigma \in \gamma^{\prime}(\nu \in \sigma \theta \alpha u$.

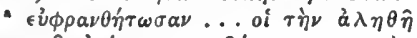

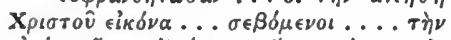

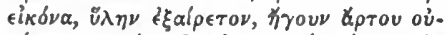

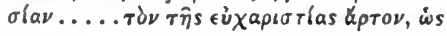

$\grave{\alpha} \psi \in v \delta \hat{\eta} \epsilon \hat{i} \kappa \delta \alpha a \tau \hat{\eta} s \phi v \sigma \iota \kappa \hat{\eta} s \sigma \alpha \rho \kappa \delta s$. Connect these sayings with the principle which they had previously liud

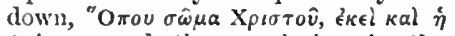
$\theta \in \delta$ rns, - and the conclusion in the text, I think, can hardly be aroided.

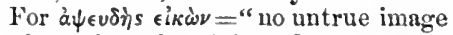
of a tbing absent:" and to venerate the Sacramental Bread as an image of Christ's present Body, is to all but Nestorians a mode of worshipping Christ's Body through or under that image. Indeed, the very gist of the controversy seems to have been this - whether it was lawful to worship inages with a worship passing through the innage (so to spenk) to the reality; it being allowed that such worship might be paid to the holy Eucharistic symbols. 
CHAP. III. The opposite party, which proved the dominant one, objected to the term Image as unscriptural in its application to the Eucharist; in which, however, they were incorrect, if $\mathrm{S}$. Ambrose is right in his interpretation of Hebrews $\mathrm{x}$.

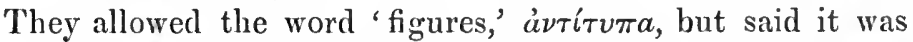
only applied before consecration, - a most erroneous statement, corrected in the margin by the editors of the Councils, both Roman and Greek; from S. Cyril of Jerusalem, S. Gregory Nazianzen and others ${ }^{b}$. But these very mistakes being made in their eagerness to glorify the Sacrament as much as they could, it is needless to seek testimonics in favour of adoring the Inward Part of it from them.

The Council of Frankfort, as is notorious, was very plain and express in its condemnation of image-worship. Their second canon is, "The question was mooted of the recent synod of the Greeks, holden at Constantinople, touching the worship of images; wherein it was set down, that such as would not pay service or worship to the images of the saints, as to the holy Trinity, should incur an anathema. Our holy Fathers above mentioned rejected altogether such adoration and service, and that with scorn, and unanimously condemned itc." And one of their reasons for rejecting it, alleged afterwards to Pope Adrian, was,-"It is great rashness and extreme absurdity to be minded to put the said images on a par with the Body and Blood of our Lord d." Herein they adopt the argument of the Iconoclasts, whose decisions they had before them, embodied in those of Nicra; and shew that they regarded it as a matter of course to adore Christ's Body and Blood in the Eucliarist, since otherwise the adoring of images would be no real intrusion on the rights of that Sacrament.

$\S 10$. Thus we seem to have evidence sufficient that down to the beginning of the ninth century, i. e. through all the ages of comparatively unbroken unity in the Church, the Body and Blood of the Man Christ Jesus-of Him who is God and Man-was adored as present after consecration in the Eucharist; i. c. Christ Himself was adored, as present by the Presence of His Body and Blood. Neither the de-
b Harduin, iv. $372 \mathrm{~A}$.
c Ibid. iv. 904. D.
¿ Ibid. $791 . \mathrm{D}$. 
pravers of the faith on the one hand, nor the maintainers of CнAт. III. purity of worslip on the other, ever seem to have found any difficulty in that point. Who can help concluding that it came down direct from the Apostles? especially considering what I will venture to call the strong presumption made out in farour of it from Holy Scripture and natural piety. It will have been seen that both S. Ambrose and S. Augustine use expressions and arguments which would be quite unwarrantable, unless they knew the practice to be a real apostolical tradition. S. Ambrose's "hodieque," and S. Augustine's "Nemo manducat, nisi qui prius adoraverit," would be neither of them honest sayings, were they not uttered under that conviction. And their arguments, grounded as they are on the two great and simple verities of the Incarnation and the Real Presence, are of course good for all times as well as for their own.

Besides, it is hard to imagine how such a serious and awful innovation could lave made its way into the most solemn and at the same time the most frequently repeated of all Church ordinances, without some notice or discussion at the time. Other questionable tenets and usages, such as purgatory, the worship of the Virgin, and of saints and images, and the papal supremacy, may be traced in Cliurch history, coming on by degrees, and some of them not without much noisy discussion and conflict: in regard of eaeh one of them a time may be certainly assigned, when it was no part of the necessary teaching of the Church. Not so in respect of this rite of Eucharistical Adoration. There is nothing in early Church history or theology, any more than in Holy Scripture or in the creeds of the Church, to prevent our receiving in their full cxtent the statements of the fourth century concerning it. It is a casc coming naturally and completely under S. Augustine's famous aphorism, "that whatsocver positive order the whole Church everywhere doth observe, the same it must needs have received from the very Apostles themselves, unless perhaps some general council were the authors of it e."

$\$ 11$. The only plausible objection, that I know of, to the

- Ilooker, Eccl. Pol. viii. 5. 3, quoting S. Aug. Ep. 108, c. 1. 
Cnap. III. foregoing statement, arises from the omission of the subject in the primitive Liturgies, which are almost or altogether silent as to any worship of Clnist's Body and Blood after consecration. We find in them neither any form of prayer addressed in special to His holy Ilumanity so present, nor any rubric enjoining adoration inward or outward.

But with regard to the first, the omission of special collects to our Lord, that it does not negative adoration is demonstrated at once by the twenty-third canon of the 'Third Council of Carthage, A. D. $397^{\mathrm{f}}$; at which council S. Augustine was present: and his express testimony to the universal custom of adoration has been here quoted at large. Yet lie was a party to the following enactment: "Ut nemo in precibus vel Patrem pro Filio, vel Filium pro Patre nominet. Et cum altari assistitur, semper ad Patrem dirigatur oratio. Et quicunque sibi preces aliunde describit, non eis utatur, nisi prius eas cum instructioribus fratribus contulerit." A rule remarkable on many accounts :

First, as a striking illustration of the great liberty allowed for variation of Liturgies in the several dioceses, or even in the several congregations; since it implies, apparently, that cvery Bishop and Priest might adopt prayers from any quarter, taking good advice upon them. So much the more remarkable is the concurrence of all the Liturgies in so many material points.

Secondly, we see what danger there was under such circumstances of ill-advised language, unawares countenancing the very gravest of doctrinal errors; such as confounding the Persons of the Trinity one with another, naming the Son for the Father, and the Father for the Son.

And thirdly, (which is much to our present purpose,) there is a direct prohibition, for whatever reason, of special vocal prayer to our Lord, as also to the Iloly Ghost, in the Communion Office. How is this to be accounted for? Perhaps by recollecting that the rationale of the Holy Eucharist is to be a sacrifice offered by the Son to the Father; it is the transference for the time to earth of the great perpetual commemorative sacrifice in heaven; and there might be

\& IIarduin, i. 963. 
danger of devout persons not considering this, and obscuring Сиар. III. the simplicity of the priestly act by intermingling prayers to our Lord with those which are eminently and particularly offered by our Lord; He, our Melchisedec, being the true Consecrator, as well as the true Baptizer.

It might seem as though this African rule were far from being invariably observed,-for in the Roman Canon itself, as Bishop Andrewes remarksg, there are four collects addressed to our Lord; and among the normal liturgies of the East, that of S. James has four ${ }^{\mathrm{h}}$, S. Chrysostom three, S. Mark two onlyk; the Persian family, as represented, according to Mr. Neale, by the Liturgy of Theodore the Interpreter, as many'. In the Jacobite liturgics, especially those of Egypt, there appear to be many more. In one, called after S. Gregory, the very prayer of consecration itself is addressed to our Lord. But this scems to be a remarkable exception; and one might almost imagine that the African canon above quoted, though many years earlicr, was intended to guard against similar invocations, as obscuring the true doctrine, if not directly tending to error. The other addresses to Jesus Christ above referred to, in the several Anaphorre, (for I take no account here of the more distant preparation for the sacrifice,) are most of them private, for the use of the priests, or of each communicant; praying to be made worthy, or giving thanks after communion, or (as in S. Chrrsostom) deprecating the forfeiture of the gift. As far as I see, there is no invocation of our Lord that may be well called public, or congregational, but the response of the people following the words of institution in S. James' and some other Oriental Litureries. Will it be too much to say, that in spite of these exceptions, the clear mind of the Church in her Eucharistical offices has always been to offer the sacrifice directly and immediately to God the Father only? Not as if wc were ignorant how inseparable the Persons of the Blessed Trinity are, nor as if we were excluding the Most Holy Son and Spirit from

g Minor Works, Ans. to P'erron, p. 50, Lib. of Anglo.Cath. Theol. 1858.)
1 Ibicl. $12 \%, 1.12,1.18$

k Ibid. $27,3: 2$.

' Neale, Introduction, 593, 613. 
Chap. III. being truly recipients of the Christian Sacrifice,-which kind of crror was once censured in the Eastern Church ${ }^{\mathrm{m}}$;-but because Holy Scripture everywhere teaches, that it has pleased Him so to order the economy of our redemption, as that each Person shall have His own work therein, to which $\mathrm{He}$ is in a certain sense nearer than cither of the other two: e.g. in the mystery of the Altar, (which in heaven is the mystery of Christ's Intercession,) the Holy Ghost prepares the Sacrifice, the Son offers it (being His own incarnate Self), and the Father receives it. And by Divine instinct, as it may scem, the holy Church from the beginning has been taught to arrange lier liturgies in conformity with this.

$\S 12$. Among the rest, it is obvious to remark that our own reformed Liturgy does not contain any prayer or address to our Lord, until we come to the Gloria in excelsis at the end of it. All along, down to that moment, it is as if He, the true Melchisedec, were condcscending to officiate among us as Priest, marvellously offering up Himself as a memorial of His death; and where He begins, as it were, to re-ascend, then we begin to call on Him in prayer as well as praise. With S. Joln we see Him in the "Lamb standing as it had been slain," now taking His place in the midst of the throne ${ }^{\mathrm{n}}$; and we salute and beseech Him accordingly; as our King, to have mercy on us, and to receive our prayers in His own right; as our Priest, to receive and present them with His own Eucharistical offering to the Father. And then we lose sight of Him (so to speak), as the Apostles did, behind the cloud of glory, where "He only with the Holy Ghost" is " most high in the glory of God the Father." He departs, but not without a blessing, which $\mathrm{He}$ leaves His earthly priest to pronounce in His Name. Ought not all this to be religiously accepted, as one of the many providential tokens that the doctrine of Eucharistical Sacrifice is not abandoned in our Liturgy? God forbid! although by reason of certain deviations from the received language of carly times, omission of some things, and transposition of

meale, Introd, to IIist. of the Holy Eastern Chureh, i. 434.

" Rev. v, 6. 
others, the truth of the blessing is less distinctly taught than Cuar. III. might have been wished.

$\S 13$. The above would seem to be a sufficient reason why congregational prayers and colleets formally addressed to our Lord should not in general have formed part of the Eucharistical services. But we are not hastily to conclude that $\mathrm{He}$ was not intended to be directly worshipped as there present. We have seen that $\mathrm{S}$. Augustine, w' hile discouraging verbal prayers addressed to Him, testifies nevertheless to the fact of His being universally then and there adored, and declares the duty of such adoration:- "We have found out in what sense such a Footstool of our Lord may be worshipped, and not only that we sin not in worshipping it, but that we sin in not worshipping it."

For adoration is by no means limited, as some appear to imagine, to "the saying of prayers." It was observed of old, in answer to an Arian who would fain argue the inferiority of the Holy Ghost from the saying, "that the Spirit maketh intercession for us $\mathrm{s}^{\circ}$ "- - "To intercede or pray, is one thing - to adore, another. Whoever prays, asks, but not every one who adores, asks. Remember the custom of kings: they are commonly adored" with a civil kind of worship, "and not asked for anything. Sometimes they are asked without being adored." Religious adoration is of the heart, and not of the lips only ; it is practised in praise and thanksgiving, as well as in prayer; we adore as often as we approach God in any act of divine faith, hope, or love, with or without any verbal or bodily expression: neither, among postures, is it limited to actual prostration; knecling, or standing with inclination of the body, (venerabiliter curvi ${ }^{\mathrm{p}}$,) was always accepted in most ancient times as a competent attitude of ontward worship.

\$ 14. The absence, then, of special prayer to our Lord sacramentally present in the Eucharist proves nothing against Ifis being adored there; although it is not without significance as an indieation of the sacrificial import of that ordinance. But what shall we say to the deficiency of

- S. Aus. cont. Maxim. Arian. i. 9.

p Ep. of [Pseurlo] Anastasius, ap. Conc. Labbe, ed. Coleti, t. ii. 1429. 
Cuap. III. rubrics? True it is that the extant copics of ancient liturgies are not without special instances sometimes of express direction to adore, sometimes of what is unmeaning without adoration: as in the Nozarabic, after the consecration, and before the Nicene Creed, "the priest elevates the Body of Christ, that it may be seen by the people ";" and the Creed itself is evidently repeated in the way of adoration. In those of the IIierosolymitan family, the rubric and prayer of S. Chrysostom run thus ${ }^{\mathrm{r}}$ :

After the consecration and offering, the priest prays sccretly : " Regard, O Lord Jesus Christ our God, out of Thy holy dwelling-place, and from the throne of the glory of Thy kingdom, and come to sanctify us, Thou that sittest on high with the Father, and art here invisibly with us, and vouchisafe with Thy mighty hand to impart unto us of Thine immaculate Body and precions Blood, and through us to all Thy people. Then the priest adores, and the deacon in his place, saying secretly thrice, God be merciful to me a sinner. And the people likewise all reverently adore. And when the deacon seeth the priest stretching ont his hands, and taking hold of the holy bread in order to make the holy elevation, he says aloud, Let us attend. And the priest: Holy things for holy persons. The choir: There is One Holy, One Lord Jesus Christ, to the glory of God the Father. Amen."

The corresponding portion of S. James' Liturgy runs thus ${ }^{\mathrm{B}}$ : - "The priest secretly: Holy Lord, who restest in the holy, hallow us by the word of Thy graee, and by the visitation of Thy all-Holy Spirit; for Thou hast said, O Lord, Be ye holy, for I am holy. Lord, our God, incomprehensible Word of God, consubstantial, coeternal, indivisible, with the Father and the Holy Ghost, receive the pure hymn in Thy holy and spotless Sacrifice, with the Cherubim and Seraphim, and from me a sinner; crying and saying, (then he elevates the gifts, and saith,) Holy things for holy persons. People: One Holy, one Lurd Jesus Christ, in the glory of God the Father, to Whom be glory for erer and ever. Amen."

$q$ Neale, Introrl. to Hist. of Eastern Church, p. 589.

Ibid. 630-35; S. Chrys., t. vi. 1001. ed. Sav. "Neale, ubi supr. 635, 639. 
And so in S. Mark's, and in the other normal litur- Curp. III. gies.

Who can doubt that where the rubric is wanting in the MSS. the rite was nevertheless remembered and practised? the case being one to which the remark of the learned Renaudot is eminently applicable: "To what end write in the Office-books all the points which the priests and deacons were learning every day by practice in their ministry? Many directories of later ages, later than the time to which the Protestants themselves refer the origin of adoration, contain not a single line on the subject. Aud so it was in the Eastern Churches, where it was comparatively late before any rules for the administration of the Sacraments were set down in writing, and the MSS. consisted of prayers onlyt." To the Eucharist, more especially, this saying will apply, because of the peculiar reverence which induced the Christians of the first ages, living so much as they did among the heathen, to veil the sacred mysteries from the knowledge of all but communicants. So that even in the time of S. Basil, as is notorious, the very words of consecration were accounted among unwritten traditions". And we know how commonly, in unauthorized and popular reprints of our own Prayer-book, the rubrics are apt to drop out.

$\S 15$. Putting all this together, there is nothing in the silence of the Liturgies, so far as they are silent, to outweigh the rlistinct affirmation of so many competent witnesses, backed as they are by intrinsic probability, that the Bread and Wine being once consecrated, the Body and Blood were believed to be present as the Inward Part of the Sacrament, and then and there to be adored; and that a certain moment in the celebration was appointed in each Liturgy, sometimes by rubric, oftener by unwritten custom, for such adoration to take place. One very usual time, pcrhaps the most usual, for this ceremony, was just before the priest communicated, when, having completed the preparation of the holy clements for distribution, he held up one portion of them, to signify to the people that all was realy; at the sane time

- Liturg. Oriental. t. i. 270.

"De Spiritu Sancto, c. 27. 
Crap. III. inviting and cautioning them by the words, "Holy things to holy persons." In other cases, as in the Roman Liturgy, the signification takes place immediately after consccration. In our own, the same end is answered by the provision in the rubric, that the bread must be broken, and the cup taken into the priest's hands, before the people; besides that there is less occasion for it as a notice, when the Sacrament is ministered in a tongue " understanded of the people."

$\S 16$. It is a question seriously to be asked, Can any onc who believes in the Real Presence help adoring, at least inwardly, when he sees or hears either of these signals, or any other equivalent to them. Such an one would need no rubric; and accordingly we find that even in the Canon of the Roman Mass, though the celebrant is directed to adole, no such injunction is given to the communicants or assistants. It is taken for granted, as part of the unwritten mind of the Church. And the same observation will apply to those ancient Liturgies which prescribe nothing on the subject, and perhaps, as we shall see by and by, to our own.

To me this seems to harmonize beautifully with the tenor of the old services, and of all that are in unison with them,the English not the least; - with the fact that the very Creed for a long pcriod was not allowed to be put in writing, and so it came to pass that every diocese almost had its own creed, its own wording for the same Articles of belief; with the similar fact as to Liturgies and Church offices; with many also of the great social rules and rules of discipline; with the many meanings, or shades of meaning, assigned to the same words of Scripture, under the sanction of the New Testament itself, and its way of interpreting the Old, and using the $\mathrm{LXX}$. version. In all these things, taking all Christendom over from the beginning, there is an endless variety in detail, presupposing a perfect unity in principle, such as one might expect in His work, Who made the visible and material world so various, yet so uniform. And thus, as well as by its freeing us from sin, is the Gospel eminently a law of liberty. So much the more striking is it, when in opinions, or interpretations, or formulæ, or usages, which at first appear substantially diverse, or eren inconsistent, we detect a common ele- 
ment animating all, which binds and reconciles all together. Crup. IV. Such is the doctrine of the Real Objective Presence in respect of everything in the Eucharistic offices and traditions, and eminently in respect of the practice of Adoration.

\section{CHAPTER IV.}

TESTIMONY OF THE REFORMED CHURCH OF ENGLAND.

$\S 1$. Alas! that this great, and blessed, and simple truth should have been so marred in its visible effect, and too often, we may fear, in its intended work on men's souls, by the restless curiosity of mere investigators, or the mistaken policy of Church governors; the one speculating, the other defining, on this and other subjects, beyond the lines drawn by Holy Scripture and sacred Antiquity. But this process, be it observel, kept time in a manner with the steps of the unhappy division which the great Enemy was then working out between the Eastern and Western portions of the Church. And so it has come to pass, that for none of the present corruptions, however widely diffused, can it be truly said that there was at any time even a fair semblance of ocumenical authority.

There is no need here to go into the history of Transubstantiation; the introduction of which, erroneously supposed the only alternative with an indevout rationalism, has proved undoubtedly, if not the origin, at least the main aggravation of all our present difficulties on the subject of Holy Communion. But it may bc instructive to remark the difference between the course of synodical decision in the Western Church on this point, and the manner in which the full doctrine of the Incarnation had been affirmed by the great Councils in opposition to the conflicting hercsics of the fifth century. The undivided Chureh in the time of Ephesus and Chalcedon was equally on its guard against Nestorius denying the unity of our Lord's Person, and Eutyches denying the truth of Ilis abiding human Nature: the Scripture and the holy Fathers, it 
Chur. IV. was found and authoritatively declared, were as express and earnest on the one point as on the other. Between the two, the way was marked out without swerving to the right hand or to the left, and all Christendom accepted their witness, and has repeated it all along; with how great a blessing, none may yet know. Who can say how much of the unity in belief, which, blessed be God, as yet prevails among us in spite of so many fretful hearts and undisciplined minds, is due to those solemn assemblies, under the guidance of God's good Spirit?

So it has fared with the doctrine of the Incarnation itself; but it has been far otherwise with the doctrine of the Eucharist, - the extension, as it has been often called, of the Incarnation, and corresponding to it by a very remarkable analogy. Instead of maintaining with the Fathers the full and true co-existence of both parts of the Sacrament, the Western Church, from about the time of the great schism, has allowed and cherished, and finally enforced by anathema, a notion, apparently corresponding to Eutychianism, that the earthly and inferior part is quite swallowed up of the higher, and ceases to be.

$\S 2$. Let it be granted that this riew-as an English Churchman, I must be allowed to call it this error-unlike the opposite one, which would make the Sacrament a shadow, "destitute, empty, and void of Christ," has nothing in it that seems immediately profane, and shocking to a religious mind; nay, more, that it is fully consistent with the very highest contemplations and devoutest breathings of saintly love,-as who can doubt, that has only heard the names of Thomas à Kempis, S. Bernard, S. Anselm, and a hundred others? Yet still, if it be an error, a one-sided formula, a half-truth, on so grave a point of Christian doctrine, it must be an exceeding calamity for any portion of the Cluurch to have committed itself to it; and in process of time it will be sure, one way or another, to betray itself by the appropriate results of error: the tree will be known by its fruits. And Transubstantiation, like certain views which have found more of a home among ourselves, the views (e. g.) of Calvin or of Wesley, however it may have commended itself to many, in their 
deep longing to draw as near as possible to their Saviour, Cuar. IV. must be judged, on a wide view of Church history, and looking to the average sort of belicvers, to have borne on the whole very evil fruit, both where it is received and where it is not. Within the Roman obedience it has been a scandal to the simpler sort by "giving oceasion to many superstitions," it being so exceedingly hard for them to separate it from a base and carnal idea of the Holy Sacrament. Among us, and every where in the West apart from Rome, it has proved a still grcater scandal; it is the one chicf reason of the prejudice which in these later ages has prevailed, and is prevailing (God grant it may not always prevail), against the true and primitive doctrine, which is mistaken for it, like Jehcshaphat in Ahab's robes.

$\S 3$. It is obvious how this prejudice must tell against the rite of adoration especially. Before the time of Paschasius, when it was said, as by S. Augustine or S. Cyril, "the Body of Christ in the Sacrament is to be worshipped," the faithful had been plainly tanght that not the outward sign was mcant, but that of which the bread was the veil. They no more thought of adoring the bread, as such, than S. Mary Magdalen and the Apostles thought of adoring our Lord's garments, when He appeared to them after His resurrection. They worshipped His Divine Person present by the presence of His giorified Humanity : there was no eall or need-if they were devout, there was neither time nor wish-to think at all of the manner of the Frescnce, the earthly substances by which $\mathrm{He}$ was pleased to veil Himself. "They had at that time a sea of comfort and joy to wade in, and we by that which they did are taught that this hearenly food is given for the satisfying of our empty souls, and not for the exercising of our curious and subtle wits." But the teaching of Transubstantiation, if realized at the time, forees men to think of the manner of the Presence, and, to subtle minds, must prore so far a hindrance to devotion, if not a temptation to unbelief. So that even among those who most firmly believed it, the refuge of loving hearts has always been to turn away from it as a topic of Eucharistical meditation, and rerert unconsciously to the simpler faith of the times before such points 
Chap. IV. had been discussed; as we see, (for cxample,) in the last book of Thomas à Kempis. And it has been just the same all along on the other side, with those who feel it a matter of conseience to be denying or doubting that mode of Presence. They have hard work to abstain from thinking of their denials and doubings, when they most wish simply to reeeive the blessing. Thus Hooker limself, after deprecating "the exercise of our curious and subtile wits" on the holy Eucharist, propounds in the very next paragraph an explanation of the words of institution, which, whether it be more or less correet than the Roman, is surely not less "curious" or seholastic:

"My Body, the Communion of MIy Body; My Blood, the Communion of $M I y$ Blood. Is there any thing more expedite, clear, and easy, than that, as Christ is termed our life because through Him we obtain life, so the parts of this Sacrament are His Borly and Blood, for that they are so to us, who receiving them, reeeive that by them which they are termed? The Bread and Cup are His Body and Blood, because they are causes instrumental upon the reeeipt whereof the participation of IIis Body and Blood ensueth. For that which produecth any certain effeet is not vainly nor improperly said to be that very effect whereunto it tendeth. Every eause is in the effect which groweth from it."

The truth is, if one may venture to say it of one so wise, holy, and venerable, that on this subject, as on the Apostolical Succession, and some others, Hooker was biassed by his respect for Calvin and some of his sehool, in whose opinions he had been edueated, and by sympathy with the most suffering portion of the foreign leformers, so as instinctively and unconsciously to hide his eyes from the unquestionable consent of autiquity, and to make allowances which, logically earried out, would lead to conclusions such as the aneient Chureh never could have endured. In this part of his treatise especially, many a thoughtful reader has doubtless wondered, not without some disappointment, at the manner in which he winds up his enunciation of the doctrine of the Eucharist, after fearlessly pouring himself 
out in the most glowing words and most transecndental Crap. IV. thoughts of the deepest and most eloquent of the Fathers :"The Real Presence of Christ's most blessed Body and Blood is not therefore to be sought for in the Sacrament, but in the worthy receiver of the Sacrament." Why? not becanse we are so warned by consent of the ancient Church; not because the words of Holy Scripture are irreconcilable with such an opinion; but because, as it may seem to us, all the purposes of the holy Eucharist may be answered without supposing an objective Presence; an argumeut which, besides other difficulties, obvionsly assumes that we know à priori all the purposes of the holy Eucharist. At the same time, it should be carefully observed that he does not enforce this view as necessary, nor say anything exclusive against the Lutherans, but only that "they ought not to stand in it as in a matter of faith, nor to make so high accompt of it." And then how strikingly beautiful is the conclusion to which, after all, he recurs, his mind floating upward again to its congenial element of love! and how aptly do his words shadow forth the impression which would be left on a dutiful heart by the simple consideration of what Holy Scripture and ancient authors wrote of the tenet which he shrank from-the Real Objective Presence in Sacrifice as well as in Sacrament,--before the unhappy refinement of Transubstantiation came in!- "Where God Himself doth speak those things, which either for height and sublimity of matter, or clse for sceresy of performance, we are not able to reach unto, as we may be ignorant without danger, so it can be no disgrace to confess we are ignorant. Such as love piety will as much as in them lieth know all things that God commandeth, but especially the dutics of service which they owe to God. As for His dark and hidden works, they prefer, as becometh them in such cases, simplicity of faith before that knowledge, which curiously sifting what it should adore, and disputing too bollly of that which the wit of man cannot search, chillcth for the most part all warmth of zeal, and bringetl soundness of belicf many times into great hazard." It cannot surely be wrong to wish that, in this spirit, the spirit of holy humility, all priests may speak, and all Chris- 
Cuap. IV. tians hear, the holy words, "This is Mr Body ; this is MY BLoon;" and if they so speak and hear, how can they help inwardly adoring, even at the very time of consecration? seeing that He does not say, "This will to you and in you be My Body;"'-that is the gloss, not the text;-but $\mathrm{He}$ says simply and positively, "This is My Body;" and again, "This Is My Blood."

$\S 4$. But you fear to surrender yourself to this impulseyou fear to adore before you eat-lest you should be unawares committing yourself to a kind of idolatry, in worshipping Bread and Wine; or to a gross material couceit, like that whieh our Lord reproved in the multitude at Capernaum; as though, if the sight were not miraculously withheld, they would behold Him corporally in His human form and features; and how then could they dare partake of Him? We have too much reason to believe that the latter of these errors has been, perhaps is still, not uncommon among the uneducated in neighbouring countries; and as to the former, it is involved in the very notion of Transubstantiation, supposing that notion untrue. To worship the outward part of the Sacrament must, of course, (to use a school distinction,) be material idolatry in their cyes who have learned and believe that it is true Bread and Wine; although in those whose faith teaches them that there is really no outward part, that the holy Body and Blood are alone present, such worship can hardly be formal idolatry, nor in any degree (we may hope) incur the guilt thereof. No wonder, however, if the mind, haunted by this idea, shrink more or less from the thought of any worship in the Eucharist. And yet, when we reflect on it in earnest, how can the heart help worshipping? 'The remedy must be, to place yourself, by God's help, with courageous faith, in the same posture of mind with the ancient undivided Church before these theories were invented; simply to adore, from simple conviction of Christ's presence. For many generations all good Christians did so without fear or scruple: not because they were unaware of the possibility of these later errors, for they were distinctly warned against them by their teachers; Theodoret, as against Transubstantiation, declaring that "the mystical 
symbols in no wise depart from their proper nature; for Crap. IV. they remain in their former substanee, and figure, and kind, and are visible and tangible, just as they were before $x$;" S. Angustine, as against Carnal Presenee, pointing to our Lord's cautionary words: "When thou adorest Him, lest thy mind linger in the flesh and thou fail to be quiekened by the Spirit, 'It is the Spirit,' saith He, 'that quiekeneth, the flesh profiteth nothing.' ... Some of His disciples . . . took foolishly what He had said; they had carnal thoughts of it, and imagined that our Lord was to separate certain particles from His own Body, to give unto them. ... . But the Twelve having remained, He instructed them, and said unto them, 'The words that I speak unto you are spirit and life.' Understand what I have said to you spiritually; it is not this Body which you see, that you are to eat, nor to drink that Blood which they will shed who shall crucify Me. It is a certain Sacrament which I have entrusted to you; spiritually understood it will give you life. Though it must needs be visibly celebrated, it is meet to be thought of as something invisible $8 . "$

Theodoret and S. Augustine, be it observed, are two of the most express witnesses to the adoration of Christ's Body in the Eucharist.

$\S 5$. It will be said-it has been said again and again; it was the primary argument of those who were accounted "sober Churchmen" a century ago-that it might be very well for the primitive Christians to speak such language as they did, and practise such ceremonies, but that the misehiefs in which that coursc eventually issued were a providential warning to us not to tread in their steps. And no doubt there are cases to which this topic may and ought to be applied. But they must be cases of detail, not of principle. The Church must look well to it, that in no instance the opinion or rite surrendered be such, as that the loss of it shall materially damage any one of the great truths or duties eommitted to lier charge. To take instanees from the ritual of the Eucharist itself : the suppression of the apostolical feasts of charity, or, in later times, of the kiss of peace, no one,

× Eramistes, Dial. ii., ed. Schulze, t. iv. p. $126 . \quad$ g In Ps. 98 [99]. \$ 9. 
Снар. IV. under the circumstances, would think of deprecating. But it is far otherwise when we are dealing with such great fundamental matters as the Real Presence, and adoration consequent upon it. The doctrine, if revealed at all, is revealed for ever; the homage, if due at first, must be due always: it cannot be innocently suspended or done away. For the observation of Bishop Butler on the worship of the Second and Third Persons of the Most Holy Trinity-in what sense it is a moral duty-may be applied with much seeming reason to this case. "The worship," he may be understood to say, "the internal worship itself," before defined to be "the religious regards of reverence, honour, love, trust, gratitude, fear, hope," to Christ present in the holy Eucharist, "are no farther matter of pure revealed command, than as the fact of" that Presence "is matter of pure revelation; for the fact being known, the obligations to such inward worship are obligations of reason arising out of the fact itself $z_{\text {." }}$

Should abuses then occm, they must be met by explanation; but far be it from the Church of God to permit any abuse of man to take away the use of His merciful gifts. That would be simply lending ourselves to the purposes of the crafty One who prompted the abuse. To him it is all one, if he can but turn you away from Christ, whether he do so by unauthorized veneration and worship, or by unloving and faithless fear of that which is authorized. Just as in the period of the great CEcumenical Councils, he cared not to make men Nestorians rather than Eutychians. His single point was to disturb, at all events, their faith in our Lord's Incarnation. And how did undivided Christendom meet him? By simply and steadfastly abiding in the old ways. Courageous in their charity, and charitable in their courage, they held fast the whole truth, only guarding it on the right hand and on the left by necdful and considerate explanations; yet not they, "but the grace of God which was with them."

\$6. To what extent that grace may have been forfeited and withdrawn, by reason of the manifold sins and divisions of God's people in the following ages, we can but surmise with fear and trembling. But we of the reformed Church

"Anal., p. ii. c. 1. Works, Oxf. 1807, rol. i. p. 212. 
of England are most surely bound by a deep debt of gra- Curs. IV. titude to Him, who in most eritical times so overruled the course of religious change in this country, as to preserve us in many signal instanees from most imminent peril of giving up something essential for dread of accidental error. One of these instances, if I take it aright, is the matter of adoration in the Eucharist.

For what in very deed is the drift of the Admonition at the end of our Liturgy, so often quoted as forbidding all adoration? Take the words in their literal and grammatical sense: "It is ordained in this Office for the Administration of the Lord's Supper, that the communicants should receive the same kneeling; (which order is well meant, for a signification of our humble and grateful acknowledgment of the benefits of Christ therein given to all worthy receivers, and for the avoiding of such profanation and disorder in the Holy Communion, as might otherwise ensue)."

Kneeling, in a chureh, and in divine worship, is a posture of adoration-one of the three recognised postures; and where it is especially prescribed, some especial adoration must be intended. To whom? and for what? The words themselves of the protestation answer the latter question. We kneel in receiving "for a signification of our humble and grateful acknowledgment of the benefits of Christ therein given to all worthy reeeivers."

The grammar of this may be a little uncertain; i.e. it does not quite clearly appear whether Christ Himself, or His benefits, are said to be given in the Sacrament. But in meaning and effect the phrases are plainly equivalent. Coming worthily, we are therein "partakers of Christ,"of Christ present in His luman nature by the presence of His Body and Blood,- - a Presence hidden from us, but certified by the consecrated bread and wine which we do sec. All who believe this - and this surely is no more than the Catechism plainly teaches us all,--must they not of course feel, that in kneeling down to receive the Iloly Communion, they are in fact kneeling to Him who is come to give Himself to them; kneeling to His Person, to His human nature, to His Body and Blood; as truly, vcrily, and indeed, 
CHap. IV. as if they had been kneeling on Calvary itself, at the foot $o_{1}$ the real Cross?

And who shall dare to come and tell them that in so feeling, so bowing before that Presence, in the most perfect homage their hearts can attain to, they are going beyond the rule of "humble and grateful acknowledgment of the benefits of Christ, therein given to all worthy receivers?" The real question is, what is the benefit received? If it be Christ IIimself, not His grace and help only, surely "humble and grateful acknowledgment of the benefits of. Christ" cannot mean less than adoration.

I must take leave then to say, that granting the doctrine of the Real Objective Presence, Adoration is not only permitted, but enjoined by the Church of Lingland in her Prayer-book. Those who would prove that she prohibits the one, must first make out that she denies the other; which they can never do as long as her Catechism and her Communion-office remain.

§7. But now mark how wisely and charitably, guided, no doubt, by God's good providence, our Anglican Church, in asserting for her children the full right and duty of simple and primitive worship, disavowed on their behalf errors which experience had shewn were likely to be laid to their charge, and provided them also with a ritual rule, which would guard them from seeming to fall either into those errors or the contrary. The rule is most simple, yet most effective; it is just this, - that whereas in the Church generally great freedom has been allowed to communicants to adore in what posture they would; standing generally, at least on festivals, in the first ages, afterwards for the most part knecling, but with permission to those who felt such an impulse, to prostrate themselves in the mysterious Presence;-this liberty is now so far curtailed among us, that we are all (if health allow) bound to receive kneeling; which, being on the one hand a posture of adoration, answers the purpose of a "humble and grateful acknowledgment ;" on the other hand, it avoids the semblance of that worship which to most.men's fancy had unhappily come to imply belief in Transubstantiation. It also guards against a certain "profamation and disorder," not 
of course intentional, but sure to occur, where some kneel Cinap. IV. and others fall prostrate; as well as against the worse profanation of sitting, or using other eareless postures, according to the custom of those Christians who have a superstitious fear of the Real Presenee.

Nay, and there is something to be said of it yet more serious, - so serious, that I will repeat it, though it has been mentioned above. What Hooker writes of the customs of standing up when the Gospel is read, and of bowing at the Name of Jesus, seems even more applicable to the rite of adoration in the Holy Communion; "Against infidels, Jews, Arians,"-he might have added, Nestorians-"who derogate from the honour of Jesus Christ, such ceremonies are most profitable." Ald accordingly, "it is observed by the Polish Church in their 'Consensus,' that 'the men who lapsed there into the Arian hercsy were all such as addicted themselves to the posture of sitting at the Communion a." "

And no wonder; for in refusing to adore on that occasion, (supposing them to know what they did,) they had betrayed themselves at least to be very imperfeet believers; there being no outward act which does so entirely gather up, as it were, the whole Catholic faith in one, and declare it before the eyes of men, as receiving the holy Eucharist with a gesture of adoration. This any one may easily understand, who will just go through in his mind the screral articles of that faith, and pause to consider how enelı one is symbolized in, or associated with, the Great Sacramental Rite. For instance: by receiving His creatures of Bread and Wine, we acknowledge Ilim (as S. Irenæus argues) Creator of heaven and carth, against all sorts of Manicheans : receiving Christ's Body is confessing His Inearnation; and adoring it, His Divinity; it is the memorial of IIis death, and the partici. pation of that Sacrifice which supposes Him raised and ascended into heaven; it is obeying llis command, so to shew forth His death till He come; it is drinking "into one Spirit;" it is partaking of that "one Bread" which makes us "one Body," the IIoly Catholic Church; it is "the Communion of Saints;" it is the Blood shed "for the re-

- 1'Wstrange, Alliance of livine Offices, c. vii. p. 323.

k 2 
Chap. IV. mission of sins ;" it is the last Adam coming to be in us a quickening spirit, to seal us for "the resurrection of the body, and the life everlasting."

$\S 8$. For reasons such as these, as we may well imagine, the Church of England in 1661 declined either to abolish or to leave optional the rite of kneeling to receive the holy Eucharist, but rather desired to retain it with cautionary words. And the cautionary words are evidently intended not so much for the communicants themselves, as for others who might be inclined to misinterpret the ceremony. The framers of them clearly indicate that they would have been best pleased simply to leave those committed to their charge to follow the dictates of natural picty, which, of course, would lead them to adore. But knowing the misconstructions which are abroad, they charitably protest " that thereby no adoration is intended, or ought to be done, either unto the Sacramental Bread or Wine there bodily received, or unto any corporal Presence of Christ's natural Flesh and Blood." This is not the language of persons intending to negative all idea of any adoration whatever in the Eucharist. Had such been the mind of the Reformers, it was easy for them to speak it out; they might simply have said, "No adoration is intended unto the Sacrament, or either part of it." But what they have really said amounts to this: We not only permit, but enjoin, all communicants to worship Christ present by the peculiar mystery of the Sacrament; and all objectors are desired to take notice that this implies neither Transubstantiation, nor any sort of natural and local presence. For as to Transubstantiation, "the Sacramental Bread and Wine remain still in their very natural substances, and therefore may not be adored; (for that were idolatry, to be abhorred of all faithful Christians)." And as to material Presence, "the natural Body and Blood of our Saviour Christ are in heaven, and not here; it being against the truth of Christ's natural Body to be at one time in more places than one." That Body which was seen by S. Stephen, S. Paul, and S. John, "is in heaven, and not here." As a true natural Body, it is one, and it has its own dimensions and outline, whereby it was recognised by those 
blessed disciples; and in respect of that form (to use the Cuap. IV. words of Aquinas), "the Body of Christ is not but in one place only, i.e. in heaven "."

These two errors then are excluded, viz. such a change in the Bread and Wine as would destroy the Sacrament, by annihilating its outward part; and such a "diffusion c" of the Lord's Body into all places as would make it cease to be His own true natural Body. But no kind nor degree of worship, as towards the inward part of the Sacrament, apart from those errors, is in any degree censured or forbidden; on the contrary, such worship is, as we have seen, implicitly commanded in the preamble of the Admonition. It is as if the Church should say, "You see me and my children adoring, - of course we must do so, sinee we know and belicve that here are verily and indeed present the Borly and Blood of the Lord, to be taken and received by the faithful; but you are not therefore to tax us with this or that human interpretation, which we hereby renounce." Is this unduly straining the expressions of the protestation? I think not, for obvious and well-known reasons.

$\S 9$. First, the significant change in the words of the document,- the history of which appears to be as follows. In the beginning of the second year of Edw. VI., Narch 8, 1548, a "Communion-book" was issued, pending the complete revision of Church Offices, which was known to be going on; in which book the rubric at the time of receiving is, "Then shall the priest rise, the people still reverently kneeling "."

In the end of the second year, or beginning of the third, the first Prayer-book became law: in the Communion-office of which no direction for the posture was given ; but in " ecrtain notes" at the end of the book we read, "As touching kneeling, crossing, holding up of hands, knocking upon the breast, and other gestures; they may be used or left as every man's devotion serveth, without blame e."

It would appear that this licence tended, on the whole, to irreverence: it could hardly be otherwise, seeing that

$\checkmark$ iv. A. 10,1 ad 5, t. xii. 193.

c seo llooker, Eecl. Pol., V. lv. 6. d Cardwell. 'Two Liturgies, de. p.431.

- Ibil., 397. 
Cuap. IV. before it was granted, proclamations and acts of parliament to check profane talking about Holy Communion had been thought necessary by King Edward's Bishops and couneillors, and in 1553 especially, encouragement had been given to Alasco, and other earnest importers of low Zuinglianism. From incidental sayings here and there in Strype, we may imagine to what lengths the evil had gone: and it may have been the apprehension of it, joined probably to the influence of Ridley, which caused the revisers of 1552 positively to enjoin reception in a kneeling posture; though they could not but be well aware, what fierce and lasting opposition that rubric was likely to encounter. Puritanism was too evidently in the atmosphere for such discerning watchers to be ignorant of it, and by this we may perceive how serious a principle they judged to be involved in the step they were taking.

The new Prayer-book, thus enjoining, as I should say, adoration of that which is unseen in the Sacrament, and so, if Strype speak truly, interpreted by many, came into use by act of Parliament on All Saints' Day, 1552 f. "But because the posture of kneeling was excepted against by some, and the words used by the Priest to the communicant at the reception of the Bread gave scruple, as though the adoration of the Host were intended; therefore, to take off this, and to declare the contrary to be the doctrine of this Church, October 27, a letter was sent from the Council to the Lord Chancellor, to cause to be joined to the Book of Common Prayer, lately set forth, a declaration signed by the King, touching the kneeling at the receiving of the Communion."

It is remarkable, and may serve to indicate a great conflict of opinion in the couneil, that although the act establishing the new Liturgy had passed before April 16, it was not until October $2 \%$, just four days before the book was to come into use, that the gorernment made up their minds to insert this protestation. Of course, so inserted by order of eouncil only, it had no authority of parliament. A conrocation was summoned for the following September, but the king's death in July prevented its assembling. So far, the protestation

$f$ Life of Crammer, b. ii. c. 33 . 
we are considering had neither the anthority of the Church Cirar. IV. nor of the State.

$\S 10$. On the accession of Queen Elizabeth, it eame of course into discussion with the other contents of King Edward's book. But in that revision it was omitted, and the rubric for kneeling simply retained, without any explanation, although it appears from a paper in Strype ${ }^{g}$ that the posture of the communicant was left free-frec, that is, as between standing and knceling (both which are postures of adoration)in the first draft of the bill prepared by the divines for parliament. As far as Strype knew, the single emendation adopted by the first parliament of Elizabeth in the Common Prayer as submitted to them, was making the posture of kneeling compulsory. And according to all the experience of that reign, we may well suppose this due to the influence of the Queen; and it may perhaps be set down (especially if we comnect it with the omission of the explanatory note of King Ed. ward's couneil) as one of the instances in which Elizabeth's Catholic tendencies succeeded in counteracting the exclusiveness of many of her people and some of her ministers. It betokens the same faith in the Real Presence, and sympathy with those who maintained it, as did the eross and lights which she continued in her private chapels, in spite of so many remonstrances from her chaplains of the Frankfort and Genevan schools, and from her councillors, who feared their influence with the people. Nor can we in any more probable way aecount for the remarkable enactment and rubric -just now the object of so much attention-which have been supposed to form the standard of our ritual in such matters: - "The minister at the time of Communion, and at all other times in his ministrations, shall use such ormaments in the church as were in use by anthority of parliament in the second year of King Edw. VI., according to the act of parliament set forth in the beginning of this Book."

This second of Edward VI. is precisely the last year in which the ritual of the unreformed Chureh was in the realm by authority of parliament: I mean, of course, in all matters whieh had not been specially interfered with. For the First 
Cmap. IV. Book of Edward, the first reformed Liturgy, did not come in use by authority of parliament until Whitsunday, 1549, which fell far within the third year of Edward VI. Therefore, strange as the assertion may sound, and unadvisable as, of course, it would be to affect to carry it out, it would perhaps be true to say, that the Chureh ornaments and furniture then com. mon here, and now among the Lutherans, were not only tolerated, but enaeted under penalties by the law of Lngland in Elizabeth's time. One eannot suppose so wide and serious an enactment, touching so many, as it were, in the apple of their eye, to have passed in mere inadvertence. What more probable than that the Queen, as her known inclination and after conduct would lead us to expect, threw her weight-decisive, of eourse-into the scale of those who wished to preserve or restore the old ornaments, and that the arrangements of her private chapel were intended to be strictly conformable to the law so interpreted? Thus, when Parker first, and afterwards Cox and others, remonstrated with her on those praetiees, we do not find it alleged by them that her Majesty was violating the law of the land: yet this would surely have been among their topics, had they put the same eonstruetion on the rubrie which has since become familiar to us. Their arguments are all drawn from the seeond commandment, the peril of idolatry, and the like. And when they would proeed in their dioeeses against the obnoxious ornaments, we find them obtaining "injunetions from the Queen's Majesty,"-I suppose under the last part of the twenty-fifth clause of the Act of Uniformity; whieh seems to imply that if she withheld her injunction the ormament would not be illegal: otherwise each bishop might have acted at once for himsclf.

$\S 11$. Under such a state of the law, and with sueh a disposition on the part of the sovereign, began the long years of eonflict with Puritanism, throughout which this question of the reeeiver's posture at Holy Communion supplied an outward and visible symbol of the deep doetrinal differences which were really at issue. And when the Prayer-bouk came once again under authoritative review at the Restoration, then, and not until then, (it being determined that 
the posture of kneeling should still be compulsory,) was the Crap. IV. Admonition of 1552 adopted by the Church in Convocation, as part of our present Prayer-book, and legalized, as all men know, by the second Act of Uniformity.

It may be asked why, if the tenor of that Admonition be really so favourable, as I have now alleged, to the doctrine of the Real Presence, and to legitimate adoration, was it rejected by Queen Elizabeth, and by the parliament under her influence? In answer it may be sufficient to refer to one brief but pregnant alteration, familiar to all who have looked at the history of the Prayer-book, which the divines of 1662 made in the document before they adopted it. King Edward's Council had said, "We do declare that it is not meant thereby that any adoration is done or ought to be done, either unto the sacramental bread and wine there bodily received, or to any real and essential Presence there being of Christ's natural flesh and blood." But the Church of England in the Prayer-book of 1662 declared, and still continues to declare, the same concerning any corporal Presence. "Corporal" is not equivalent to "real and essential." It is not only associated with grosser and more carnal ideas, but in its strict philosophical meaning implies also something local, in the sense of filling a certain space;

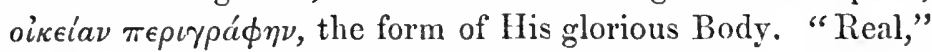
"substantial," "essential," imply nothing of the kind. They express our faith in the miracle, without in the least pretending to indicate the manner of it. By the very change liberty is left, and must have been intended to be left, to adore Him, as the Cateclism had taught us to believe Him, really, substantially, essentially present. That permission is as plainly implied as the prohibition to worship Him "corporally" present is expressed. Such, no doubt, was the meaning of divines like Ridley in 1552; although the form which they were led to adopt was unfortunately capable of a much more questionable interpretation. It is probable, too, that Queen Elizabeth, both in principle and in policy, would wish to leave such questions open, as far as might be, on the Roman as well as on the Lutheran side; and for the same reason that the Thirty-nine Articles, and amongst them 
Cusp. IV. the sentence against Transubstantiation, were not entirely adopted by the Church of England until 1571, this declaration also might be advisedly omitted.

$\$ 12$. We can hardly be wroug in this interpretation of the clause in question; for it has more or less warrant from the very divines who had the chicf hand in that last revision of the Liturgy. Bishop Cosin, e. g., in his first set of Notes on the Prayer-bookh, feared not to say, "It is confessed by all divines, that upon the words of consecration the Body and Blood of Christ is really and substantially present, and so exhibited and given to all that receive it; and all this not after a physical and sensual, but after a heavenly and invisible and incomprehensible manner: but yet there remains this eontroversy among some of them; whether the Body of Christ be present only in the use of the Saerament, and in the act of eating, and not otherwise. They that hold the affirmative, as the Lutherans (in Conf. Saxon.) and all Calvinists do, seem to me to depart from all antiquity, which places the Presence of Christ in the virtue of the words of eonsecration and benediction used by the priest, and not in the use of eating of the Sacrament; for they tell us that the virtue of that consecration is not lost, though the Sacrament be reserved, either for sick persons or other. Whereupon Cassander, quoting S. Cyril on S. Luke, saith, "They are mad who say that the mystical benediction of the Sacrament eeaseth, or loseth its virtue, if any remains stand over for days to come; for the holy Body of Christ will not be changed, but the virtue of the benediction and the lifegiving grace is perpetual in it.' And this did most of the Protestants grant and profess at first, though now the Calvinists make popish magic of it in their licentious blasphemy."

Here it is very observable, that Cosin adopts (it must have been on purpose) a phrase equivalent to that which King Edward's Council, or rather Bueer speaking through them, had recommended the Church of England to disown and deprecate. Bucer wanted to make us all say, "No adoration is done, or ought to be done, . . . . unto any real and essential Presence there being of Christ's natural Flesh and Blood."

b Works, Anglo. Catth. Lib., v. 131. 
Cosin says, "The Body and Blood of Christ is really and Crap. IV. substantially present."

So far, at any rate, Bishop Cosin continued in the same mind, when he bore his part-apparently, a principal part - in the arrangement of our present Liturgy. And in his third series of Notes on the Prayer-book, v. 480, he remarks with evident satisfaction, that "this rubric, by the tenor of it, seems to be no part of the Prayer-book;" not being, it would seem, aware of its history, but struck, as any one might be, with the expression, so and so "is ordered in the Book of Common Prayer;" not at all a natural way of speaking, if the sentence were itself part of the book.

At a later period Cosin quotes from Calixtus, with general approbation, the following sentence: "Dum accipiunt, in genua procumbentes, Christum Dominum, qui presens eis digne edentibus et bibentibus adest, suumque corpus manducandum, et sanguinem bibendum exhibet, venerantur et adorant; non quidem elementa in sacramentum significata, quæ adoranda non sunt, sed ipsum Dominum et Deum nostrum Jesum Christumi." This, I own, Cosin qualifies so as to limit the Presence to the faithful receiver, and to the very moment of receiving; and so far he withdraws his former, and, as I conceive, his more primitive, opinion; still, howcver, implying, that wherever there is Sacramental Presence there cannot but be special adoration, only not directed to the outward part or sign, but to the thing signified,-Christ's Person, present by the Presence of His Body and Blood.

Whatever he withdrew, it is plain that he had not withdrawn his faith in the Real and Essential Presence, and in the dutiful necessity of adoring our Lord so present. Nor is it irrelevant to remark, that had Cosin had his own way in all points, the order of our Liturgy would have been brought as near to that of King Edward's first Book as the first Scottish office was, and as the American is now. In particular, the Prayer of Oblation and the Lord's Prayer would have come between Consecration and Communion. This we may surcly consider to be a clear indication what he thought of the doctrine of Eucharistical Sacrifice. And we

\footnotetext{
i Works, Anglo-Cath. Lit., v. 315.
} 
Char. IV. may infer that he never would have sanctioned our present order, had he regarded it as inconsistent with that doctrine.

And with regard to the first-quoted passage, in which Cosin had asserted not only a Real and Substantial, but also a Real Objective Presence from the moment of consecration; it may be neutralized on that point, as far as he is concerned, by what he afterwards wrote; but this does not destroy the force of the same passage as an evidence of Bishop Overall's mind on the subject. Cosin, as is well known, was Overall's chaplain and disciple; and to him, in the first set of Notes especially, he all along refers with entire reverence. We may take it for granted that on such a point Cosin, in his earlier days, would not speak positively without his master; and we may conclude with some confidence that Overall held strongly the doctrine of Christ's Presence immediately after consecration, and not in the faithful receiver only.

And Overall is the author of the section on Sacraments in the Catechism. He it is who has taught us all from our childhood, that Christ's Body and Blood are the inward part of the Lord's Supper, coëxisting with the outward part-with Bread and Wine, over which the words of Christ have been spoken by one who is for that purpose as Christ Himself.

$\S 13$. There were other revisers in 1661, whose views on this subject are either declared by themselves, or may be with tolerable certainty conjectured from other facts known concerning them. Bishop Wren, of Ely, for example, at whose house, by reason of his extreme age, the conferences were held, had been one of those most prominent in acting under Laud, and enduring persecution with him for Christ's altar's sake. Now Laud's principle as to the Real Presence appears in a remark on Bellarmine, who had said, "The Conversion of the Bread and Wine into the Body and Blood of Christ is substantial, but after a secret and ineffable manner." "Now," says Laud, "if he had left ont 'conversion,' and affirmed only Clirist's 'real Presence' there, after a mysterious, and indeed an ineffable, manner, no man could have spoken betterk."

k Conf. with Fisher, Works, A.-C. L. ii. 322. The whole argument in that

plaee assumes, that exeept in regard of 'Trinsubstantiation and its corol: 
His principle as to adoration was, "The altar is the great- Crap. IV. est place of God's residence upon earth-greater than the pulpit; for there 'tis Hoc est Corpus meum... but in the other it is at most but IIoc est verbum meum; and a greater reverence is due to the Body than to the Word of the Lord"." But "When this reverence is performed, 'tis to God as to the Creator, and so divine; but 'tis only 'toward,' not 'tu' the altar, and so, far shortm.' This is just the principle of kneeling at the Eucharist, as I suppose it to be explained in the Protestation of 1661 . That reverence is done "to" the Body and Blood, as to the Person of Christ there present in a special way; but only "toward," not "to," the elements, and "so, far short." Or, as it is less quaintly expressed in the Scottish Canons of 1636, ch. vi. can. $6^{\mathrm{n}}$ : "Superstition and profaneness are both of them extremities to be avoided: as therefore the adoration of the bread is condemned, so the unreverent communicating, and not discerning of those holy mysteries, must be eschewed. Therefore it is ordained, that the Holy Sacrament of the Lord's Supper be received with the bowing of the knee, to testify the devotion and thankfulness of the receivers for that most excellent gift." The seventh English Canon of 1640 recommends "reverence and obeisance," not "upon any opinion of a corporal Presence" . "but only for the advancement of God's Majesty, ... and no otherwise ${ }^{\circ . " ~ I t ~}$ will be scen on comparing these citations, that in Laud's opinion, denying a corporal Presence was not inconsistent with believing a substantial Presence. It was not that his opinion had altered when he issued the Canon. For, 1. The Conference was published by him only in 1639, and the Canon dates from 1640. 2. In his last will he directs the Conference to be "translated into Latin and sent abroad, that the Christian world may see and judge of" his "religion."

laries, our doctrine of the Fucharistical Presence is the same as the Roman. 'Lnud's Works, A.-C. L. iv. 284.

n Ibid. 285.

n Ibid. v. 574.

- Ibid. 626. The "no otherwise" is clearly meant to disavow the calum- nious imputation of Burton and others, that in gestures of reverence to the Church or Altar "we worship the holy Table, or God knows what." Speech at the Censure of Bastwick, \&e. vi. pt. i. p. 57. 
Cимp. IV. $\$ 14$. If Bishop Wren may be justly regarded as an exponent of Laud's doctrine, Bishop IIenchman of Salisbury, another of the revisers, may seem to stand in the same relation to George Herbert. This is Walton's statement concerning them. At the time of Mr. Herbert's being ordained priest, "the lev. Dr. Humphrey Henchman, now Lord Bishop of London, (who does not mention him but with some veneration for his life and cxcellent learuing), tells me he laid his hand" (being then a prebendary of Salisbury) "on Mr. Herbert's head, and alas! within three years lent his shoulder to carry his dear friend to the grave." Now Collier says of the same Bishop IIenchman, "He is reported well acquainted with the Fathers and Councils." He at the Savoy Conference "discoursed with great temper, but was strongly against large abatements and schemes of comprehension. This prelate, together with Sheldon and Morlcy, is said to have had the chief management of this affairp." One should not expect from this, that Bishop Henchman would fail to sympathize with Herbert on such a point as the Real Presence. Now what Herbert thought of that doctrine, and of the consequent practice of adoration, has been shewn alrcady, and may be further judged of by what follows:"The Country Parson ... especially at Communion-tines, is in great confusion, as being not only to receive God, but to break and administer Him. Neither finds he any issue in this, but to throw himself down at the Ihrone of Grace, saying, Lord, Thou knowest what Thou didst, when 'Thou appointedst it to be done thus; therefore do Thon fulfil what 'Tlou didst appoint: for Thou art not only the Feast, but the way to itq." ",

Bishop Earle, then Dean of Worcester, another friend and neighbour of Herbert's, was on the commission for discussing the Prayer-book with the Presbyterians. It was not likely that he, any more than Henchman, wonld deliberately sanction a formula which must have cast Ilerbert out of the ministry.

I may mention also Sparrow, afterwards Bishop of Exeter, who, in his "Rationale of Common Prayer," p. 236, gives p ii. 885 , fol.

${ }^{9}$ c. 22. 
the following account of the posture enjoined at the Eucha-Crap. IV. rist: "It is to be given to the people KNEELING; for a sin it is not to adore when we receive this Sacrament." "And the old custom was to receive it after the manner of adoration." For which he quotes S. Augustine and S. Cyril.

Bishop Nicholson also, of Gloncester, one of the final revisers, writes thus of the holy Eucharist: "All the words used by Divines in this Mystery may receive a candid interpretation, except that of Rome. 1. That Christ is in the Sacrament corporally, substantially, and perhaps consubstantially, may have a respect to the subject or supposite, of the relatum and correlatum, their meaning no more than that $\mathrm{He}$ is there under the forms of Bread and Wine, not changed in substance but in use; as it is in other relations; as e.g. betwixt a father and a son; who though they relate to each other, yet they remain two distinct substanees, and the same they were ${ }^{\mathrm{r}}$."

Thorndike's view is expressed in the following passages, among others. "I suppose that the Body and Blood of Christ may be adored, wheresoever they are." ... "And is not the presence thereof in the Sacrament of the Eucharist a just occasion, presently to express by the bodily act of adoration that inward honour which we always carry towards our Lord Christ as God?" ... "I do believe that it was so practised and done in the aneient Church; which I maintain from the beginning to have been the true Chureh of Christ, obliging all to conform to it in all things within the power of it." . . . "For I do acknowledge the testimonies that are produced out of S. Ambrose, S. Augustin, S. Chrysostom, Theodoret, S. Gregory Nazianzen, S. Jerome, ;Origen : where he teacheth to say at the receiving of the Sacrament, 'Lord, I am not worthy that Thou shouldst fcome under my roof :' which to say, is to do that which I conclude. Nor do I need more to conclude it. And what reason can I have not to conchude it? Have I supposed the elements . . . to be abolished? or any thing elsc concerning the Flesh and Blood of Christ or the presence thercof in the Eucharist,-in giving a reason why the Church may do it,-which the Church dit 
Cuap. IV. not belicve? If I have, I disclaim it as soon as it may appear to me for such s."

But it is needless to multiply single testimonies, since we are able to cite the allegation of the members of that venerable commission as a body. "The posture of kneeling best suits at the Communion as the most convenient, and so most decent for us, when we are to receive as it were from God's hand the greatest of seals of the kingdom of heaven. He that thinks he may do this sitting, let him remember the prophet Malachi, 'Offer this to the prince, to receive his seal from his own hand sitting, see if he will accept of it.' When the Church did stand at her prayers, the manner of receiving was more adorantium, (S. Aug., Ps. xcviii.; Cyril. Catech. Mystag. 5,) rather more than at prayers; since, standing at prayer hath been generally left, and kneeling used instead of that, (as the Church may vary in such indifferent things). Now to stand at Communion, when we kneel at prayers, were not decent, much less to sit, which was never the use of the best times."

Observe how studiously they refer to the practice of the ancient Church : according to their own principle set in the forefront of their reply, "The Church hath been careful to put nothing in the Liturgy, but that which is either evidently the Word of God, or what hath been generally received in the Catholic Churcht." And again, "If by 'orthodox' be meant those who adhere to Scripture and the catholic consent of antiquity, we do not yet know that any part of our Liturgy has been questioned by such"."

And the two references to S. Augustine and S. Cyril, and the phrase more adorantium, sufficiently shew that they, who first gave Church authority among us to Bucer's amended protestation, intended by the rule of kneeling at Holy Communion at least to tolerate that which the Fathers meant, when they spoke of worshipping " the earth which our Lord took of the Virgin Mary,"-His Body and Blood, sacramentally but most truly present, in some way known to God, with the consecrated elements.

$s$ Of the Laws of the Church, c. xxxi. $\$ 1,4,5,6$.

'Collier, ii. 883 ; Cardwell, Hist. of Conferences, 337. Ibid. 338. 
This construction of the rubric in question seems to be Crap. IV. confirmed by two or three circumstances in the Conference which led to its adoption. First; one of the "exceptions of the ministers" against the Book of Common Prayer having been expressed as follows, "We should .. have our Liturgy so composed, as to gain upon the judgments and affection of all those who in the substantials of the Protestant religion are of the same persuasions with ourselves :" the Bishops in answer say, "It was the wisdom of our Reformers to draw up such a Liturgy as neither Romanist nor Protestant could justly except against; and therefore as the first never charged it with any positive errors, but only the want of something they conceived necessary, so it was never found fault with by those to whom the name of Protestants most properly belongs, - those that profess the Augustan Confession ${ }^{\mathrm{v}}$." Could they have said so, if they had accounted the doctrine of the Eucharist as taught in that Confession untenable in the Church of England? could they have meant to make it untenable by the rubric which they presently afterwards sanctioned?

2. The Commissioners did but unwillingly entertain the proposal for re-introducing that rubric: their first reply to it was", "This rubric is not in the Liturgy of Queen Elizabeth, nor confirmed by law; nor is there any great need of restoring it, the world being now in more dangcr of profanation than of idolatry. Besides, the sense of it is declared sufficiently in the 28th Article of the Church of England." Upon which it plainly follows, that whatever account may be fairly given of the terms of that Article, as compatible with a Real Objective Presence, the same is applicable to the admonitory rubric, as intended by those who framed it.

3. Burnet ${ }^{x}$ informs us that the eventual concession of the Commissioncrs on this point was cliefly due to the efforts of Bishop Ganden, but that it was in a great measure neutral. ized by "P. G." (Peter Gunning), who procured the significant alteration in the terms of the rubric, "corporal" being substituted for "real and esscntial," - a change which Burnet himself evidently regrets, intimating thereby that it was gene-

- Cardwell, Hist. of Conferences, 305,338 . 
CHAP. IV. rally considered as leaving the point at least open; that it was so meant by its promoters, and that he limself so understood it. At any rate we seem warranted in adding the name of Dr. Gunning to those among the reviscrs of 1661 , who could not have intended by what they were doing to exclude from the English Church all belief in a Real and Substantial Presence.

$\S 15$. It is plain that any passages bearing on the ques. tion of Adoration, either in the Liturgy itself, or in the other portions of the Prayer-book, or in the Articles or Homilies, were intended to be read by the light of this protestation, the latest authoritative statement of the Church of England on the subject. In the revised Liturgy, for example, significant changes were made, (as all men know,) at least in four important portions of the Office. First, in the preliminary exhortation, the words of King Edward's second Praycr-book, copied in that of Elizabeth, are, "He hath given His Son our Saviour Jesus Christ, not only to die for us, but also to be our spiritual food and sustenance, as it is declared unto us, as well by God's Word as by the holy Sacraments of His blessed Body and Blood." In 1662 this was altered to the present form, "To be our spiritual food and sustenance in that holy Sacrament." The change from "by" to "in," and the omission of the saying about God's Word, introduce an obvious and important meaning: the same, no doubt, with the corresponding clause in the first Praver-book of King Edward, - " hath not only given His body to death, and hath shed His blood, but also doth vouchsafe, in a Sacrament or Mystery, to give us His said Body and Blood to feed upon spiritually."

There is, secondly, the direction to the priest himself to set the Bread and Wine on the altar-table, under the name of oblations, with a petition for their acceptance.

Thirdly, the rubric for celebration adds or restores the following particulars:- that the prayer is called the Prayer of Consecration; that the priest is to stand before the table; that he is to break the Bread and take the Cup into his hands before the people, doing the acts, as well as saying the words, with which our Lord consecrated at first. These were all changes in the same direction with that very sig- 
nificant one made in Elizabeth's time,--the restoration of the Cinar. IV. words, "the Body and Blood of our Lord Jesus Christ," to the form of distribution. So much the less probable would it appear, that in adopting King Edward's rubric, which Elizabeth had ignored, the revisers meant to damage the doctrine of a Real and Essential Presence; so much the more are we encouraged to believe that they drew the distinction which we contend for, between "Corporal" and "Essential," and intended to express it by the way in which they modified the statement.

Fourthly, in the Post-Communion, (what, on reflection, appears very significant,) our present Liturgy is the only English one which provides for the covering of the consecrated Bread and Wine, if any be left, with a fair linen cloth, and for the reverent eating and drinking of it by the priest and some of the communicants: correcting what was most probably an oversight in the last rubric of Queen Elizabeth's Liturgy, which says simply, "If any of the Bread and Wine remain, the priest may have it to his own use;" making, in worls, no difference between consecrated and unconsecrated.

These details, taking them one with another, are such as not simply to add decency to the celebration, but likewise to recall and bring out the ideas of a real Sacrifice and a real Presence, before (in the judgment of the revisers) too much obscured. And those are not ideas to be forgotten or put aside, when the person impressed with them kneels to receive the Sacrament. If he believe and consider, he cannot choose but adore.

\$16. And now, what was said before of the Scriptural argument may with some reason, perhaps, be repeated here; that some very distinet and positive prohibition ought to be produced from some document of equal authority with the Prayer-book, before the worship of the Inward Part of the Lucharist can be pronounced unlawful in the Church of England. Such prohibition is supposed to be found in the Articles; and the supposition, as all men know, has lately received countenanee from high authority. It has been ruled that the doctrine contained in this saying, namely, "Wor- 
Crap. IV. ship is due to the real though invisible and supernatural Presence of the Body and Blood of Christ in the holy Eucharist under the form of Bread and Wine," is "directly contrary and repugnant to the twenty-eighth and twenty-ninth Articles of Religiony."

Greatly indeed it were to be wished, for many obvious reasons, that the particular words of the Article, or Articles, to which the document alludes, had been specified, either in the sentence itself, or if that course would have been informal, in the judgment which preceded it. In default of such specification, one can only surmise that the sentence proceeds either (1.) upon the last clause of Art. XXVIII.; or (2.) upon some doctrine supposed to be implied in the two Articles taken as a whole.

The last clause of Art. XXVIII. is, "The Sacrament of the Lord's Supper was not by Christ's ordinance reserved, carried about, lifted up, or worshipped." This being the only place in the Articles where Eucharistical Adoration is mentioned, it seems natural to look to it for an explanation of the sentence. Yet many perhaps may feel hesitation in doing so: the premiss will appcar to them so palpably unable to support the conclusion, that they will cast about in their mind for some other ground on which the judges must have proceeded.

For what, after all, does this proposition amount to, "The Sacrament was not by Christ's ordinance worshipped ?" Take it in its logical form; it is not so much as a censure on the practice. It need not mean more than that the outward adoration was no necessary part of our Lord's institution.

Let us put a case connected with the holy Eucharist. Suppose (since we know that very sad and hurtful controversies have arisen on the point) that some Eastern Council, wishing to allay disputes, had passed a canon in these terms, "The Sacrament of the Lord's Supper was not by Christ's ordinance consecrated in leavened bread :" could we justly understand more than this; that whereas a notion had prevailed, and been fiercely maintained, that the leaven was a

$y$ Proceedings in Archdeacon Denison's Case, pp. 134, 5. 
necessary part of the ordinance, it should not hereafter be Crap. IV. insisted on, nor those Christians censured as departing from Christ's institution, who, as in the West, thought it suitable to "put away" the leaven? Would not the clause, so worded, have still left it open to Easterns, continuing to think leaven more agreeable to the institution of Christ, to go on using leaven, and arguing for it as the more dutiful way? There might be many reasons for it, though it werc no necessary part of Christ's ordinance; and so, for anything that appears to the contrary in the wording of this clause, there might be powerful rcasons for the very adoration of the Eucharist, and an English clergyman might be free to allege those reasons.

$\S 17$. This argument gains in strength, if we go on to consider the other practices enumerated here to be forbidden along with adoration. They are Reservation, carrying in Procession, and Elevation. As far as the wording of the sentence goes, those three usages are equally forbidden with the worship of the Sacrament, and deprivation would be alike ineurred by pleading for or inculcating either one of the four. Yet it is notorious that reservation had been practised from the beginning in the ancient Church, for the benefit, at least, of the sick and persecuted: Justin Martyr z saying, "To those who are not present the consecrated gifts are sent by the deacons ;" and Irenæus ${ }^{2}$ testifying that in the time of Anicetus, i. e. the middle of the second century, the Eucharist used to be sent as a pledge of Communion from one diocese to another.

Further : reservation had only just ceased to be part of the reformed English Ritual; for until 1552 the Communion of the Sick was thus ordered: On days of publie celebration, the priest "shall reserve so mueh of the Sacrament of the Body and Blood as shall serve the sick person, and as many as shall communicate with him, (if there be any); and so soon as he eonveniently may after the open Communion, shall go to administer the same ${ }^{\mathrm{b}}$."

Now we may well understand that there might be abuses

21 Apol. $\$ 65$.

ap. ad Victor. ap. Euseb. Eccl. Hist. v. 21.

b Two Liturgies, 1. 368 . 
Cнар. IV. and superstitious practices, which might entirely justify the Chureh, or any portion of it, in suspending or abrogating such an usage; and that, in order to reconcile men's minds to the change, it might be needful to point out that reservation was no part of Christ's institution. But supposing a elergyman to think and argue, on grounds devotional, doctrinal, or practical, that it was our duty to restore the praetice; so long as he refrained from holding that it was part of Christ's institution, would any one say that the clergyman was holding doctrine contrary or repugnant to the Article?

Now if this hold in respect of the reservation, why not in respect of the worship also? If Bishop Ridley (e. g.) were now living, and were to write and preach what he maintained almost with his last breath on this subject, -

"We hold with the eyes of faith Him present after grace, and spiritually set upon the table; and we worship Him that sitteth above, and is worshipped of Angels... We adore and worship Christ in the Eucharist; and, if you mean the external Sacrament, I say that also is to be worshipped as a Sacrament c;" -

we might demur to his eoncluding affirmation as likely to be offensive; but since he neither affirms nor implies anything here concerning Christ's ordinance, how could we say with show of reason that he was eontradicting this proposition, "The Sacrament was not by Christ's ordinance worshipped?"

$\S 18$. So much would be true, as touehing Art. XXVIII., were a person even to maintain the worship of the whole Sacrament, or of the outward part. But now the proposition which has been condemned formally excludes both these from worship, and limits itself to the Inward Part alone. Thus it runs :

"It is not true that the consecrated Bread and Wine are changed in their natural substances, for they remain in their very natural substances, and therefore may not be adored. It is true that worship is due to the real though invisible and supernatural presence of the Body and Blood of Christ in the Holy Eucharist, under the form of Bread and Wined."

Be it well noted that this latter phrase is a description

c Proccedings, \&c. at Bath, p. 94.

d Ibid. p. 226. 
of the Inward Part or thing signified in the Sacrament, as Cнар. IV. "Bread and Wine which the Lord hath commanded to be received," is of the outward part or sign_-" the outward visible sign or form"- with which the Inward Part is sacramentally connected: that connection being signified, as is usual in language, by the preposition 'under.' Now propositions, to be contrary to one another, must have substantially the same subject and predicate. Is this the case here? The subjeet of the condemned proposition-(I change the wording for reverence' sake, but the two expressions are meant to be, and I believe are, equivalent;)-the subject, I say, of the condemned proposition is " the Inward Part or thing signified in the Lord's Supper." What is the subjeet of the proposition in the Article? "The Sacrament of the Lord's Supper." Can this possibly mean "the inward part or thing signified only?"

The word 'Sacrament,' as every one knows, has a looser and a stricter use. In its stricter use, as defined in the Catechism, it means both the outward and inward parts. In that sense the proposition condemned, limiting itself as it does to the inward part only, cannot contradict the proposition in the Article, for it speaks of a different subject. If we take the wider meaning of 'Sacrament,' whereby it is taken for Sacre rei signum, any divinely intended sign of something pertaining to God, then the "Sacrament of the Lord's Supper" must mean the outward part, not the inward-the Bread and Wine, not the Body and Blood of Christ: for These are not the sign, but the thing signified. In neither acceptation, then, can the word Sacrament mean the Inward Part in the Eucharist exclusively ; and yet, unless you give it that meaning, there is plainly no repugnanee nor contrariety between the condemned proposition and the proposition in the Article.

That the proposition in the Article refers not to the inward part, was distinetly stated (if the report be correet) by the counsel for the promoters of the last sentence :

"The Article closes with this statement:- 'The Sacrament of the Lord's Supper was not by Christ's ordinance reserved, carried about, lifted up, or worshipped,' which showed the distinction that 
Cuap.IV. was made between the outward and visible sign, and the inward and spiritual grace. They could not reserve the spiritual grace, they could not carry that about, they could not lift it up,-it was of a spiritual nature. Therefore, again he contended that it shewed this Article used the words 'Sacrament of the Lord's Supper' in a senso which confined it to the outward and visible sign, to that which they could see-to that which they could handle e."

Is not this expressly maintaining that the worship of the outward part is the only worship forbidden (if it be forbidden) in that Article? and is it not prima facie surprising that on such premises a condemnation should have passed, not only on Mr. Denison but on Bishop Andrewes, whose words were declared by a principal person in the court to be "a reiteration" of what had been said before? those words being, "Christ Himself, the Thing signified of the Sacrament, in and with the Sacrament, is to be worshipped."

As to the predicates of the two propositions-that in the Article, and that which has incurred condemnation-they have been already shewn not to be identical, unless it be the same thing to say that a thing ought to be done, and that it is formally ordained by our Lord.

$\S 19$. All things considered, there seems much reason to fear that the sentence proceeded not so much on the final clause of Art. XXVIII. as on a certain construction of that and the following Article taken together, making out not only Transubstantiation, but any Real Objective Presence to be virtually denied in them. This, granting the construction, would make the proceeding logical,-a thing too hard for human skill, if their sole allegation were the saying in the twenty-eighth Article. But what was gained in logic would be lost in candour and frankness,- to say nothing just now of sound theology.

For the question of the Real Objective Presence was raised in the Articles exhibited to the Archbishop at Bath ${ }^{\mathrm{f}}$, and that doctrine was not treated argumentatively, but assumed to be an error, in the pleadings of the promoter's advocate; afterwards, the defendant's reply having been heard, the point of 
the Real Presence, and also that of its depending upon con- Cris. IV. secration, were withdrawng. If, after all this, the conviction on the matter of adoration went upon the ground that the Real Presence after consecration is an error condemned by the Articles, it surely ought to have been so declared by the court, in Christian and fatherly charity to souls which were sure to be perplexed and offended; if not in plain and simple justice to persons amenable to the law, and naturally anxious to know what their own legal position is.

But now, supposing for a moment-what, under these circumstances, can hardly be supposed-that the adoration was condemned simply because it was felt to imply the Real Presence, still the condemnation professes to ground itself on these two Articles; and therefore it seems requisite for the completeness of this argument to shew that those Articles, taken by themselves, do in no wise negative the idea of such a Presence as is alleged. And this may be very quickly done.

In the twenty-eighth Article, the first paragraph states "that to such as rightly, worthily, and with faith receive the same," i. e. the Sacrament, "the Bread which we break is a partaking of the Body of Christ; and likewise the Cup of blessing is a partaking of the Blood of Christ." Now take the literal and grammatical meaning of this, (for I presume it will hardly be contended that an accuser may travel out of that meaning, while a defender is so strictly confined to it): what is there in the saying that "the Bread is a partaking of Christ's Body," inconsistent, literally and grammatically, with the saying that the Body is really present? The first may not warrant the second; but is there any contradiction? Surely, of the two, there is something more like a contradiction in denying the Presence of that which is affirmed to be partaken of.

The Article proceeds to deny Transubstantiation: but to say that this is denying the Real Presence, is just begging the question. Certainly the objections here taken to Transubstantiation do not apply to the notion that the inward and outward parts are both equally present. That notion,

B Proceclings, \&c. at Bath, pp. 69, 70, 72-74, 125. 
Cндг. IV. taken according to the letter, is proveable from Scripture. It maintains the "nature of a Sacrament," making both parts real. Nor does it appear from history to have been the "occasion of many superstitions."

"The Body of Christ is given, taken, and eaten, in the Supper, only after an heavenly and spiritual manner." In this all theologians agree; it proves, therefore, nothing against any particular section of them. The words "given" and "taken," as has been often observed, would appear, as far as they go, to imply, rather than disavow, the Objective Presence ${ }^{h}$.

But the sentence in the Article chiefly relied on by those who shrink from the letter of Scripture, is the following: "The mean whereby the Body of Christ is received and eaten in the Supper is faith." Yet, on a little consideration, one might perhaps not unreasonably ask, how a person believing the Real Presence of both parts in the Sacrament, could more accurately express his belief in the manner of receiving the Inward Part, than by adopting this very sentence? The point will be clearer if we supply what there was no need for the Article to mention - the manner of receiving the outward part. "As the mean whereby the Bread is received and eaten is the mouth, so the mean whereby the Body of Christ is received and eaten in the Supper is faith." What shadow of denial of the Real Presence is here?

Besides, we ought to know what the word "faith" means in this sentence. Does it denote the general qualification for worthy receiving, - that "lively faith" which is mentioned in the following Article?-or does not the tenor of the sentence rather lead us to think of a special act of faith in the reality and blessedness of that which is being received? even as it is required of persons to be baptized, to have "Faith whereby they stedfastly believe the promises of God made to them in that Sacrament." And the corresponding phrases in S. Augustine, so often quoted in this argument,

- Compare the letter of Bishop Guest, who penned the Artiele, to Lord Burleigh; ap. Pusey on "The Real J'resenee," p. 203. "I told him [13ishop Cheney] plainly, that this word 'only' did not exelucle the Presence of Christ's Body from the Sacrament, but only the grossness and sensibleness in the receiving thereof." 
import as much: "This is the work of God, that ye believe CHar. IV. on Him whom He hath sent. This, then, is to eat, not that meat which perisheth, but that which remaineth to eternal life. Why make ready the teeth and belly? Believe, and thou hast eateni." As if our Lord should say to them, "In that of which I am speaking to you, the eating of that lifegiving meat," (which, as it appears afterwards, is the Inward Part of the Lord's Supper, "your work, or rather Gol's work in yon, is simply to believe: He will take care of the rest. Bodily eating is for this ordinary Bread; as for the Bread which cometh down from heaven, 'believe, and thou hast eaten.' "In these and the like passages, it is clear that beneficial receiving alone is spoken of, and that the proper instrument by which men so receive is their faith in Him so giving Himself to them. 'There is not the smallest appearance of S. Augustine's sympathizing with those among the Reformers who regarded the participation of the Redeemer's Body and Blood as ordinarily separable from the grace of the Eucharist, any more than there is any instance in Holy Scripture of such eating and drinking being spoken of except in connection with that Sacrament. And next to Holy Scripture, S. Augustine is plainly the authority most deferred to in the Articles on this subject. We are not, therefore, likely to be far wrong if we take the twenty-eighth Article as insisting, not on faith in gencral, but on faith in the particular grace of the Sacrament. "Believe that thou receivest Him," (so we scem to be told,) "and thou hast Himj."

Concerning the twenty-ninth Article: the safest way is to understand it as interpreting S. John in the same sense as S. Augustine does, whom it quatcs ${ }^{k}$. But if we took it, as the Judgment does, to deny all cating, in any sense, of the Iloliest Thing by the wicked and unworthy, not even so could it be inferred that the framers of that Article shrank from the doctrine of a Real Objective Presence in respect of the good and faithful: nor does the Article, so under$\mathrm{s}^{+}$ood, contradict the notion which has commended itself to

1 In Joan. Wv. tr.xxv.12: ef.xxvi.12.

j Cf. S. Mark xi. 24. k What that sense is, 1)r. Pusey and Mr. Grueber have shewn. 
Crap.IV. some, that there is at first a Real Presence to all, but that it is withdrawn when the unbeliever communicates.

Are we not, on the whole, justified in inferring that the Real Objective Presence is not impugned by the general tenor of these two Articles? Therefore, neither is adoration impugned as implying the Real Objective Presence.

$\S 20$. 'The question then comes back upon us, What could have been the Censors' ground for saying that it is impugned? May it be pardonable, if onc venture to suggest that even good and sensible men, giving way to a panic, are not likely to be good reasoners; that something like this happened to the authors of this sentence; that they hastily caught up, as people do in a panic, that which in fact is a weapon from the Roman armoury, viz. that the Article docs in such sense deny any reception by the wicked, as virtually to deny the Real Objective Presence also; and then knowing that adoration at least of the heart is inseparable from belief in such Presence, they considered it as condemned by the two Articles taken together? Whether this, however, or any other, was the process by which they arrived at their conclusion, it is impossible not to feel deep regret that it was not distinctly stated, according to the ordinary practice of ecclesiastical as well as civil courts in this country, more especially in cases involving heavy penalties. And in this case, the court being eminently, by its composition, a court Christian, it would not perhaps have been irrelevant or unfatherly, had some words been spoken to relieve the consciences of the many, who have hitherto practised unquestioning adoration, without a thought of being undutiful to the Church; and to protect them from the troublesome scruples and bewildering imaginations, doctrinal, metaphysical, or ecclesiastical, which the bare authoritative utterance of such a sentence would be likely to awaken in them; and that at a time when their hearts most earnestly long to surrender themselves to their Saviour without reserve or interruption.

$\S 21$. Or, it may be, the condemnation was meant to apply not so much to the requirement of worship, as to the phrase by which the Object of worship had been defined,-- "the Body 
and Blood of Christ under the form of Bread and Wine." Crap, IV. But if so, then, according to a rule which has entered largely into this very judgment, it was specially incumbent upon the Censors to make known the grounds of their censure. In denying the Body and Blood of our Lord Jesus Christ to be eaten by the wicker, they have laid great stress-indeed, the main stress of their cause-on the title of Art. XXIX. They have refused, it would appear, to consider the explanation which has been offered, and sustained by a large array of authoritics, to the effect that the phrase, "eat Christ's Body," is a theological phrase capable of more than one interpretation; that is, that it has more than one "literal and grammatical scnse," and that the body of the Article itsclf fixes the title to that meaning which would justify the defendant. All this they entirely ignored, and grounded a sentence of deprivation on a statement, of which all that could be fairly said was, that it was contrary to one of two literal and grammatical interpretations of one single phrase. By this, at any rate, they would seem to bind themselves to be very "literal and grammatical" in all their proceedings, and not to condemn the other expression, "present under the form of Bread and Wine," (which is, in other words, "really and objectively present, as the inward part of the Sacrament,") unless they could shew some "literal and grammatical" contradiction of it in the Articles. I do not see how this can be denied, without maintaining one rule for the prosecution and another for the defence. No such contradiction has yet been distinctly alleged. If any exist, the learned assessors will be only doing themselves justice in pointing it ont.

$\S 22$. And more than this. There is among the Thirtynine Articles one which was originally specified in the charge against Archdeacon Denison, but the mention of it was afterwards, for whatever reason, withdrawn; I mean the thirtyfifth, which re-asserts the general doctrine of the Book of Homilies. Now the condemned phrase ("under the form of Bread and Wine") is taken, as every one knows, from the Book of Homilies; not, indeed, from the body of any homily, but from one of two authorized titles of the fifteenth homily of the second book,- - authorized, undoubtedly, one as much as the other; and therefore, according to all common rulcs 


\section{It does not imply the Errors disavowed by our Church;}

Chap. IV. of construction, the second to be taken as at least reconcileable with the first; which notion is further confirmed by the description prefixed to the body of Queen Elizabeth's Homilies: "The second part of Homilies, on such matters as were promised and entituled in the former part of Homilies."

And on comparing the two titles, few persons, I think, would doubt that the one was meant to be equivalent to the other. The first is "the due receiving of the Body and Blood of Christ under the form of Bread and Wine;" the second, "the worthy receiving and reverent esteeming of the Sacrament of the Body and Blood of Christ." "The Body and Blood of Christ under the form of Bread and Wine" is thus set before us as something inseparable from "the Sacrament of the Body and Blood of Christ," - as, indeed, it must be, according to the account of a sacrament in the Catechism.

And surely this-being part of the definition of the Eucharist-is a main point of Christian doctrine. If it be so wrong, so ungodly and unwholesome, as this condemuation supposes it, how can it be true that the Homilies, taken generally, "contain a godly and wholesome doctrine?"

One way, indeed, is conceivable, in which we might be foreed to admit the hypothesis of the phrase having been left by mistake; i.e. if the homily so eutitled contained any statement clearly repugnant to the first title. But no such statement ever has, or can be, produced from this or any other homily.

No doubt the formula, "Sub specie Panis et Vini," is used by the Roman Catholics; but it is also used by the Lutherans, and from them, probably, it was adopted by Ridley, whose sentiments on Christ's Presence in the Eucharist are known to have differed materially from Calvin's '. They were formed, confessedly, on "The Book of Bertram the Priest," who describes the holy Sacrament thus: "Sub velamento corporei Panis, corporeique Vini, spirituale Corpus, spiritualisque Sanguis existit m." "Sub relamento:" the phrase is equivalent to "under the form." That Bertram meant by it to express a spiritual, not a carnal or material, Presence, is plain by his saying, "Panis ille vinumque figurate Christi Corpus et Sanguis existit ${ }^{m}$;" and, "Secundum visibilem creaturam corpus

\footnotetext{
1 See Remains of A. Knox, ii. 161, 166. 'm Book of Bertram, p. 24, ed. 1686.
} 
pascunt, juxta vero potentioris virtutem substantiæ mentes Crap. IV. fidelium et pascunt et sanctificant." That he did not receive Transubstantiation is also plain; for his words are, "Secundum creaturarum substantiam, quod fuerunt ante consecrationem, hoe et postea consistunt." Bertram, therefore, holding Christ's presence under the form of Bread and Wine, did yet contradict the same two errors which the Reformed Church of England warns her children against.

And however coarsely Luther himsclf, and some of the Lutherans, might sometimes express themselves, there ean be no reasonable doubt that the very same is the true meaning of the Confession of Augsburgh, teaching (Art. X.) that "with the Bread and Wine, the Body and Blood are truly present in the Lord's Supper, and truly given to those who cat there; and they censure such as teach otherwise."

Neither Ridley, then, nor the Homilies, nor such as adopt their language, can fairly be eharged with holding the gross, carnal idea which was afterwards imputed to them under the name of Consubstantiation: which idea secms to be censured by implication in our twenty-eighth Article, where the Body of Christ is said to be "given, taken, and reeeived in the Supper, only after a heavenly and spiritual manner;" and at the end of the Liturgy, where we disclaim adoration of any corporal Presence of Christ. Well may we, with the whole Church rightly understood, eondemn and disavow any notion of such a Presence. But to condemn the phrase, "under the form of Bread and Wine," would be condemning, first, Bishop Ridley, and the rest who sanctioned the First Book of Homilics, and, through them, the Confession of Augsburgh, and the whole body of orthodox Lutherans.

Not in this present instance only has mischief been done by a vague dread of Consubstantiation, hurrying people on to erroneous censures, which would have been spared, had they given themselves more time to consider either the true meaning of the words censured, or the cxtent to which the censure would reach.

$\S 23$. Thus, in default of all explanation from those who decided the other day that Eucharistical worship is contrary to the Articles, endeavour has been made to trace, as ex- 
CHAr. IV. actly as one might by conjecture, the possible ground of that decision, and to shew that it is as little warranted by the Prayer-book, Articles, and Homilies, as by Holy Scripture and Primitive Antiquity. The survey, such as it is, will perhaps have sufficiently cxplained the deep and intense anxiety which was felt by many, at the first promulgation of the sentence, for the integrity of the Catholic doctrine of the Holy Eucharist,-an anxiety which must continue to be felt, until it shall please God to put in the hearts of those who have spiritual authority, either to withdraw that condemnation, or so to limit it that it shall not seem to contradict the Real Objective Presence.

For assuredly it is not, as it now stands, a mere question of posture. Were that all, there is not one who denies the full right of every particular or national Church to choose among the several postures of adoration, and to forbid the use of either or all of them on this or that particular occasion, when it might cause scandal or confusion; just as English Churchmen are left, as it seems, to their own charity and discretion, whether or no to recognise by outward gesture the Presence which they must beliere (unless they deny altogether the validity of the Roman Sacraments) when they meet with any of the customary solemn processions, or on other occasions not unfamiliar to travellers.

The question, it must be repeated, is not "how or when we are to adore," but "whether it is lawful at all to adore Christ as the Inward Part of the Sacrament?" That this is the real issue we were officially told by the Archbishop's principal lay assessor, when he pronounced a certain sentence quoted from Bishop Audrewes to be a " reiteration" of what had been condemned before: and neither his Grace himself, nor any of his clerical assessors, did either then or at any time since intimatc any dissent from the statement.

Therefore, but for a providential flaw in the form of proceeding, it would stand at present before the world as the judicial sentence of the Archbishop of Canterbury, that it is contrary to the Articles to say, "Christ Himself, the Thing signified of the Sacrament, is to be worshipped in and with 
the Sacrament;" and that any beneficed person so teaching Спıр. V. and worshipping must incur deprivation. Now of course no one supposes that the Archbishop and the clergy sitting with him would deny that Christ is to be worshipped, and with special worship where He is especially present. It remains, therefore, that they meant to deny any such especial Presence in the Eucharist as should claim special worship and homage; and what is that but denying altogether any Real Presence after consecration? Consequently, believers in that Presence-not only in its truth, but in its essential importance-must apprehend a vital doctrine of the Gospel to have been put in jeopardy by this decision. It is a sad thing to say, but is it not too true?

\section{CHAPTER V.}

DUTIES OF CHURCHMEN IN RESPECT OF THIS CASE.

$\S 1$. THERE remains the very serious practical inquiry, how the position of persons so believing within the Church of England was or is affected by these proceedings. I call it a "practical" inquiry, because, although that particular" case is at an end, the points involved in it may at any time be mooted in some other instance: and in the present unhappy state of parties, are too likely to be so. It is, indeed, two questions in one; for it may be taken as relating cither to our legal or to our moral and spiritual position. With regard to the former, it is useless now to speculate. We can but leave it to receive solution, if need be, from the proper authorities in due course of law. But should it again arise, and be finally decided as it was the other day in the Court of Arches, then (as the judgment on appeal will be legally binding at least on the diocesan courts of England,) the other question will arise, How shall we stand, morally and spiritually, as clergymen bound by certain Articles, when the legal interpreters of those Articles have declared them to be, by implication, contrary and repugnant to a tenet which we hold as a vital doctrine of the Gospel?

$\S 2$. But before going on to this, it may be worth while to 
Crup. V. say one word more on the comparatively immaterial question of our legal position. Speaking under correction, I believe that, as a matter of course, until the legislature decree otherwise, the decision of the lighest court of appeal rules all subsequent decisions. Therefore every elergyman from that day forward will understand, that if he be known in any way to hold the duty of worshipping Christ, "in and with the Sacrament, as the 'Thing signified of the Sacrament," his place and bencfice in the Church of England will be at the mercy of any one choosing to cxhibit articles against him. And since it is known that there is a numerous and powerful, and in these matters (may we not say it?) an unscrupulous section of the Church, watching to see whom they may take at such an advantage; there can be small doubt, humanly speaking, what will become in a few generations, not only of the custom of adoration, but of the doctrine inseparable from it-the doctrine of the Real Prescnce among us.

Again; it is doubtless true that legally the act of Elizabeth, under which the judgment has been obtained, would not, taken by itself, constitute the Articles the sole test of doctrine. But those who have expressed a fear of such a result were thinking not of that act only, but of its effect taken conjointly with the Gorham decision. The latter scemed to rule that nothing should be held obligatory, unless it were affirmed in the Articles. The former, that nothing, however plainly affirmed in Holy Scripture, or the Prayer-book, should be so much as allowed, if it appeared at first sight contrary to the Articles; assuming thereby that that one document had nothing in it ambiguous, nothing equivocal, nothing which could need to be interpreted by comparison with other documents of co-ordinate authority. What more could be desired by any one who might wish to escape from Holy Scripture and the Prayer-book, and make the Thirty-nine Articles our sole standard? If a man were minded, for instance, to deny the Inspiration of Scripture, the Eternity of hell-torments, or the personal existence of the Evil Spirit, he would have only to point out that they are not affirmed in the Articles. If he wished to deny S. James's doctrine of Justification by works, or to enforce 
Calvin's doctrine of absolute Predestination, he might have Chар. V. his way by quoting the letter of the elerenth and seventeenth Articles.

If it be really the mind of the present English Chureh so matcrially to narrow her pale of admissible doctrine on one side, and enlarge it on the other; would it not be wiser, better, more seemly, to do it once for all, deliberately, and in the face of day, that all men might know what themselves and others are about, rather than go on in this unhappy, vexatious course; watching for seasons when an adversary happens to be unwary or unpopular, or when sympathy may be hoped for from a prime minister or a judge; and disposing of deep and high points of theology by a side-wind,

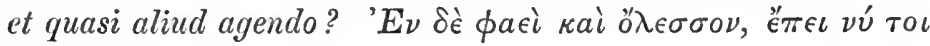
$\epsilon$

\$3. But be that as it may, the question will remain for individuals, supposing the sentence confirmed, What ought they to do, who have gone on hitherto believing the Real Presence, and adoring accordingly, in no undutifulness to the English Church, but in full convietion that they were but earrying out what they had learned in the Catcchism and Communion Office? They cannot gire up their convictions, they cannot ccase to believe and adore, in deference to a mere affirmation, even from the highest human authority, the reasons (for whatever cause) being withlield; nor yet upon such reasons as have hitherto been alleged. Neither is the matter an abstract one, such as one may withdraw his mind from, and exclude it from his teaching, or even in a way suspend his belief of it, in a dutiful wish to obcy those whom God's providence has set over him. Such cases are conceivable; perhaps (e. g.) a person's view of predestination may admit of being so treated; but whether or no Jesus Christ the Son of Man is specially present in the Holy Sacrament, as the Inward Part thereof, and whether to worship Him accordingly or no,-these are thoughts which cannot be put by; they eome before the mind and heart as often as you go to His altar. And if you believe them to be essential parts of Christian truth and duty, you must teach them to all entrusted to your carc. 
Crap. v. The only question will be, Is a person continuing so to believe and teach bound to resign any privileges which he may enjoy in virtue of his subscription to the Articles? or is he free in conscience to retain them as long as he can, if he consider it otherwise his duty to do so?

Now this question seems to resolve itself into another and a more general inquiry. It being allowed that liuman laws bind the conscience of the subject to obey them according to the intention of the legislature, if not contrary to the law of God; we are to consider whether the like submission is absolutely due to the judicial interpretations of the same laws? For example: certain goods of foreign manufacture are, or were lately, prohibited in this country, and no doubt it was a moral duty to abstain from importing what were unquestionably known to be goods of that description; but let us suppose that in a particular instance a question had arisen, whether such and such a fabric came under that description, and the judges had determined it in the affirmative, while the merchant, from his technical knowledge, was thoroughly convinced of the negative; was he bound in conscience to abstain from importing the like in time to come? or might he innocently risk the transaction if he thought it worth while? Other imaginary cases might be put, but this one will be sufficient to explain what is meant.

Now, as I can hardly conceive any one imagining that the tradesman in this instance was morally guilty of breaking the law, so neither, or rather much less, would the same guilt secm to attach to a clergyman retaining his cure, if he could, after his opinions and teaching liad been condemned, supposing him sincerely and seriously convinced before God that the condemnation proceeded on a mistake in the law. It would be a question, not of right or wrong, but of expedient or inexpedient; and surely, in the event we are now contemplating, (may God avert it! but if it should happen,) trutlı and charity, and loyalty and devotion, the honour of God Incarnate, and the salvation of the souls of our brethren-all the motives that can be imagined going to make up the highest expediency-would render it the duty of every Catholic clergyman to abide in his place until he was forcibly ex- 
pelled from it, either by a like prosecution, ending in like CuAp V. manner, or from inability to bear up against the worry and expense of the proceeding.

If any misgiving occurred to a right-minded person in adopting this course, it would probably be on the ground that there was some appearance of breach of trust, in respect of those under whose authority he was taking the benefit of his subscription, conscious all the while that he was subscribing in a different sense from what they might be willing to allow. But this scruple might at once be met, by taking care to give sufficient notice of your mind and purpose to the persons concerned, and so enabling them, if they thought proper, to put you also on your trial ${ }^{\text {n. }}$.

$\S 4$. So much may suffice with respect to our legal diffculties : but there are others more serious, connected with our ecclesiastical position. We know too well, by very sad experience, that some earnest persons regard the Church of England as distinctly committed by the sentences of that which may happen practically at a given time to be her supreme Court of Appeal. So that if the late judgment against adoration (e. g.) had been unhappily affirmed by her Majesty in Council, there would have been, according to them, no help for it: the Church by law established would have denied the faith, and belicvers must have sought another home where they might.

Now many will feel as if this saying refuted itself by its very extravagance. To suppose that for one sentencc, once promulgated and enacted, by a court constituted as that of which we are speaking, every one's faith and practice remaining just what it was before, by far the greater number of our communicants knowing nothing at all of the matter, not even aware that there was any trial going on, and ready, for aught any one can tell, to disclaim the doctrine implied in the sentence, if it were duly explained to them, from the very bottom of their hearts;--to suppose, I say, that by onc such decision all thesc believing multitudes were fairly turned out of God's Church on earth, and left with the heathen to the forlorn hope of incurable ignorance,-all this would be in-

"See note at the conclusion. 
Cндр. V. tolerable, nay, impossible, unless some unquestionable word of some infallible authority wore shewn for it. Compare it with the known dealings of the Almighty towards either Churches or individuals. See how it looks when judged of by the analogy of the faith. No doubt there are fearful instances of one person falling in a moment, and drawing after him in ruin thousands, themselves at the time unconscious, or not yet existing. We do not forget Adam in Paradisc, nor Esan selling his own and his children's birthright, nor Saul when Samuel turned away from him, nor Jeroboam when he made Israel to sin; nor the several ringleaders of heresy and schism among Christians, and how their unhappy followcrs were cast out with them; nor (in a word) how the fathers' sins are by the Divine law visited on the children: and it is, of course, possible that any particular instance of transgression and misleading may prove to be one more in that list; but who at the time shall declare it so? Surely none may do that with authority but the Judge Himself; and when He has done so, He has eonstantly done it by signs unequivoeal-miracles or prophecies, or the consenting voice of His Chureh; and even then not until after long endurance and repeated warnings. But for private Christians to take upon themselves to pass that sentence,-which a man would in effect be passing, if he forsook the Church's communion for any such proceeding as is now dreaded,-this would seem not unlike the error of those who were warned that they knew not what manner of spirit they were of. One mortal sin, we know, deliberately consented to, is cnough to destroy a soul; but we know also how long and how tenderly He whose name is Merciful as well as Jealous has borne with whole years of transgression and has not destroyed; we know that His merey is over all His works; that it extends to the thousandth generation, while He is said to visit iniquity upon children only and children's children. The antecedent probability therefore is, in every case, until the Cliurch has examined and ruled it, that the error complained of, howerer real and deadly in itself, does not bring such a taint of heresy over those communicating with its professors, as to separate them, ipso facto, from the Church. 
\$5. Secondly, in this particular case, the crror coming Carap. V. out not in the shape of a synodical or legislative enactment, but of a judicial decision; as it is no part of the law of the land, of force to bind the conscience of the subjects, so is it no part of the law of the Church, (the provincial Church, of course, I mean,) with power to bind the conscience of its members. It betrays, indeed, a sad want of diseipline, and threatens and forebodes an eventual corruption of doctrine; but it leaves the formularies of the Church and the faith of its present members just where they were. If any one doubt this, let him consider one or two parallel cases. Suppose, from some epidemical delusion, (we have seen such things at no great distance,) it had become morally impossible to obtain a verdict of guilty against a murderer in a particular country-would any one think of laying it to the charge of that country that it had no law against murder? Or what if, at any time, by connivance, corruption, or indolence, it should appear that the slave-trade is still being carried on in English vessels, or slavery practised in some English colony-would it be fair to say that slavery and the slavetrade had again become part of the laws and institutions of England? Or again,-to put a case nearer the actual one,if we imagine the days of Arian ascendancy returned, and, by some such combination as we read of under Constantius, a judicial body formed which had a leaning that way, and skill more or less to carry with it the popular feeling, and thus a sentenee obtained against orthodoxy : would such a decision, or a liundred such, prove the English Church to be in its essence really Arian? They would certainly cause great anxiety lest it should quickly become such; but instead of their affording any excuse or reason for separation, every heart that was truly loyal to our Saviour would assuredly feel called on to cling to its profession the more earnestly, and take away the reproach from Isiael; and if any made that state of things an argument for withdrawing himself and joining some other Christian body, how very sure should we feel that he was either indulging temper, or but availing himself of the first cxcuse lie could find for carrying into effect what for other reasons he had before determined on! 
Chap. V. The matter may be put in this light. Casuists arc agreed that the proper authorities to determine the meaning of documents subscribed to, are the same by whom the subscription is enforced; i. e., in this case, the Church and State of England. There can be no reasonable doubt that when these bodies last legislated on the subject, in 1661, they meant to reccive subscriptions in the sense now condemned. If they have changed their mind and will, let them declare it in the only way in which it is competent for them to do so; namely, by fresh legislation corrective of the former. Until they shall have so done, they must be taken to be of the same mind as before, and the old interpretation to stand good. Any court of justice interpreting the document on any other principle narrower than this, must be presumed to be mistaken, and cannot bind the conscience by its decision. Nothing can do that, short of the voice of the legislature, distinctly enacting the new interpretation. The synod or convocation so decreeing may bind us as Churchmen; the parliament as Englishmen; until they have spoken we are free.

$\S 6$. It would appear, then, that by the decision, simply as a decision, we really need not feel ourselves or our Church in any degree bound or committed. It may be a great scandal and a bad precedent, but no man is pledged as a Churchman or as a clergyman to abide by it, and therefore no man need think of retiring on account of it. But there is one circumstance connected with it which yet requires grave consideration; it presents, iudeed, as far as I see, the only real difficulty of the case, in the view of a conscientious Churchman, knowing and wishing to hold by the rules of antiquity. That circumstance is the share which the Metropolitan has had, and is likely to have, in the whole transaction; and the difficulty which it raises is incurred already: we have not to wait for it until some fresh appeal shall have been dealt with: we have been burdened with it ever since the first solemn declaration of the Court at Bath in the case of Archdeacon Denison. It is simply this: that if there be any soundness in the statements and arguments set down above, the proposition of the Court touch- 
ing worship in Holy Communion would seem, even by the Crap. v. existing law of the English Church, to be heretical, or verging on heresy; and of course the question might occur, Can Christians knowingly go on in communion with a spiritual superior who has publicly so committed himself, and not be partakers of the ill? This question I should answer, without hesitation, in the affirmative, and that for reasons strictly ecelesiastical. I will endeavour to explain, as briefly and clearly as I can, the grounds both of the difficulty and of the solution.

For the prima facie suspicion of heresy: the measure and extent of that evil, as is well known, are legally determined among us by the statute, 1 Eliz. i. 56 , where it is ruled that persons commissioned by the Crown to determine ecclesias. tical causes "shall not in any wise have authority or power to order, determine, or adjudge any matter or cause to be heresy, but only such as heretofore have been determined, ordered, or adjudged to be heresy, by the authority of the canonical Scriptures, or by the first four general Councils, or any of them, or by any other general Council wherein the same was declared heresy by the express and plain words of the said canonical Scriptures, or such as hereafter shall be ordered, judged, or determined to be heresy by the high court of parliament of this realm, with the assent of the clergy in their convocation;" and "it hath been since generally holden, that although the High Commission court was abolished by the statute 16 Chas. I. c. 11, yet those rules will be good directions to ccclesiastical courts in relation to hercsy ${ }^{0}$."

Now the third Ecumenical Council, that of Ephesus, A.D. 431, gives the full authority of the Chureh to the following paragraph of the remonstrance sent to Nestorius a little before by S. Cyril and the Synod of Alexandria p.

"And there is another point which we must of necessity add; how that, setting forth the death after the flesh of the Only-begotten Son of God, that is, Jesus Christ, and confessing Ilis resurrection from the dead, and ascension into the heavens, we celebrate in the Churches the unbloody

- Burn's Eecl. Law, ii. 277. 5th ed.

r § vii. ap. Routh, Opusc. ii. 25. 
Crap. V. Sacrifiec. And thus we draw nigh to the mystieal Eucharists, and are sanetified by becoming partakers of the holy Flesh and the precious Blood of Christ the Saviour of us all. And not as common Flesh do we receive it, (God forbid!) nor yet as that of a Man sanctificd, and united unto the Word as having one and the same dignity, or as having reecived God to dwell in Him, but as truly life-giving, and the very Flesh of the Word Himself. For being, as God, in His nature, Life, in that He became One with His own Flesh, He manifested it to be life-giving. So that, although IIe say to us, "Verily, verily I say unto you, Except ye cat the Flesh of the Son of MLan, and drink His Blood,'-we are not to infer that it (like the rest) is the flcsh of a man, one of those who are such as we are; (for how shall the flesh of a man be life-giving, according to its own nature?) but that it has truly become the very own Flesh of Him who for our sake both became and is entitled as well a Son as a Manq."

Here it is plain, first, that the Council, adopting the phraseology of the Liturgy then in use at Alexandria, gives distinct sanction to the doetrine eontained in that and all the ancient Liturgies, of the unbloody Sacrifice offered in all Churches eontinually. Next, that it attributes our partieipation of Christ's Body and Blood, and our consequent sanctification, not to the whole action, including the praycrs and the rest, but to that which we do when we draw nigh to that which has been sacramentally blessed, and partake of it. Thirdly, that what we so draw nigh to receive and to partake of is not "common flesh," (God forbid!) but the "very own Flesh of the Word, Who, as God, being by nature Life, becanse He had made Himself one with His own Flesh, declared it to be life-giving." It is for those who deny the Real Prescnce, and forbid adoration, to reconcile these sayings, if they can, with their own views; or clse to shew some reason why they are not to be accounted so far heretical, according to the standard of heresy in the Church of England.

$\$ 7$. Consider, again, in connection with the foregoing, what follows, and observe how it is sanctioned; it is not a statement made incidentally with a view to establish some-

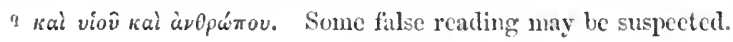


thing else, but was regarded by the Ecumenical Council as Cirap. v. so necessary a portion of our holy faith, that they guarded it with a special anathemar ${ }^{r}$ : "If any one confess not the Flesh of the Lord to be life-giving, and the very own Flesh of the Word Himself who is of God the Father, but [regard it] as belonging to some other beside Him, howerer elosely knit unto Him in dignity,-i. c. as having simply received an indwelling of the Deity, and not rather as life-giving, (to repeat the expression,) because it hath become the very own Flesh of the Word who hath power to quicken all things," (or "to make all His living progenys,"-" let him be anathema."

Observe that the life-giving quality is declared to depend on Its being "the very Flesh of the Word who hath power to quicken all things;" which implies that It is life to us not simply by Its merit as a Sacrifice on the Cross, but also by a real participation of It on our part. That Flesh, the Council means, which we approach and partake of in the Eucharist: no one, if he fairly compare the two passages, can avoid secing this. Or if there were any doubt, it would be settled by the use of the same phrase, "the mystic Eucharist," in the following dictate of S. Cyril ${ }^{t}$ : "I hear that some affirm that the mystical Eucharist avails not for sanctification, if any relic of it remain unto another day. But in so saying they are beside themselves. For Christ is not estranged [therefrom], neither will His holy Body admit alteration. But the power of the blessing, and the life-giving grace, do therein continue." The particular idea denoted by that word "objective" could scarce be set forth more distinctly. Can we help recognising it, when the same phrase, "mystic Eucharist," is employed by the Council itself, over which the same S. Cyril was presiding, and in a document of which it is impossible to doubt that he was himself the author? And this document has been in such sort adopted by the Church of England, as that any contradiction of it is enacted to be positive hercsy.

× Ibid. $\$$ xi. p. 32 .

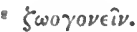

' Èp. ad Calosyrium, Op. t. vii, 365 I3. ed. Aubert.: cf. Cosin's Works, v. 130. 
Cris. V. $\S 8$. Nor may it be omitted that the first Nicene Council so far encourages the same notion, as not only to call the holy Eucharist in three several canons a Gift and an Offering, but also to imply that the giving and receiving of it is giving and receiving the Body of Christ ${ }^{u}$. In the fifth canon they say, (and surely it is an enactment not unseasonable to be brought just now to our recollection,) - "At the provincial synod twice in the year inquire into the causes of the excommunicate, lest some narrowness of mind or party-spirit, or other uncomfortable feeling, should have caused the exclusion; and let one of the synods be holden before Lent, that all such ill-temper being done away, the Gift may be offered pure unto God." In the eleventh, certain penitents are directed, without offering, to communicate in the prayers only. The eighteentl runs thus: "It hath come before the holy and great synod, that in some places and cities the deacons give the Eucharist to the presbyters, a thing transmitted to us neither by canon nor custom, that such as have no authority to offer, should give to those who offer the Body of Christ. And of this, too, we lave been informed, that certain of the deacons approach the Eucharist even before the Bishops. Wherefore, let all this be done away. . . . Let them receive the Eucharist in their own order, after the presbyters, at the hands either of the Bishop or the presbytcr." Here is a distinct recognition of the Eucharist, as a sacrifice in which the Body of Christ is offered by Bishops and presbyters, and cannot be offered, in the same sense, by deacons and laymen.

$\$ 9$. No one who really reflects upon these sayings of the great councils, and is at all aware of the mass of undesigned testimony, diffusing itself through all antiquity, to the same effect, can doubt what sort of a decree would have been passed at Nicaea or Ephesus, had the doctrine of the Eucharist required synodical assertion in those days. But whether it be that the sacramental system does not require to be doctrinally known in order that its benefits may be received, any more than a person need be able to analyze what he eats and drinks before he can have it for "food and gladness,"

u Ap. Kouth, Script. Eccl. i. 373, 377, 381. 
or for other eauses unknown to us; it pleased Providence Crap. v. that the Church should enter on its era of sad division

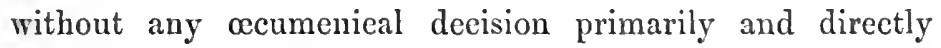
pronounced on that subject. And therefore that portion of Christ's truth has not come down to us in distinct dogmatical assertions guarded by anathemas, as the statements concerning the Trinity and Incarnation have. And it is consequently a more adventurous thing, and more largely partaking of the boldness of private judgment, to denounce any person as a heretic in respect of the former class of errors. It is not so plainly our duty to withdraw from his communion, as it would be if he had been distinctly excommunicated by the Church. Materially he may be in heresy, but formally he is not yet so,-a distinction aeknowledged by all theologians. "Simple error is not heresy, without the additon, 1 . of something in the matter of it, viz. that it take place in somewhat appertaining to the faith; and, 2. of something in the erring person, i. e. pertinacity, which alone makes a heretic. And this pertinaeity arises from pride; for it eometh of great pride, when a man prefers his own sense to the Truth Divinely revealed." And S. Augustine says, "Though men's opinion be false and perverse, yet if they maintain it not with any obstinate wilfulness; and especially if it be one which they have not daringly and presumptuously engendered for themselves, but have received it of parents misled and fallen into error; and if with careful anxiety they are seeking the truth, and are ready, as soon as they have found it, to receive eorrection; sueh are by no means to be accounted among hereticsx." "Because" (as Aquinas, quoting the passagc, adds) "they have no choice, aí $\rho \in \sigma \nu$, - no set purpose, - of contradieting the doctrine of the Church. In this way," (he proceeds to say,) "certain doctors appear to have differed, eren in some things appertaining to the faith, which had not yct been determined by the Church. But after they had been determined by the authority of the universal Church, if any one kept obsti-

- S. Tho. Aquin. De Malo. qu. viii. Art. i. ad $7^{\text {mumb }}$ t, xv. 165 . ed. Venet. 1781. x Ep. xliii. 1. t. ii. p. 67. el. Bened. Antwerp, 1700. 
Crap. v. nately resisting such an ordinance, he would be accounted a heretic y."

In the case before us, the determination of the whole Church is so far less unequivocal than it might be, in that it has never been sealed with an anathema by an CEcumenical Council. Nor is there any proof of its having been so distinetly set before those who have denied it, that they can be rightly and at once accused of heretical pravity in resisting it. And even if they might, that were no excuse for separating from the hundreds of thousands of simple Christians who go on believing our Catechism and partaking of our Eucharist, with or without any definite perception of the doctrine of the Sacraments, vital though it be. "For" (to quote again the same author") "the simple are not condemned as heretics for not knowing the Articles of the faith, but because they obstinately maintain things contrary to those Articles; which they would not do, if they had not their faith corrupted by heresy."

In sum: heretical as this or any similar decision may appear to a well-instructed private Christian, it cannot, under existing circumstances, so taint with heresy those who pronounce or favour it, as to render it his duty to break communion with them, and with all, sound or unsound in faith, who abide in the same body with them. It might and would be his duty, had they been pronounced heretics by sufficient authority; but such is not now the case. For example: were there now a Chrysostom or an Aquinas in the Roman Church, he might perchance upon good grounds seriously apprehend that the recent decree touching the Immaculate Conception of the Blessed Virgin does in fact promulgate a material heresy, and that a true CEcumenical Council, were such an one cver to mect and decide upon that doctrine, would assuredly condemn it with an anathema. But it does not follow that a person so convinced ought to withdraw himself from the present Roman Catholic Communion. It might be his duty to make such a profession of his faith as would probably involve him in scrious ecclesiastical penalties. 
But excommunication or deprivation incurred for conscience' Crap. V. sake is one thing, voluntary separation is quite another thing. The application to our own case is evident.

There are, indeed, instances in Church history of private persons, lay or clerical, refusing to communicate with heresiarchs; as Eusebius of Dorylæum, and others separating themselves from Nestorins, in the beginning of the movement which led to the Council of Ephesus : but they did not thereby break communion with the mass of believers at Constantinople; and it seems not to have been so much from an apprehension of contracting the heretical taint from him, as because such separation was the received mode in that time of bringing such questions to a legitimate issue: as if onc should say, "Either he must be excommunicated or I." It is no longer so, now that the holy discipline is so generally, alas! in abeyance.

$\S 10$. But is there, then, no remedy? nothing for clergymen or faithful laymen to do, who may feel with the whole Church for so many ages, that he who touches the doctrine of the Real Presence after Consecration, touches-to use sacred words-the very "apple of their eye,"-whether it be by prohibition of worship or in any other way? Yes, surely; they have first and chiefly hearts to lift up night and day in prayer to the Most Holy Trinity, and they lave the commemorative Sacrifice of their Lord, in union with which to present their intercessions. As towards men they have tongues and pens, wherewith to protest and appeal; they have influence with more or fewer of their brethren; they have more or less substance, of which they may give to such as are suffering in any way for the same truth, (of whom not a few may be found, if they are well looked after). And in the present instance there is something yet more to be done, by all subscribers to the Articles at least; their protests and appeals need not be mere words, as on other occasions the like may have appeared; they may be so worded, and so publicly notified, as to make them liable to the same molestations and penalties which others for the same teaching have incurred ${ }^{\text {a }}$. Such sayings are real doingss, and if God

a See note at the end of the book. 
Char. V. give them grace to utter them not rashly or in the way of challenge, but in the serious discharge of a painful duty, they may be blessed, if trouble ensuc, with somewhat of the peculiar blessing of Christ's confessors.

$\S 11$. One word more to point out why the way of Appeal as well as Protest is recommended. Protest, strictly speaking-i.e. a mere 'solemn declaration against a thing'-appears to be the course of those who feel themselves aggrieved, but know of no legal remedy. But to appeal, taken also strictly, is to apply to another, a superior judge; it assumes that there is a grievance, but supposes also a constitutional corrective. A protest, as such, simply relieves the mind and conscience of those who take part in it; an appeal adds to this a call upon certain others who are supposed to have power to redress the wrong.

A protest in any juridical matter supposes the final authority to have spoken; an appeal, of course, supposes the contrary.

For which reason, among others, it seems matter of regret that the term protestant rather than appellant was adopted by those who, not intending schism, were cut off from the Church of Rome in the sixteenth century; especially as the former term arose from the mere political accident of their representatives forming the minority in the Diet of Spires, 1529, whereas the latter would liave kept in mind Luther's appeal long before to a general council: a much more legitimate and ecclesiastical ground to stand on, were it only that by simply protesting we do in some scnse admit the paramount authority of Rome, by appealing we assert Rome herself to be under authority.

However, in our own position-I mean, the position of English Churchmen-it seems to be of the very last importance that we should keep in our own minds, and before all Christendom, the fact that we stand as orthodox Catholics upon a constant virtual appeal to the ecumenieal voice of the Churcl, expressed by the four great Councils, and by general consent in all the ages during which she continued undivided. And if that voice be disputed, is there any conceivable way of bringing the dispute to an issue, except only another true (Ecumenical Couneil, when such by God's grace 
may be had? In the meantime, what can we do but con- Crap. V. tinue as we are in those points of our creed which other portions of the Church dispute, (unless we can be proved to be wrong:) not denying their life and catholicity, but maintaining our own, with submission to the whole Church? 'The position may be called unreal or chimerical, but it is that which has becn claimed for the Church of England by two great men (to mention no more) whose names may as fairly as any be taken to represent the great schools or sections in this Church: Cranmer, when drawing towards his martyrdom, and Bramhall in his exile, expressly asserting not simply the truth, but the Catholicity of the English Church. And they were not either of them persons apt to take up with a chimcrical, unreal view.

Nay, the question may be well asked-much more easily asked than answered-whether, in the present divided state of Christendom, all who believe in the holy Catholic Church must not in reality, however unconsciously, be going on under this very appeal : at least, as against other claimants? The Greek will say, "I go by the voice of the present Church diffusive;" the Latin, "I go by the infallible voice of the See of S. Peter;" the English, "I go by what has been held fundamental every where, always, and by all :" but who is to decide between them, which of these measures is right? Yet all, one may hope, would agree to defer to the decision of such a Council as has been specified, were it obtainable. It is our common position; and we in England have so much the more reason to acquiesce in it, as it does not force us to "unchurch" (as it is termed) either of the other great sections of Christendom, as they do mutually one another and us.

Many a devout and loving heart, I well know, will rise up against this view of our case. To be on this conditional, temporary footing, will strike them as something so unsatisfactory, so miserably poor and meagre, so unlike the glorious vision which they have been used to gaze on of the one Catholic Apostolic Church. And poor, indecd, and disappointing it undoubtedly is, but not otherwise than as the aspect of Christianity itself in the world is pool 
Cияг. V. and disappointing, compared with what we read of it in the Gospel.

Men will not escape from this state of decay by going elsewhere, though they may shut their eyes to the reality of it. Rather, whatever our position be in the Church, since Grod Almighty has assigned it to us for our trial, shall we not accept it and make the best of it, in humble confidence that aceording to our faith it will be to us?

This (please God) is the way of truth and peace, and therefore in it we may hope for a blessing; the rather, if it should prove to be the way of the Cross also. But to engage oneself, by a strong act of the will, to the whole system of a body new to us, not upon the proper evidenee of that system, but because some in temporary authority among ourselves have denied our holy doetrine-this has something in it so very unreal, that it can hardly agree with truth; and so like ill-temper, that it gives but a bad omen for peaee. This is said, not from any special apprehension of such evil in store for us now, but from sad remembrance of what has occurred on former misinterpretations of our Church's doctrine.

But we may hope for better things. If only two kinds of people would be patient with one another-those who have hitherto worshipped Christ in the Eucharist undoubtingly, and those who for vague fear of certain errors have shrunk from owning, even to themselves, that they worshipped Him; if both sorts would pray and strive to be helped to take simply the plain words of Holy Scripture and the Church, as they do in respect of other mysterics;-then this Sacrament of peaec, ceasing to be to believers a Sacrament of contention, would be free to work its Lord's work among men: being, indeed, that wonder-working Fire which He came to kindle on the earth, of power to transform and subdue all to itself.

Should what has been here set down contribute towards that blessed end but in one single instance, God be thanked! it will not have been written in vain. 
NOTE on c. v. $\S 3,10$, p. 163, 175.

As an exemplification of the course here reeommended, I subjoin, 1. a copy of a Protest and Appeal, occasioned by the Primate's Decision in the Court at Bath; 2. a letter written in explanation of that paper by some of those who signed it, but suppressed at the time in deference to the scruples of others, who considered themselves implicated in it in a way which they thought unadvisable.

\section{Protest and Appeal. (185̌6.)}

" $W_{E}$, the undersigned, Priests of the one Catholic and Apostolic Church, called by God's Providence to minister in the Province of Canterbury, according to the Book of Common Prayer, do hereby, in the Presence of Almighty God, and in humble conformity with the tenor of our Ordination Vows, as we understand them, make known and declare as follows :-

1. We believe (in the words used in the Book of Homilies) that in the Holy Eucharist we "receive the Body and Blood of our Lord Jesus Christ under the form of bread and wine;" and with Bishop Cosin, "that upon the words of Consecration, the Body and Blood of Christ is really and substantially present, and so exhibited and given to all that receive it; and all this, not after a physieal and sensual, but after an heavenly and incomprehensible manner;" of which statement, Bishop Cosin says, "it is confessed by all Divines."

2. We believe, in the words of Bishop Ridley, "that the partakinge of Christ's Bodie and of His Bloude unto the faithfull and godlie, is the partakinge and fellowship of life and of immortalitic. And, again, of the bad and ungodlic receivers, St. Paul plainlie saieth thus: 'He that eateth of this breade and drinketh of this cuppe unworthilie, he is guilty of the Bodie and Bloude of the Lord. He that eateth and drinkcth unworthilic, eateth and drinketh his own damnation, because lie estecmeth not the Lord's Bodie;' that 
is, he receiveth not the Lord's Bodie with the honoure whiche is due unto Hym." Or with Bishop Poynet, "that the Eucharist, so far as appertains to the nature of the Sacrament, is truly the Body and Blood of Christ, is a truly divine and holy thing, even when it is taken by the unworthy; while, however, they are not partakers of its grace and holiness, but eat and drink their own death and condemnation."

3. We hold, with Bishop Andrewes, that "Christ IIimself, the inward part of the Sacrament, in and with the Sacrament, apart from and without the Sacrament, wheresocver $\mathrm{He}$ is, is to be worshipped." With whom agrees Archbishop Bramhall: "The Sacrament is to be adored, says the Council of Trent, that is, (formally,) 'the Body and Blood of Christ,' say some of your authors; we say the same: "the Sacrament,' that is, 'the specics of bread and wine,' say others; that we deny."

We therefore being convinced,

1. That the doctrine of the Real Presence of "the Body and Blood of our Saviour Christ under the form of Bread and Wine" has been uniformly held as a point of Faith in the Church from the Apostolic times; and was accepted by General Councils, as it is also embodied in our own formularies;-

2. That the interpretation of Scripture most commonly held in the Church has been, that the wicked, although they can "in no wise be partakers of Christ," nor "spiritually eat His Flesh and drink His Blood," yet do in the Sacrament not only take, but eat and drink unworthily to their own condemnation the Body and Blood of Christ, which they do not discern ;-

3. That the practice of worshipping Christ then and there especially present, after Consecration and before communicating, has been common throughout the Church :-

- And moreover that the Thirty-nine Articles were intended to be, and are, in harmony with the Faith and Teaching of the Aneient Undivided Church ;-

Do hereby protest earnestly against so much of the opinion of his Grace the Archbishop of Canterbury, in the case of Ditcher $v$. Denison, as implies, directly or indirectly, that 
such statements as we have cited above are repugnant to the doctrine of the Thirty-nine Articles;-

And we appeal from the said opinion, decision, or sentence of his Grace, in the first instance, to a free and lawful synod of the Bishops of the provinee of Canterbury; and then, if need be, to a free and lawful syuod of all the Churches of our communion, when such by God's mercy may be hat.".

2. Letter in explanation of the foregoing.

"IT having been given out that those who signed the Protest and Appeal against the recent decision on the Doctrine of the Holy Eucharist may probably end in forming a Nonjuring Church, will you allow us to state through your paper, that we have no such intention or thought. The object of that declaration was to liberate our own consciences.

We believe, in their most literal and fullest sense, every word of the Articles, on the ground of which Archdeacon Denison has been condemned. We camnot see how the doctrines for which he has been condemned can be fairly brought under the Articles. We are convinced, that they are points upon which the Church of England has not decided; and that those who have condemned him, have proceeded on grounds foreign to the Articles. They have brought meanings into the Articles, not out of them. Still, since we believe that which the Archbishop and his Assessors have condemned as contrary to the Articles, it became matter of honesty to avow it. We are in a place of sacred Trust. If we voluntarily retire from our place, we betray our trust; if we continue in our place, saying nothing, we seem to betray it. Either way there is grievous scandal. The only course open to us is, publicly to apprise those in authority over us, that we camnot obcy then in this, and to. go on as before, leaving it to them to interfere with us, or no, as they may think fit. It was on this view of our duty that we signed that Paper. Our subseription to the Articles is lonest in itself, for we believe them in the only sense of which we can see them to be capable. But we did not feel 
it honest to hold a belief which had been condemned as contrary to the Articles, and not to avow that we held it, and make ourselves liable to the consequences.

The bcing of the Church of England we believe to be perfectly unaffected by this decision, grievous as the result of it may be in respect of her well-being. The sentence of an Archbishop's Court may make an Act penal; but the sentence of one man cannot bind the conscience. Prosecution after prosccution can but deprive individuals. Nothing less than the voice of the Church can make any clecision the judgment of the Church; and nothing but the judgment of the Church (in fact, a new "Article of Religion") can limit, as now proposed, the meaning of the present Articles. If the Church of England should will to condemn what hitherto she has not condemned, she must do it by a distinct Act.

We know there are some who wish us to be removed. But we do not, please God, intend to do their work for them by withdrawing. Even should we be deprived, we should hope not to be silenced, nor degraded, nor excommunicated. Meantime, in full conviction that we teach only what the Church sanctions, or at any rate allows, we shall go on teaching as long as we are permitted to do so. 'Through God's good Providence we have had our several spheres of duty assigned to us. If it be His Will, He will help us cheerfully to exchange them for others. But it will be His doing, not ours. We hope to know His Will best, by waiting for it." 


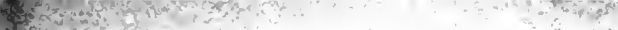


